\title{
Prescribing the Profession: Representations of Medical Professionalization Debates in American Literary Forms, 1830-1940
}

Jeffrey Wayne Yeager

West Virginia University, jwyeager@mix.wvu.edu

Follow this and additional works at: https://researchrepository.wvu.edu/etd

\section{Recommended Citation}

Yeager, Jeffrey Wayne, "Prescribing the Profession: Representations of Medical Professionalization Debates in American Literary Forms, 1830-1940" (2020). Graduate Theses, Dissertations, and Problem Reports. 7605.

https://researchrepository.wvu.edu/etd/7605

This Dissertation is protected by copyright and/or related rights. It has been brought to you by the The Research Repository @ WVU with permission from the rights-holder(s). You are free to use this Dissertation in any way that is permitted by the copyright and related rights legislation that applies to your use. For other uses you must obtain permission from the rights-holder(s) directly, unless additional rights are indicated by a Creative Commons license in the record and/ or on the work itself. This Dissertation has been accepted for inclusion in WVU Graduate Theses, Dissertations, and Problem Reports collection by an authorized administrator of The Research Repository @ WVU.

For more information, please contact researchrepository@mail.wvu.edu. 


\title{
Prescribing the Profession: Representations of Medical Professionalization Debates in American Literary Forms, 1830-1940
}

\author{
Jeffrey W. Yeager \\ Dissertation Submitted \\ to the Eberly College of Arts and Sciences \\ at West Virginia University \\ in partial fulfillment of the requirements for the degree of \\ Doctor of Philosophy \\ in English
}

\section{Timothy Sweet, Ph.D., Chair \\ Dennis Allen, Ph.D. \\ Cari Carpenter, Ph.D. \\ Michael Germana, Ph.D. \\ Paul Jones, Ph.D.
Department of English
Morgantown, WV

2020

Keywords: American literature, gothic fiction, American Realism, American Naturalism, medical professionalization 


\begin{abstract}
Prescribing the Profession: Representations of Medical Professionalization Debates in American Literary Forms, 1830-1940.

Jeffrey W. Yeager

This dissertation traces the debates concerning the professionalization of medicine in America across the $19^{\text {th }}$ - and well into the $20^{\text {th }}$-century and explores how the debates concerning professionalization in any given moment affected popular literary forms. Using Fredric Jameson's The Political Unconscious as its theoretical framework, this dissertation's chapters on the gothic, realism, naturalism, and satire trace each mode's dominant hegemonic position on this issue while showcasing dissenting voices across this century-long discourse. This project's methodology is centered in the New Historicism. Unlike other projects before it, this dissertation focuses primarily on the historical problem of state laws either regulating or deregulating the professionalization of medicine; however, it also emphasizes close attention to literary form as it traces the dominant and dissenting voices of these popular literary modes. Authors surveyed across this project include Nathaniel Hawthorne, Edgar Allan Poe, H.P. Lovecraft, William Dean Howells, Elizabeth Stuart Phelps, Sarah Jewett, Annie Meyer, S. Weir Mitchell, Charlotte Perkins Gilman, Frank Norris, John Steinbeck, and Sinclair Lewis.
\end{abstract}




\section{Table of Contents}

Acknowledgements....................................................................................................................

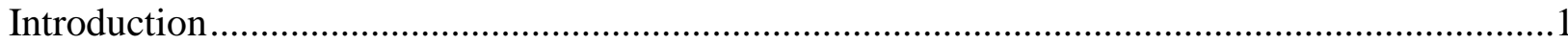

Chapter 1: The Philosopher Physician: Gothic Fiction and the Deregulation of Medical Professionalization in Jacksonian America

Chapter 2: The Politics of Medical Professionalization \& Realist Form: A Study of Howells, Phelps, and Jewett

Chapter 3: 'Ain't I a Doctor?': Medical Professionalization \& the Disenfranchisement of the Individual in Selected Texts of American Literary Naturalism .....

Chapter 4: A Return to the Philosopher Physician: the Satiric Realism of Sinclair Lewis's Arrowsmith

Conclusion: Contemporary American Medical Debates \& Literary Form. 


\section{Acknowledgements}

I would like to start by thanking my chair, Dr. Timothy Sweet, for reading over countless drafts of my chapters and for helping to facilitate the growth of my ideas as the dissertation progressed. I appreciate the patience Tim showed during this long process, and I am grateful for his insightful feedback.

This project originated in a term paper I wrote in Paul Jones's seminar on American Realism and Naturalism at Ohio University in 2011 during my M.A. program. I am grateful to Paul for seeing this project all the way to the end as a committee member who strengthened the work with his feedback.

I also extend thanks to my other committee members: Dr. Dennis Allen, Dr. Cari Carpenter, and Dr. Michael Germana. I particularly want to extend thanks to Dennis for providing chapter by chapter feedback.

Considering this project is for a Doctor of Philosophy degree, and considering philosophy's etymology means "love of knowledge," I would be remiss to not mention several educators who shaped my love of knowledge over the years. Some names I want to mention whom I have not yet included: Dr. John Baker, Dr. Jonathan Berkey, Dr. Robert DeMott, Dr. Marsha Dutton, Dr. Paul Kane, Dr. Carol Manzione, Dr. Joseph Manzione, Dr. Thomas McKenna, Mr. Benny Mills, Dr. Gabriel Rieger, Dr. Elizabeth Roth, Mr. Larry Stewart, and Dr. Robert Tallaksen. I would not be here without having learned from all of you. Thank you.

I cannot express my gratitude enough to the West Virginia University Department of English for providing me generous support through a teaching assistantship, two fellowships, and meritorious tuition waivers. I also want to thank Southern West Virginia Community and Technical College, especially Dr. David Kommer, for taking a chance on employing me full-time before I finished my dissertation. Without that position, it would have proven difficult for me to finish this project.

I would not be here without the support of my family: my dad Jeff, my mother Linda, and my brother Matt, whose encouragement inspired me to continue to the end. 


\section{Introduction}

Compared to almost every other nation in the Western World, America has had a unique, complicated relationship with its medical profession. Ideas of American democracy naturally conflict with the ethos of a medical profession founded on its knowledge and privileges. This conflict can be traced to the early decades of the American Republic to the current moment as Americans debate how to manage the healthcare industry while also considering the needs of individual patients. Should a greater amount of freedom be given to Americans today who seek alternatives from a medical profession that is perceived as self-serving? Over the past decades, historians of the medical profession have traced the problem of medical professionalization across the nineteenth-century to the present; however, even though a plethora of fictional texts exist in American literature that represent the medical profession, a cultural history of Americans' complex relationship with the medical profession through literature has not been completed. This dissertation seeks to fill this gap in knowledge.

This work, to some degree, asks the question: to what degree did American prose that featured plots about medical professionalization represent the 'real' with regards to varying stakeholders? If writers in differing literary modes took up the subject of something so political, to what extent do the structures of these modes affect the works' subtext? Does the structure of the modes force certain attitudes to arise, or do writers have considerable flexibility to innovate various literary forms by representing such a divisive theme? Furthermore, considering political works can be read as lacking universal appeal stretching across generations of readers, readers who may not deal with said problems decades or centuries in the future, how can a work written about something as specific as medical professionalization be aesthetically pleasing? Regarding 
literary activism, what can these literary texts, and the way they are structured, offer us today in an era as divided by class as the latter-nineteenth century?

This dissertation argues that to make sense of the proliferation of fiction of the medical profession in the nineteenth century, a need to contextualize popular literary modes with the politics of professionalization exists. As a widespread social movement, medical professionalization divided Americans in the nineteenth century as political arguments concerning class conflict became widespread; should medical practitioners have a medical degree and standards for a profession, or are those standards elitist? The need arises then to trace and question the politics of literary form, and this raises the question: as products of their time and place, to what extent do literary forms share complicity with various social classes in a social debate centering on class politics? To what degree are literary forms complicit with political movements and audiences? This also raises the question: if literary forms have political functions, what degree of freedom do writers who resist the form's politics have in innovating their representations beyond the limitations imposed by the mode's most prominent voices? This dissertation thus argues that all these literary forms have a political function molded by the politics of powerful individual authors; however, literary forms do offer considerable freedom for those with political difference to innovate these structures further.

This project thus seeks to historicize discourses about literary form in conjunction with those on medical professionalization to merge two narratives together, the historical narrative about professionalization with the narrative of the literary history of the rising or waning popularity of different American literary forms. Considering every mode surveyed represented this theme, this project's goal is thus to contextualize literary form with these political arguments to discern what function these texts had on their readers' political inclinations. It is this project's 
goal to illustrate how the political function of each form changed depending on the discourses started by popular voices within each mode while also recognizing that clever outside voices could manipulate the aesthetic boundaries of the form to fulfill their own political agendas. It is through this method that the project also illuminates the aesthetic value of these works. This project contends that writers who manipulate political conventions in complicated or self-aware ways are deserving of greater aesthetic appreciation and further study.

\section{Historical Narrative Regarding Medical Professionalization:}

Historians have long discussed not only the professionalization of medicine but also several other professions as well: law, dentistry, plumbing, and even academia became professions by the latter half of the nineteenth century as certifying boards excluded outsiders from entry. By its nature, professionalization is meant to stabilize various middle-class professions and give them an epistemic legitimacy in the eyes of the public; however, professionalization also makes entry into said professions difficult and rigorous. Robert Wiebe, in his history of the Progressive Era, notes that "the specialized needs of an urban-industrial system came as a godsend to a middle stratum in the cities. Identification by way of their skills gave them the deference of their neighbors while opening natural avenues into the nation at large" (113). Furthermore, this new middle class forged itself by fiercely defending its interests through "increasingly formal entry requirements into their occupations (that) protected their prestige through exclusiveness" (113). As a result, when the issue of professionalization arises in fictional texts from a variety of literary modes, the implications of what it means to be part of the middle-class and how to enter the middle-class are at stake, and each mode has its own unique political inclinations. 
The issue of professionalization became a significant enough problem in Jacksonian America to warrant a nationwide attempt, mostly at the state level, to deregulate medical entry requirements and to democratize medicine to the point where patients could choose several options: homeopathy, spiritualism, mesmerism, and phrenology to name but a few (Dunn 2-3). This inclination originated in some degree from the ethos of Jacksonian democracy, as Jackson himself felt an extreme disdain for professionals whom he deemed as aristocratic elites as he called for a "stand against all new grants of monopolies and exclusive privileges, against any prostitution of our Government to the advancement of the few at the expense of the many, and in favor of compromise and gradual reform in our code of laws and system of political economy" (Sellars 326). While allopathic practitioners practiced the same heroic medicine as the likes of physicians like Dr. Benjamin Rush a generation before them, they, without any professional organizational apparatus, found themselves at the mercy of an American public who in general felt a profound sense of skepticism about practitioners whom they deemed as elites. They were deemed to be elites because the physician's reliance on elite knowledge like Latin “demarcated knowers from non-knowers," as the "language of medicine signified membership in an elite community. If one could not participate in such Latinate discourse, one was not meant to meddle in medicine" (Whooley 46).

In general, most at stake was the patient's sense of feeling marginalized by these practitioners, as a general anxiety pervaded the American public that these practitioners care more for knowledge for knowledge's sake than the needs of the patient. This trope originated early in the Nineteenth Century in gothic fiction: some significant debt is owed to British literature with Mary Shelley’s Frankenstein, and then American authors Nathaniel Hawthorne and Edgar Allan Poe took up the subject. As the century progressed, the medical profession 
again regained its footing, but patients still distrusted whether the profession had the best interests of patients in mind; homeopathy and others remained as popular alternatives. In looking at the profession from the profession's point of view, historians have provided a succinct history; however, literary and cultural history can better help us understand the perspective of patients during this historical trajectory.

Several factors caused the reemergence of the profession by the end of the century. Just before the Civil War, allopaths united into a professional apparatus, the American Medical Association; similar healthcare professions, like dentistry and veterinary medicine, also followed suit with the creation of these organizations. Historian Owen Whooley has noted the significance of these organizations, as they not only "institutionalized communities of knowers" but also marshaled "resources to promote the production of knowledge along certain epistemological lines" (83). Once allopathy united into this guild, the organization could unilaterally proclaim other practitioners as quacks and bar entry into the profession, thus giving the organization a legitimacy in the eyes of the public. The act of believing this practice was the best possible medical solution, and uniting around that belief, gave allopathy a sense of credibility. Homeopathy and other alternative practitioners did not unite into a common organizational apparatus until long after allopaths did so, who by that time had long solidified their status as the leading scientific authorities.

Another reason why allopathy gradually returned as the leading medical apparatus was the fact that under this apparatus, they made the right decisions about what new medical advancements to endorse along with the methods that came with those advancements. Americans did not innovate in the medical field in the latter nineteenth-century; allopathy followed and accepted the advances of German bacteriology. Following the discovery of the cholera microbe 
by Robert Koch, American allopathy framed his discoveries as a discovery of the profession:

"Koch become an allopath, and his finds became entangled in the epistemic contest between regulars and homeopaths in the United States" (Whooley 179). With their patient-centered ontology, homeopaths did not embrace the new trends toward bacteriology, which was perceived as a cold and impersonal means of care; instead, they embraced the empirical, trial and error methods.

The Civil War also helped to shift allopathy back into public prominence. Along with the creation of the American Medical Association, no other factor proved to be more effective than the war. During the war, the Union Army faced a critical shortage of physicians, so Senate Bill 188 was passed into law by Lincoln allowing for homeopaths to practice in the Army. However, lobbyists from the AMA successfully petitioned the Army Medical Board to not allow homeopaths or other alternatives, and despite the law being passed, it was not enforced considering larger issues were at stake. This prevented homeopaths from achieving equal status and claims to legitimacy based on their lack of resources alone (Whooley 104-5).

Despite allopathy's success at professionalization, a large marketplace nonetheless existed for alternative healers as concerns about allopathy's lack of concern for the patient persisted. Homeopaths found a niche in urban centers as wealthier patients tended to favor the more patient-centered methodology (144). Homeopaths also actively participated in city-wide sanitation efforts to combat disease. Despite the story of allopathy regaining its professional legitimacy, the issue nonetheless divided many Americans.

As the century ended, most states enacted professionalization laws again demanding a minimum amount of education and experience; everyone who did not meet that criteria lost their ability to practice. This caused a large amount of public outrage as not only did some 
practitioners ignore this law but also the issue became so prominent that it reached the Supreme Court in Dent vs. West Virginia (1889). In 1910, the American Medical Association commissioned Abraham Flexner to write a report surveying medical schools; whoever received stellar reviews had funding from the likes of Andrew Carnegie flow their way. Flexner advocated for higher standards, like a four-year degree before entering medical schools, standards which alienated alternative practitioners. Flexner's new standards helped to bankrupt homeopathic schools; in the twenty-five years after his report, homeopathic schools dwindled from twenty-five to two (Whooley 216). Flexner's Report effectively ended the medical professionalization debates; however, the long history of these debates has left a lasting mark on the medical profession as many people remain skeptical and distrustful of it today; this dissertation examines several texts both at the end of this trajectory as well as surveying contemporary representations to showcase how this topic remains in the cultural consciousness of Americans.

\section{This Dissertation's Role in the Larger Scholarly Conversation:}

This dissertation seeks to write a cultural history of sorts on how the problem of medical professionalization was represented in literature. In doing so, this project seeks to also draw attention to literary form, showing in turn the extent to which literary forms shaped representations about these political debates. This study is inspired by several critical approaches. It is anchored in the New Historicism in that literary critics who have studied medical fiction have not paid significant enough attention to the context of medical professionalization to make it a focal point of study. This project is also grounded in Cultural Materialism as it illuminates the function of literary texts in shaping political ideologies about class. Each chapter surveys popular literary forms that thrived in different time periods where the 
medical profession either struggled or thrived. The goal then is to illustrate how varying writers employed each mode to perpetuate political ideologies concerning the profession; this work also showcases how some writers, whose politics were marginalized by the way other writers employed the form, innovated within these structures to create texts with ideologies different from the norms. To conduct this work, we thus prioritize historicizing these texts while also not forgetting the importance of form in disseminating these ideologies.

This project follows from a long history of criticism: The New Historicism emphasized contextualizing due to the limitations of the New Criticism; in the 1980s and 1990s, and over the past few decades, critics have argued that the method no longer appreciated the artfulness of the text. In her book Bodily and Narrative Forms: The Influence of Medicine on American Literature, Cynthia Davis argues that "new historicists often textualize context with too little regard for the literariness of the literary artifact and with too much regard for how narrative content (and content alone) reflects social context" (5). This division has left the New Historicism feeling stale in comparison with other new forms of literary theory.

In this way, this project follows from a new attitude coined as the New Formalism. This approach found its origin with Renaissance studies, the same field where the New Historicism originated. In his introduction to the collected volume of essays Renaissance Literature and its Formalist Engagements, Mark David Rasmussen helped to start this discussion by contending that form is implicated in culture, and while new historicists like Stephen Greenblatt had done valuable work in explaining what is happening through contextual analysis, they also neglected the implications of form along with the method of explication. Rasmussen thus hoped that the volume would merely restart a "revived and critically self-conscious formalist practice" (9). As time has progressed, these critics have attempted to theorize a New Formalism by uniting both 
old formalisms and Marxist theory. Terry Eagleton's 1975 essay “Ideology and Literary Form”, for example, read T.S. Eliot's work as recasting "historical contradictions into ideologically resolvable form" (114). In reading Eliot, Eagleton contended that his formal devices "lay bare the imprint of the ideological struggles which besat the texts" (124). In her essay "Reading for Form," Susan Wolfson also traces the attitude of the proposed New Formalism back to an aphorism by Roland Barthes regarding the (old) historicism: "a little formalism turns one away from History, but... a lot brings one back to it...the more a system is specifically defined in its forms, the more amenable it is to historical criticism" (7). With all of this said, some consensus exists that a textbook definition of New Formalism has not been attained and that it has not reinvented the wheel with regards to retheorizing form (Levinson 561). It is more or less a general attitude that scholarly attention can be focused on both contextualization and form rather than an "ism" with a concise definition.

While paying due diligence to both contextualization and form, this dissertation examines how popular literary modes in America engaged with the class politics of professionalization. By paying attention to how each mode engaged with the class politics of professionalization, this project concurs with many previous critics that modes are inherently ideological. In his book The Political Unconscious, Fredric Jameson described forms as having ideological contents based on the general mode of production from which they emerged; thus, to find meaning in a text, one should trace a genre's history and note "the variations of their individual textual manifestations as it is to identify their original meanings" (Cohen 22). Taking Jameson's point in mind about how modes reflect how and why they were produced, Stephen Cohen argues that no matter what the author's intent, the very choice of picking a genre is an ideological choice among various contenders; therefore, the mode gives an audience an ideological context from which to interpret 
the text. Thus, "if the task of a historical criticism is to reconstruct the conditions of a text's production, an understanding of the social functions of the forms available to its producers and consumers is essential" (Cohen 32). This dissertation thus adopts the theoretical framework from critics like Jameson and Cohen by illustrating to what extent authors engaged with the forms, amongst a competing number of them, to engage with the political discourse of professionalization.

Beyond the theoretical framework for this dissertation is also its engagement with fellow Americanists who have studied nineteenth-century medical fiction. These scholars have also called for a return to form; however, their projects differ from this one in the sense that the history of the profession along with focus on literary modes are the subject of discussion here, whereas the others focus more on specifics: notably, these studies have shown how the debates about professionalization affected writers' representations of the body. This dissertation goes beyond the discourses on $19^{\text {th }}$-century American literature and medicine from two projects: Cynthia Davis's Bodily and Narrative Forms: The Influence of Medicine on American Literature as well as Stephanie Browner's Profound Science and Elegant Literature: Imagining Doctors in Nineteenth-Century America. In the intro to her book, Davis notes that she examined bodily constructions through how said constructs were encoded within literary forms. Her project was then to discuss how constructs of the body were created not just from a thematic viewpoint but also a structural one. Davis calls representations of the body "denatured signs" that can be decoded through ideological examinations of form. While Davis's work focuses mostly on representations of the body through the loose term of "form," the method behind her project follows here in this project's emphasis on form, though this time from a lens more centered on the politics of professionalization during the times these forms were prominent. 
Furthermore, this dissertation also follows from Stephanie Browner's study, where she also spends significant time discussing literary form and the body. Compared to Davis, whose discussion was mostly predicated on form, Browner finds other ways to engage with the historical topic of professionalization: namely, she spends time discussing the physician-patient relationship as well as what was at stake regarding the patients' and doctors' bodies. Her book's concern is with writers who did not deny the advancement of medicine across the century but rather with the political implications of the profession's ascent into elite privilege and authority (3). She notes that fiction offers a unique record of anxieties raised and assuaged by professionalization, so it can offer a unique cultural history in examining this economic phenomenon. Browner's book thus pays close attention to both how form represented bodies as well as doctors themselves; the latter representation is more closely aligned with this project in that the physician characters are often the focal point of study regarding the political debates on professionalization. The main point of contrast between these studies is that greater attention is spent on literary modes and political subtexts here rather than contextualizing representations of the human body.

This dissertation shares both Davis and Browner's attention to form; however, this project is different from theirs in the sense of being more overtly concerned with political contexts rather than representations of the body. Each chapter surveys some of the most popular and prominent modes across a century long trajectory while asking how the limitations or lack thereof of the form affect a text's management of the competing marketplace of ideas. Because each form has an ideological underpinning that dictates the function of the individual text, it is integral to both identify the form, contextualize its politics to isolate why the author chose that form amongst a wide variety of them, as well as note the limitations of the form with regards to 
where a text goes thematically. Each chapter attempts to exhaust most of the relevant literature relating to medicine in each mode, though each one also focuses on specific writers who took a great interest in the issue for sometimes personal reasons.

Much of the discussion on form centers around the philosophical problem of determinism versus free will. Within each mode, many characters find themselves at the mercy of a type of formal determinism in which the author is trapped; nonetheless, the authors make purposeful choices for which form to adopt. Each mode exposes different webs of determinism: characters must engage with the formal determinism; others must deal with a cultural determinism contingent on the mood of the nation; and others face economic determinism based on the changing trends from the Jacksonian era to the Depression. Depending on which type of determinism authors engage with, they either reinforce the forms or purposefully subvert an existing form to advocate for a specific ideological focus. This determinism governs what sorts of attitudes and resolutions a text can take with regards to the politics of class interests. Depending on the mode, the function of a text might either strongly advocate for professional allopathy or indicate that laws should be relaxed to allow for alternative practitioners considering the limitations of allopathy and the allopath's perceived lack of concern for the patient. A text might suggest that both modes have problems and limitations, or a text might concern itself with who can enter the profession and who cannot, or what practicing physicians should be removed or not based on credentials. Another function might just be to represent the issue to allow readers to make up their minds. Across the dissertation, we shall see a number of these functions in different texts, but most at stake is the extent to which these forms navigate these varying levels of determinism. 
To ascertain the importance of form, each chapter spends considerable time historicizing the medical debates surrounding medicine at any given moment in the century. This separates this work from the other scholarship that, while giving some attention to the issue of the history of professionalization, mostly focuses on gender studies' criticism of representations of the body. At any given year across the nineteenth-century, public attitudes could drastically shift which in turn affected how existing popular forms synthesized and represented the debates. Considering these modes gained and lost popularity across the century, they found a homology in the changing status of the profession. While medical professionals united into a profession, American writers found a profession as writers for the first time; while antebellum writers like Hawthorne or Melville worked other jobs to support themselves, notable writers like William Dean Howells or Frank Norris found a profession in writing. To some degree, this similarity might explain why writers were so fascinated by what was happening in other professions, medicine being one of them. Writers dealt with the ever-changing power dynamic of allopathy. and as they processed the debates into representations, they found an underpinning in forms that were also products of their time. Some literary modes found themselves complicit with the eversolidifying establishment, others endorsed a greater freedom of choice in the American marketplace even as allopathy regained its prestige, whereas others remained ambivalent in exposing the limitations of both allopathy and the alternatives, which in turn calls for some reflection on what the profession could be rather than what is. Therefore, even in a discussion of form, context is key.

Chapter one centers around the gothic mode that was at its peak popularity before the Civil War. While multiple other authors could likely also be the object of study, this chapter focuses on the mode's most canonical authors, Nathaniel Hawthorne and Edgar Allan Poe, as 
both authors exhibited an interest in having medical practitioners as characters. These writers found themselves in the free medical marketplace of Jacksonian America where the professions were deregulated by law. Both Hawthorne and Poe had complicated relationships with both the mainline establishment and alternative practitioners. After spending ample time contextualizing Jacksonian democracy and the mass deregulation of medicine, this chapter argues that both Hawthorne and Poe employ the gothic mode with no political function in mind; instead, the gothic form allows for a kind of political ambivalence that allows both writers to tap into the unique fears Americans had for both mainline and alternative practices in an unregulated medical marketplace. Hawthorne's usage of an omniscient narrator comments almost didactically on his medical scientist characters: ranging from stories like "The Haunted Quack" to The Scarlet Letter, to espouse a pervading sense of skepticism about any sort of medical practice; mainline practitioners were represented as not having scientific advancement over the best interest of the patient in mind, whereas alternatives like homeopathy and mesmerism were represented as con artists and confidence men. Hawthorne also adopts nineteenth-century medical debates into his characters in seventeenth-century Puritan fiction as a means of indirectly commenting on his contemporary medical marketplace.

On the other hand, Poe's first person narrators put the reader into the mind of unreliable medical narrators whose descent into madness is based partly on scientific monomania; the chapter surveys stories such as "Berenice" and "The Facts in the Case of M. Valdemar" to demonstrate the extent to which Poe instigated the fears Americans demonstrated about philosopher-physicians who cared more about scientific innovation than patients. In this way, Poe could more astutely put the reader into the head of a character type like those of Hawthorne, which further exacerbates the divide between patient and doctor. Through both their innovations 
of the gothic mode, both writers found effective ways to appeal to Americans' fears about the medical profession and alternative practices; the gothic mode, above all others, showcased the divide between patient and doctor. The gothic form thus allowed both writers considerable freedom to lampoon the entire medical marketplace without having to endorse any dominant ideology about professionalization; it was a perfect way of representing American anxieties about medicine in a unique period of history where almost unlimited options existed on the medical marketplace.

Chapter two examines the mode of American Realism, which grew in prestige in the decades after the Civil War. The chapter surveys the long history of realism scholarship, but it extends from Amy Kaplan's assertion that realism is a notoriously conservative form whose function reinforces existing power dynamics. While the aesthetic is based on "the real" and events happening within the realm of possibility alongside its focus on aesthetic symmetry and unity, it tended to be a restrictive form that did not allow characters the free will to break free from narrative determinism. In large part, this was due to the political function of the work of William Dean Howells, whose work endorsed the status quo of protecting the profession from outsiders On the debates concerning medical professionalization, especially with women being allowed entry into it, the mainline literary establishment realists wrote fiction regarding this subject alongside a group of women counter-realists whose self-aware work allowed women greater agency to become successful practitioners. Each of the authors surveyed feature a woman doctor who must choose either to enter the profession or marry.

The chapter begins with Howells and his book Dr. Breen's Practice, whose protagonist, Grace, decides to leave the profession and marry, due in large part to the fact that the novel's neat unity would be disrupted otherwise. Other writers writing medical fiction then had to adapt 
Howells's structure into their own works, and the ways in which they represented their doctors showcased competing ideologies about professionalization in the realist mode. Elizabeth Stuart Phelps's novel Dr. Zay features a doctor who does choose to marry her suitor, Yorke, but the book's symmetry is disrupted so much by what seems like a forced marriage that the reader is left feeling uncertain about Dr. Zay's future happiness. Sarah Jewett's A Country Doctor is a bildungsroman featuring Nan, a character whose 'calling' is medicine. When tempted by marriage, Nan chooses to instead practice, which is a resolution made whole by narrative symmetry. The chapter ends with Annie Meyer's Helen Brent, M.D, whose character, Helen, is not trapped by narrative determinism and has plenty of freedom to choose her own actions. As a result, the book becomes didactic in nature as the book clearly preaches the message that it is okay for women to seek occupations outside the domestic sphere. Realism is thus bound with some sort of determinism, and the medical professionalization debate allows the reader a way to work through this complicated web.

American Literary Naturalism is the subject of chapter three. While realism as proposed by Howells tended to have a conservative function that reinforced existing power dynamics, naturalism proved to be a politically charged mode hostile to the notion of professionalization. As a form, naturalism embodies theme even more than structure; as a whole, the form appeared to value how the individual agent was affected by social forces, one being professionalization. Like realism, naturalism is interested in the notion of free will and determinism, with naturalism showing that determinism is an indifferent force to humanity. The works surveyed here accentuate the economic determinism limiting Americans through professionalization. The notion of professionalization centers on common like-minded individuals protecting their interests by protecting the skills and qualifications of their group from outsiders. Because of this 
exclusion, professionalization creates a new web of economic determinism that prevents the poor from entering the middle class.

The chapter centers on four writers: S. Weir Mitchell, Charlotte Perkins Gilman, Frank Norris, and John Steinbeck. The chapter contrasts Mitchell and Gilman, the former of which proved to be Gilman's target in "The Yellow Wallpaper" for his rest therapy cure. As a leading man of allopathy, Mitchell's novel Autobiography of a Quack calls for the need for professional standards considering the amount of crimes his protagonist, Sanderaft, commits in a free medical marketplace. In part of her direct response with "The Yellow Wallpaper," Gilman thus discredits not only the therapy prescribed by Mitchell but also the ideologies of professionalization that Mitchell perpetuated in his own fiction. Without the overwhelming authority of the professions, the narrator in the "Yellow Wallpaper" would have more credibility; like the Jacksonian era, this case again proved that allopathy did not have the patient's best interests in mind. Frank Norris's McTeague centers on a successful dentist who lives a happy and comfortable life until his right to practice dentistry is taken away because he never received schooling in his profession. While one of many of the book's subplots, the theme of professionalization is key in discerning to what degree of sympathy to feel for McTeague. This chapter posits that Norris painted McTeague as a competent dentist despite some of his other shortcomings, and it is the impersonal nature of economic determinism that causes his downfall more so than his biological dispositions. In this way, Norris thus employs the melodramatic tendencies of naturalism to show how the profession destroyed a man. The chapter ends with a few selected texts from Steinbeck: "The Snake," The Pearl, and The Forgotten Village. "The Snake" showcases a scientist who questions the ethics of his profession with regards to his animal specimens. The story calls attention to questions of medical ethics with regards to the professions; while the story is about a scientist and animals, it 
illuminates the debates surrounding the lack of care the patient receives from the allopathic profession. Both The Pearl and The Forgotten Village center on the entrance of professionalized medicine into Mexico; both texts showcase the lack of regard for the patient by mainline healers compared to alternative and spiritual healing.

Chapter four investigates the extent to which the mode of literary satire was affected by the debates surrounding professionalization. The subject of satire and medical competence could be a broad and comprehensive one as almost every American humorist, especially with frontier humor, took up the subject in some way. Therefore, rather than making a claim about all American humor writing on medicine, this chapter chooses Sinclair Lewis's Arrowsmith as the focal point of study seeing how Lewis's text also fits into the end of this project's historical timeline. The chapter situates Lewis as a "satiric realist" as his satire, while grounded in the real, is self-aware of the flawed ideologies of the realist paradigm. Lewis also name drops several realist writers: Howells and Thackeray, in the novel, giving it a referent point to the realist form. The chapter contends that Lewis's novel is much like Twain's Huck Finn in the sense that all its themes cannot be resolved into a neat, symmetrical ending that resolves all conflicts. The novel centers on Martin Arrowsmith and his long career as a country doctor, a public health administrator, and a laboratory scientist. Lewis's project encompasses many of these different sects, but the novel especially lampoons the allopathic profession. Because Arrowsmith cannot find an appropriate venue to host his research either in higher education or corporate laboratories due to administrative agendas in both, he exits his profession by the novel's end, and he decides to move into the woods and start his own laboratory. The chapter goes into detail close reading all the issues Lewis satirizes, but its main point is to showcase how Lewis employed the satiric 
mode in response to realism. This novel's unsatisfactory ending is a direct response to the neat symmetry of realist novels, just as Twain's Huck Finn was.

The dissertation ends by surveying several television and film adaptations of the medical profession, showing in turn how all of them can be traced back to the nineteenth-century representations discussed throughout this project. In an age of increased skepticism about the medical profession, a wide variety of new medical shows emerge every year; medical dramas have become staples of most every major network. Discussed here are a number of popular shows like E.R, Doctor Quinn Medicine Woman, and Nip/Tuck; these examples are compared with the various texts covered throughout the chapters. These shows all exhibit similarities with the literary modes discussed throughout this project; this in turn showcases the extent to which addressing issues of literary form with Americans' complex relationship with the medical profession remains an important project to consider in future studies of both literature and popular culture. 
Chapter 1: The Philosopher Physician: Gothic Fiction and the Deregulation of Medical Professionalization in Jacksonian America

\section{Part 1: Introductory Thoughts:}

The late Antebellum Period in American history, dominated by the spirit of Jacksonian America, was not an ideal period for American medicine. Allopathic medicine, the medical establishment long dominated by the likes of Dr. Benjamin Rush, faced unprecedented challenges from homeopaths, folk healers, and other pseudoscientific practitioners. As L Kerr Dunn notes, the average patient in Antebellum America faced numerous possibilities as it was "just as likely to have a healer feel your skull, apply leeches to your flesh, put you into a trance, hand you a bag of herbs, administer a water cure, or urge you to cleanse your spirit to heal your body" (2). The fact that many alternatives existed within the confines of late Antebellum America was based on many factors as a whole, including, as historian Richard Hofsteader puts it, "the widespread belief in the superiority of inborn, intuitive, folkish wisdom over the cultivated, over-sophisticated, and self-interested knowledge of the literati and the well-to-do" (qtd. in Whooley 62) along with the fact that allopathic regulars lacked a clearly defined organizational apparatus to fend off competition from alternative practitioners. Lost in this jumble between sparring medical sects was the patient, the agent who had to negotiate between them in an unstable public space with few regulations put on medical practice by the states.

In practicing a literary mode to scare or at least alarm readers, both Nathaniel Hawthorne and Edgar Allan Poe's fiction illustrated the point that in the increasingly unstable market of Jacksonian America, little hope exists for patients to find the care they need; however, both authors in their fiction demonstrate hope for a more promising future for the patient. Within their 
works dealing with medicine, both Hawthorne and Poe attempted to negotiate with the unstable, liminal space that was the medical marketplace of Jacksonian America. Jacksonian America was a transitional period for allopathic physicians who sought to cure diseases that they thought were made manifest by moral and sexual degeneracy; those answers could no longer explain vast failings in heroic medicine with the rise of epidemics like cholera. Jacksonian America further emphasized the virtue of the rural white farmer and worker at the expense of political elites, and allopaths, often labeled as being elites, fought vigorously to protect their medical system oftentimes at the expense of the patient. Within their art, Hawthorne and Poe blurred the distinction between the traits of allopathic regulars and alternative practitioners into singular alarming mad scientist characters who never have the best interests of the patient in mind; instead, they seek transcendent means of knowledge, such as the search for the Fountain of Youth, or even a perfect Platonic ideal for their patient. Some physicians, such as Roger Chillingworth, even had a personal motivation for treating their patients. Both Hawthorne and Poe advocate for a patient-oriented approach going along with the spirit of alternative practitioners and the spirit of many Jacksonians' distrust of the medical establishment for not caring enough about the patient; however, both fail to necessarily endorse these alternative practices because as aforementioned, all traits are combined together into singular scientist characters embodying a number of alarming possibilities. When Hawthorne and Poe incorporate the gothic mode to take up the subject of medicine, the mode politically functioned in a way to suggest that Americans must resist medical infighting while embracing a system rigorous in its intellectual standards that emphasizes the needs of the patient.

The ethos of Andrew Jackson's America played a significant role as being a transitional period between the heroic medicine of the likes of Dr. Benjamin Rush and the later 
developments after the Civil War with the solidification of allopathy as a legitimate medical establishment with the creation of the American Medical Association. Historian Charles Sellars notes that in Jackson's America a "historic political coalition gathered to champion the equality and independence of white male farmers, workers, and small enterprisers” (312). Jackson's governing was predicated on the system of small government, and he appealed to populism in seeking the rule of the will of the people after his first defeat to John Quincy Adams at the hands of the House of Representatives. Jackson had a special disdain with the political elites of America following his loss to Adams, and one of his first steps as President was to purge the executive branch of anyone affiliated with Adams. One of the fundamental characteristics typical of the Jackson years, along with the years of his various Democratic successors, was the rally against capitalist abuse of government" (325). Jackson himself called for a "stand against all new grants of monopolies and exclusive privileges, against any prostitution of our Government to the advancement of the few at the expense of the many, and in favor of compromise and gradual reform in our code of laws and system of political economy" (326). Jackson employed this rhetoric both in his struggles against the National Bank of Nicholas Biddle and against the slaveholders of South Carolina as Jackson dealt with the Nullification Crisis, calling in the latter for the support of "the united voice of the yeomanry of the country" (329). This rhetoric also extended itself to the states, where many of them repealed medical licensing laws because as aforementioned, medical professionals were seen as elites protecting, to borrow from Jackson's phrasing, their exclusive privileges.

Allopathic physicians, following the likes of Dr. Rush, found themselves at odds with the American public as many states, embracing the populist message of Jackson, found themselves at odds with the physicians for what many believed to be a group of elites protecting their 
privileges. Allopathic physicians emphasized a rational examination of the patient. It has been noted by previous historians of medicine that these rationalist physicians emphasized logical deduction over empirical induction. In treating cholera, for instance, early allopaths focused on how already established philosophical speculation might solve the problems of the disease. Such questions might include, "Did cholera represent an excess of bile? Was it an imbalance in the humors? A new manifestation of fever?" (Whooley 43). The victors in these discussions were not the patients successfully treated for the disease but rather the physician who possessed the tightest analogical reasoning.

As the early allopathic establishment emphasized logical deduction, they found themselves at odds with the spirit of Jacksonian Democracy as it was common to want to democratize previously inaccessible cultural apparatuses to the whims of public opinion. Historian Owen Whooley notes that since allopaths grounded "their authority on their reputations, regular physicians felt little compulsion to justify or explain themselves to the lay public. Instead, they resorted to authoritative testimony in communicating knowledge" (46). In this way of explanation, "facts" were "not presented but proclaimed" (46). The status of the physician spoke for the physician's competence, and the physician's reliance on elite knowledge like Latin "demarcated knowers from non-knowers," as the "language of medicine signified membership in an elite community. If one could not participate in such Latinate discourse, one was not meant to meddle in medicine" (46).

In addition to the methods allopaths espoused, the medical education they received was significant in understanding the general distrust of allopathy as not prioritizing the needs of the patient. Medical education from the late eighteenth to the early nineteenth century featured an apprentice system as one physician learned from another, and any additional education on top of 
that was deemed supplemental. Most of the medical education in early medical schools involved existing physicians providing lectures, and these institutions had little to no ties to the larger university (Weiss \& Miller 350). As time progressed further toward the 1820s and 1830, allopaths faced competition from alternative practices and began taking open admissions policies toward these medical schools to the point that barely literate applicants could find admission (350). Furthermore, a general Jacksonian-era hostility to "elitism and occupational protectionism exacerbated competitive pressures" in leading to the decline of these medical schools.

Finding themselves at odds with the tendency for states to open the medical marketplace to alternative practitioners, the medical establishment took it upon themselves to protect their role by becoming moral philosophers to keep their legitimacy on the free medical market. Revolutionary physician Dr. Benjamin Rush had once proclaimed that it is "as much the business of a physician as it is now of a divine to reclaim mankind from vice," and he espoused a theory of disease as it being "a habit of wrong action," and "all habits of injurious tendency are diseases" (qtd. in Sellars 252). Allopathic professionals thus found themselves in the moral arena with regards to sexual behavior; insanity wards sprung up in response to what medical professionals deemed as "masturbatory insanity", and professionals also sought to control the female libido with the rise of gynecology. The most prominent situation arising in this regard was Alabama country doctor J. Marion Sims, known for experimenting on slave women and going as far as to invent a "uterine guillotine" to amputate the cervix. The allopathic practitioners also featured only white men; it took until the 1850 s for women to be admitted into medical schools, and a famous scandal broke out at Harvard in 1850 over whether to admit African Americans into the program, including author Martin Delany. The traditional heroic 
medicine thus sought to protect its legitimacy even as it faced challenges from many states who wanted to open the medical marketplace to other sorts of practitioners.

With the decline of allopaths in the Antebellum Era came an increase in alternative practitioners, many of whom became the subject of attention in various gothic stories. Samuel Thomson's book A New Guide to Health originated at the right time, as the book prescribed many do it at home remedies suggesting in turn to common Americans that they did not need a physician when they could do the necessary tasks themselves. One did not need knowledge from books in Thomson's system but rather the common sense of the people, as "folk wisdom was prized over education" (52). Homeopaths responded to allopaths' inabilities to handle outbreaks of cholera by attacking some of their common practices like bloodletting as making the disease worse, and the constant deaths from cholera were painted as "an exemplar of what happens when a profession with monopolistic power cannot be held to account. The cruelty of heroic medicine in treating cholera was a direct outcome of licensing laws that encouraged callous experimentation" (54). Thomson himself argued that "the practice of the regular physicians, that is those who get a diploma, at the present time, is not to use those means which would be most likely to cure disease; but to try experiments upon what they have read in books, and to see how much a patient can bear without producing death" $(1825,199-200)$. Thomson thus argued not only that allopaths' methods did not work but also amplified the point that allopaths more or less resemble philosophers with little concern for the patient. An allopath would experiment on a patient for the benefit of testing theories from books at the expense of the patient's well-being; he even went as far as characterizing them as torturers. By the time Hawthorne and Poe were writing their gothic stories, this popular fear that allopaths had their professional interests in mind more so than that of the patient thus became widespread. Homeopathy allied itself with a 
common sensibility to trust individual knowledge and a society resistant to elites; however, this complete freedom and lack of medical stability also raises the question of what sort of doctors, if any of them, not only have the patient's best interests in mind but also possess the ability and knowledge to treat the patient.

Homeopathy, along with many of the other alternative practices, emphasized the needs of the patient beyond any strict methodologies. Unlike the regulars, who practiced deductive reasoning, homeopaths allied themselves with a sort of proto-empiricist movement that pushed observing and understanding the patient's needs. Bedside medicine stressed "the interrelationship between the patient and the doctor built on familiarity gained over time, in which the local doctor had extensive knowledge of his patients...doctors discussed the symptoms of the patient and applied their wisdom to determine treatment" (Whooley 44). Homeopaths combined empiricism with some new methodologies and breakthroughs that allopaths initially rejected, including statistical analysis in mapping the trajectory of where diseases like cholera might spread. They combined this with a belief in the vital force of the patient, a force encompassing “physical, mental, and spiritual properties, and disease represented disequilibrium in any of these properties" (55). What this vital force exactly was is unclear; therefore, homeopathy focused on the rigorous physical manifestations (i.e., symptoms) of how the vital force was responding to disease." Any treatment in a homeopathic system led toward the goal of restoring the body toward equilibrium considering this imbalance. Thus, while homeopathy did not have a strict methodology, their general philosophy valued the well-being of the patient in an era in which the individual was touted as the centerpiece of democracy.

It must be mentioned that allopathy endured challenges from a number of other medical theories and sects besides homeopathy in the unstable medical market that was Jacksonian 
America. While homeopathy was the main challenger, a plethora of other ideas also emerged. The aforementioned quote by Hawthorne scholar L. Kerr Dunn showcases the fact that a number of other possibilities emerged in the open marketplace, including mesmerism, physiognomy, and phrenology to name but a few (2-3). Hawthorne and Poe both adopt characteristic traits of many of these possibilities, and the potential dangers of mesmerism come into focus in several stories as the physician harnesses a great influence over the spiritual well-being of the patient. While fragments of these other medical sects survived after the Civil War, they were at the height of their popularity during this time as the medical market remained unstable due to the lack of a clearly defined standard of care.

The unstable medical market friendly to all sorts of alternative practitioners was a historical event common only to Jacksonian America, as the market was in flux from the early 1830s up until the Civil War. As a result, this was a unique social condition that informed the gothic works of Hawthorne and Poe. Allopaths did not succumb to the challenges presented to them by alternative physicians, as they attempted to respond in kind to challenges from democratic medical alternatives. By 1847 , they attempted an organizational strategy by forming the American Medical Association (Whooley 80). Historian Owen Whooley argues that organizations like the AMA are and were an "important resource in epistemic contests as they legitimate particular epistemological positions by configuring and institutionalizing communities of knowers and marshaling resources to promote the production of knowledge along certain epistemological lines" (83). The AMA refused to bend to the public because that could constitute quackery, creating standards in turn to draw a "strongly marked line of distinction between the educated and the uneducated, the liberal and the restrictive" (95). The allopathic standard became so strong that an allopath could be disbarred from the AMA for even consulting 
with alternative practitioners as they were labeled as quacks (100). By the time the Civil War arrived, even though the Union Army had an extreme shortage of physicians, they still did not allow homeopaths or others because the AMA began to gain legitimacy in the eyes of the American public. Because no cultural apparatus like the AMA existed during most of the Antebellum Era, the gothic fiction of Hawthorne and Poe was further intensified in that both writers created scientists with knowledge of many medical systems; therefore, no one could identify what beliefs or methodologies these characters had. With so many possibilities for representing physician characters, both Hawthorne and Poe thus found ample material for their characterizations ranging from the herbalist Rappaccini to the narrator of "Ligeia."

Both Hawthorne and Poe, in the process of fictionalizing the lack of priority paid to the patient, sharply critique the allopathic school in creating alarming physicians with allopathic characteristics. At the same time, both writers fail to indict allopathy by not endorsing alternative practitioners either. Instead, both writers synthesize important qualities from each school by displaying in gothic horror negative elements from both standard and alternative practitioners into singular scientist figures. This quality of both critiquing a power structure but at the same time reinforcing it has been a key dynamic in previous New Historicist studies on the gothic. Fred Botting, writing of early gothic examples in Eighteenth century British literature, notes that "the terrors and horrors of transgression in Gothic writing become a powerful means to reassert the values of society, virtue and propriety: transgression, by crossing the social and aesthetic limits, serves to reinforce or underline their value and necessity, restoring or defining limits" (7). Thus, as Gothic heroes or heroines escape from whatever may have befallen them, they then "manage to return with an elevated sense of identity to the solid realities of justice, morality, and social order" (7). In a similar vein, Stephen Bernstein in "Form and Ideology in 
the Gothic Novel" quotes Fredric Jameson when he notes that "form is imminently and intrinsically an ideology in its own right" and for the gothic mode in particular, Bernstein notes that "departure from social stability occurs through the manifestation of past crimes in the present, frequently in the form of more crimes"; therefore, the novels "become forums for the solution of these crimes and the restoration of property that the crimes' resolutions usually entail. Marriage is integral to this series, condemned if it violates the separation of the classes, approved if it consolidates property and endorses romantic love" (161). These readings suggest that the gothic mode possesses inherently conservative tendencies in reinforcing the traditional social order in terms of how it resolves its plot threads. Bernstein's reading is especially pertinent in regards to the earliest forms of the gothic mode in late eighteenth century British literature in works like The Castle of Otranto. Despite this longstanding history of criticism, the gothic has received attention from many other theorists including Marxist and Feminist critics who have made arguments regarding the Gothic texts showcasing fears about "revolutionary energies," a monstrous proletariat," along with their use in recovering texts addressing "issues of female experience, sexual oppression, and difference" (Botting 19).

New Historicist scholarship on the American gothic has pointed to the mode reinforcing power relations even as it critiques these power relations at the same time. ${ }^{1}$ The gothic has received significant treatment from New Historicist scholars including Teresa Goddu's Gothic America, which borrows from Stephen Greenblatt's Early Modern scholarship to show the gothic as being "part of a network of historical representation[s]' where the gothic is as "informed by its historical context", in a complex give-and-take, as "the horrors of history are also articulated through gothic discourse" (12). Jerrold Hogle articulates this as the Gothic playing "the role of the 'abject' by providing 'sites of historical haunting' in 'othered spaces or beings which 'harbor 
the cultural contradictions that undermine the nation's claim to purity and equality' and so halfquestion, half-uphold its power structures in the process of fictionalizing them."

This discussion of the role of New Historicist work in gothic criticism plays a role in this project, as the gothic in Jacksonian America does half-question and half-uphold the traditional power dynamics of the existing medical establishment. Existing in an age distrustful of professional authority, the gothic as demonstrated by Hawthorne and Poe showcases the lack of concern for the patient from all practitioners by combining qualities from both professionals and alternative practitioners into singular alarming physicians. Therefore, the gothic speaks to the populist concerns against medicine by fictionalizing allopathy as a branch of medicine more concerned with philosophy than practice; however, it does not endorse homeopathy or any other alternatives either by combining these qualities with those of medical regulars. It is significant to mention that stylistically, Hawthorne's works feature an omniscient third person narrator who gives details on the problematic physicians, and the lack of details provided blurs the distinctions between the type of physician to show that it is not the type of physician at stake as much as the lack of a standard for the patient's best interests. Poe, on the other hand, directly probes the problems inherent for the patient in medical debates by providing his stories through his firstperson narrators, all of which show a disregard for the patient at the expense of scientific gains or monomaniacal obsession. Not only do Hawthorne and Poe thus half-question and even halfuphold medical values in the act of fictionalizing them but also their distinctive styles allow us to discern the patient's perspective from differing lenses, further showing the flexibility of the gothic mode under the social conditions of Jacksonian America.

\section{II: Nathaniel Hawthorne's Philosopher Physicians}


Of all the writers practicing the gothic mode, perhaps Nathaniel Hawthorne was most intrigued by the medical profession. From early in his career to the works he did not complete before his death, Hawthorne had a long, complicated relationship with the medicine in his age for several reasons, and thus his fictional accounts involving medicine are likewise just as complex. Hawthorne's father in law, Dr. Nathaniel Peabody, was a homeopath, and his brother-in-law set up shop as a homeopathic druggist after his father; as a homeopath, he provided his own remedies to his patients (Stoehr 108). His wife, Sophia, likewise had many medical problems that Hawthorne would be sensitive to. At an early age, an allopathic physician gave Sophia a dose of paregoric as she was teething, and her father feared that this sedative contributed to the general debility of her adolescence along with the chronic headaches she developed throughout the rest of her life (108). Because of this early treatment by allopathic physicians, Sophia grew partial to homeopathic physicians both in her care along with the treatment of her children. In his later years, Hawthorne himself developed an antipathy for any type of medical treatment while his own health failed him. In an attempt to get a change of scenery for his declining condition, Hawthorne traveled to Cuba with his friend George Ticknor, who died there of pneumonia. In Ticknor's last treatments, the allopathic physician, according to Hawthorne, "belabored with pills and powders of various kinds, and then proceeded to cup, and poultice, and blister, according to the ancient rule of that tribe of savages" (124). A week before Hawthorne's death, he visited his old friend Oliver Wendell Holmes, perhaps an exemplar figure of allopathy, who told him "the shark's tooth is upon him" (124). Nonetheless, perhaps Taylor Stoehr says it best when he states that "it is no wonder that Hawthorne feared to consult a physician himself" following the death of Ticknor, as "the homeopaths were quacks, the allopaths witch doctors" (124). 
Hawthorne borrows an important quality from homeopathy throughout the course of his medical fiction, a belief in treating the vital force of the patient and keeping the patient at an equilibrium. As aforementioned, the vital force encompasses not only physical but also spiritual ailments; any illness was an imbalance in the equilibrium of the person's vitality. Hawthorne's doctors do not properly treat the vital force in their quest for knowledge; rather, they often poison it in their quest for knowledge or perfection. Hawthorne's gothic doctors likely unsettled the readers of his day, who were aware of the tenets of homeopathy, because they find doctors who have no interest in taking a patient-oriented approach. This moral obligation toward treating the patient also fits into discussions of Hawthorne's larger moral project. As Hawthorne scholar Michael Colacurcio has illustrated in The Province of Piety, much of Hawthorne's larger project has centered on Hawthorne's role as moral historian in relating to his Puritan ancestors (35). Hawthorne's interest in the patient, who is treated at the mercy of the doctor, is indeed a moral one as well, and his interests in locating many of his physicians in the distant past further amplifies his project of using the past to comment on the present.

Published in 1831, Hawthorne's early story “The Haunted Quack” features a homeopath riddled with guilt over his duping of a patient, leading to her supposed death. Concerning this rarely anthologized story, L. Kerr Dunn notes that "although lighter in tone and more sympathetic to doctors than later stories, this tale anticipates Hawthorne's more virulent attacks on unethical medical and scientific experimentation" (23). This story incorporates many of the themes of the gothic novel from Bernstein and Botting, notably the guilt felt by a character for old sins. The narrator, a man taking a vacation to Niagara and finding transport on a canal boat to Utica, awakens from a nap and finds a man muttering to himself in his sleep; the narrator had already caught this man auspiciously turning away as if "conscience smitten by the remembrance 
of some crime, he dreaded to meet the gaze of a fellow mortal" (50). Supposing this man to be having a nightmare, the narrator attempts to wake him, only having the man cry out: "Why do you continue to torment me? If I did poison you, I didn't mean to do it, and they can't make that out more than manslaughter!” (50). Upon waking him, the tormented man, ironically named Hippocrates Jenkins, confesses to being a murderer and wishes to tell his tale. In this manner, Hawthorne begins the story in conventional gothic ways as some transgression has occurred, and the transgressor confesses his sins both to the narrator and the audience. This narrative style evokes many other earlier works as a means of evoking a gothic plot such as Frankenstein's narrative about creating his creature, which allows the reader to get an inside glimpse into the mind of a criminal. This type of literary expression, as David Reynolds has argued, was a titillating look into the lives of transgressors and proved influential to the gothic mode.

What starts out as a conventionally gothic story turns into a satire against the entire medical establishment, including allopaths and alternative practitioners. Hawthorne performs this task in such a way as to illustrate the lack of professional credibility that medical practitioners had; Hippocrates remarks that he was trained by a Doctor Ephraim Ramshorne and goes into depth about his training: "it was never exactly ascertained from what college the Doctor had received his diploma; nor was he very forward to exhibit his credentials"; however, when hard pressed into proving them, he brought out "some cramp manuscript of a dozen pages, in an unknown tongue, said by the Doctor to be his Greek thesis. These documents were enough to satisfy the doubts of the most sceptical" (52-53). Doctor Ramshorne must put up with the local lawyer, who claims that "the Doctor's Greek thesis was nothing but a bundle of prescriptions for the bots, wind-galls, spavins, and other veterinary complaints, written in high Dutch by a Hessian horse doctor; that the diploma was all a sham, and that Ephraim was no more 
a doctor than his jack-ass" (53). These passages illustrate in a tongue-in-cheek manner how this physician gained his authority. Hawthorne plays on the anti-intellectual currents of Jacksonian America to illustrate the fears many Americans had regarding allopathy being against the interests of the common American. The fact that Hawthorne picks Greek over Latin as the language of choice of Doctor Ramshorne further amplifies this distrust of elite knowledge, as even fewer people would have studied Greek than Latin in this period. The signifier of elite knowledge suggests that Doctor Ramshorne is an allopath, and thus the recollection of his own education by Hippocrates illustrates the fears of quackery from even the elite establishment. Hawthorne even goes as far as to capitalize doctor in these passages, further exacerbating the fact that this doctor possesses the cultural authority and has constructed his authority without being able to prove anything regarding his education.

The narrative's satire of allopathic medicine continues when Hippocrates mentions the first time that he tried to learn anything from a book he finds at the doctor's office. On dusting off the old tome and trying to "puzzle off the hard words with which it abounded", Hippocrates has the book ripped from him, "like the evil one by Cornelius Agrippa's book" and the doctor told him to "not meddle with what I could not understand" (54). Shortly thereafter, Hippocrates must put together all the doctor's remedies, one of which included a mixture "of a little brick dust, rosin, and treacle, dignified with the title of the anthelminthic amalgam" that sold for half a dollar, along with "a bottle of vinegar and alum, with a little rose water to give it a flavor, yclept the antiscrofulous absergent lotion, brought twice that sum" (55). When the doctor gets sick, he orders his remedies, and despite Hippocrates pouring down all the drugs in the shop "with an unsparing hand", he dies" (54-55). These details suggest that both Hippocrates and Doctor Ramshawe are nineteenth century confidence men, seeking to dupe the population with false 
remedies. Hawthorne again points to the confidence they inspire in the populace with their presumed academic education. Whether or not Hawthorne intended an allusion to Frankenstein here, it is difficult not to place an allusion to the works of Cornelius Agrippa from that novel, which Victor Frankenstein had read and was chided on because of Agrippa's faulty philosophy that did not match the standards of contemporary science. The state of the dusty old tome suggests that Doctor Ramshawe too does not understand the scientific rigors of his profession; otherwise, he would have ordered a different remedy for himself while he was ill. While humorous, Hawthorne returns to the gothic mode along with the tales of criminal exploits that inspired it to amplify the level of guilt Hippocrates feels about his situation from the beginning.

Hippocrates' confidence scheme implodes on him when he finds a difficult patient in Granny Gordon. Hippocrates invents a mixture called "The Antidote to Death, or the Eternal Elixir of Longevity" that becomes a hit with the repulsive Granny Gordon; Gordon is both the object of humor and gothic character in her own part, as she has a hideous cloak that makes Hippocrates shudder, and she "would make her way into the patient's chamber, and disturb his repose with long dismal stories and ill-boding predictions; and if turned from the house, which was not unfrequently the case, she would depart..." (57). Hippocrates bestows his remedy to Granny Gordon, and when she does not get any better on her deathbed, she proclaims: "This is your doing, you villainous quack you...you have poisoned me, you have...but I'll be revenged" (58). Upon returning to the town, Hippocrates finds that it's a misunderstanding, as Granny Gordon's husband tells him that "my old woman soon got well of her fit, after you went away and says she thinks the stuff did her a mortal sight o' good" (60). The story ends with the narrator warning Hippocrates to be more careful in the future, as "all old women had not nine lives" (60). 
This story concludes with Hippocrates learning nothing of his actions, continuing his practice until the next possible incident arises. "The Haunted Quack" does not endorse the power structure of allopathic medicine; rather, the story closes with chaos in this small town as the townspeople again are inspired by the local confidence man. The story inverts the normal gothic resolutions that reinforce existing power structures by showing that there is no medical authority, in turn revealing to the Jacksonian audience their already existing underlying fears on allopaths as being corrupt, elitist professionals who do not know as much as they proclaim. This resolution also leaves the audience with a lingering fear that they could encounter a physician of this caliber. While this story has a humorous edge to it, the combination of satire with gothic tropes create an unnerving effect about the lack of consistency in American medicine.

“Dr. Heidegger's Experiment," originally published in Knickerbocker's Magazine in 1837, again exhibits Hawthorne's early tendencies to process the gothic mode in conjunction with medicine as satire. Reading the story as satire is not a new idea itself, as many New Critics like Harry Levin pointed to the idea, but no consensus seems to exist in the scholarship as to what exactly it does satirize (Scanlon 253). The premise of the tale is simple: Dr. Heidegger discovers the secrets behind the Fountain of Youth, and he invites four elderly people: Mr. Medbourne, Colonel Killigrew, Mr. Gascoine, and the Widow Wycherly to his laboratory to test his tonic. As the tale progresses, the four elderly people find themselves getting younger with each new glass of the tonic they consume until they find themselves in the prime of their youths. In turn, the four start partying and showcase the base elements of human nature as the three men fight over the now young Widow Wycherly. As they fight among themselves, the Doctor's mirror showcases that this new youth is only a surface impression as their old age is still reflected in the mirror. The story concludes with the tonic spilling as the men brawl and all four 
characters returning to their old age. Broken, they all choose to spend the rest of their days searching for the Fountain of Youth. Hawthorne again satirizes the allopathic establishment for failing to help the patient; instead, the patients leave the tale with a nervous obsession to cure the youth they waste. The satire is didactic in nature, as it speaks to the anti-intellectual nature of Jacksonian America in that allopathic physicians were philosophers who did not always have the best interests of the patient in mind. Instead of treating the physical, or perhaps the moral ailments of his patients, Dr. Heidegger, in his vain quest for knowledge, overreaches and only treats the symptom of old age rather than the grand result of a lifetime of experiences and failures, or the vital force of the patients. This story contributes to Hawthorne's larger moral history project in illustrating how little attention doctors pay to the needs of patients, as Heidegger does more harm than good in not treating their vital forces; rather, he exacerbates their vices, repressed by old age, by restoring their youth to them, in turn leaving them with an emptiness that subsumes them when the tonic's effects fade.

Hawthorne characterizes Dr. Heidegger in the second paragraph of the story following a brief mention of his patients. This characterization engages with various gothic tropes in addition to providing numerous details clouding the representation of the sect to which Heidegger belongs. Hawthorne notes that Dr. Heidegger's study was a “dim, old-fashioned chamber, festooned with cobwebs, and besprinkled with antique dust" (471). In addition, Heidegger has a "bronze bust of Hippocrates" over the central bookcase, and in what looks to be a nod to the classic theme of gothic guilt, the doctor has a literal skeleton in his closet in addition to a mirror in which it was "fabled that the spirits of all the doctor's deceased patients dwelt within its verge, and would stare him in the face whenever he looked thitherward" (471). The narrator does not leave much to the imagination either, as he mentions that Heidegger had a full-length portrait of 
a young lady who was his fiancé almost half a century ago, but she passed away as she “swallowed one of her lover's prescriptions, and died on the bridal evening" (471). The last object of note is a large folio collection that was said to be a "book of magic, and once, when a chambermaid had lifted it to merely brush away the dust, the skeleton had rattled in its closet, the picture of the young lady had stepped one foot upon the floor, and several ghastly faces had peeped forth from the mirror; while the brazen head of Hippocrates frowner, and saidForebear!" (471-72).

This passage does not present a clear picture of the proper medical establishment Heidegger belongs to as it demonstrates that he has both allopathic and homeopathic tendencies. By creating this figure, Hawthorne creates a scientist/philosopher archetype illustrating the instability of early nineteenth century medicine as Heidegger treats the patients as test subjects and in turn does more harm than good. The narrator points to much of the hidden guilt Heidegger has as well as giving classic descriptions of old cobwebs and dusty tomes. The details concerning Hippocrates, the prescription, and the folio said to be magical is of the most concern here. As mentioned with previous stories, allopaths did not possess the rigorous scientific methodology that they would adopt later in the century as they embraced the laboratory. Allopaths were perceived by the general public as being greater philosophers than scientists. Heidegger's possession of a Hippocrates bust exhibits the tendency of many Antebellum Americans to classify allopaths as philosophers of medicine who at best could replicate the knowledge of antiquity rather than pursuing an empirical method based on the patient's needs. The magic book likewise exhibits this same tendency; Heidegger is painted from the onset as a Faustus type figure interested in metaphysical gains rather than his patients. One might also characterize Heidegger as a homeopath based upon the fact that he emphasizes alternative 
therapies (the tonic of Youth), in turn turning against the medical advice of allopathy. One of his prescriptions caused the death of his fiancée, but unlike other characterizations of homeopaths in Hawthorne, including “The Haunted Quack" and Chillingworth in The Scarlet Letter, it is significant that no discussion of how Heidegger invented this remedy is presented; Heidegger admits that he is sent the water from an acquaintance who knows his "curiosity in such matters" (473). With all of this in mind, the ambiguity of details regarding Heidegger suggests in turn the same ambiguity many would experience in Antebellum America as the distinctions between healers were often unclear to the patient seeking medical help. Heidegger is a blend between an allopathic philosopher and a homeopathic healer. The tale suggests in turn that such an instability proves detrimental to all patients as a collective whole because in the quest for newfound metaphysical knowledge, these patients are left broken and hapless.

Hawthorne's satire continues across the tale as the characters drink the elixir from the Fountain of Youth. At first, they watch Heidegger apply the elixir to a rose from his wedding day, and when asked to comment, they say that the rose's sudden change is "certainly a very pretty deception...for they had witnessed greater miracles at a conjurer's show" (473). This again constructs Heidegger as a Faustian figure whose ambitions lead him to being but a mere conjurer rather than a scientist. Yet, after receiving the elixir, the four people revel in merriment, and the men even compete for the newly reinvigorated Widow Wycherly as the narrator notes that they were "inflamed to madness by the coquetry of the girl-widow, who neither granted nor quite withheld her favors" and then they "grappled fiercely at one another's throats" (478). Even during the revelry, the narrator hints that Heidegger only cured the surface symptoms of old age, not the root cause, the result of all life experience, when he notes that "by a strange deception, owing to the duskiness of the chamber, and the antique dresses which they still wore, the tall 
mirror is said to have reflected the figures of the three old, gray, withered grand-sires, ridiculously contending for the skinny ugliness of a shrivelled grand-dam" (478). Hawthorne paints Heidegger's medical experiment as unsavory and lacking the wisdom and ethics necessary for good medical practice. Heidegger is more interested in grand philosophical ideas rather than his patients. The mirror image not only displays the futility of the patients not learning anything new in their old age but also the lack of practicability of Heidegger's medical practice.

The text concludes with Heidegger admitting the fault of his experiment, further amplifying the gothic conclusion that Heidegger's patients cannot escape from the illness that pervades them, human nature. It also exacerbates the satiric edge of the story in that it directly implicates Heidegger and the medical ideals he espouses as a failure, as the patients are now worse for his help than they were before his experiment. The tonic fades away and the patients grow old again, and what elixir Heidegger has is spilt during the revelry of the party. When seeing that the Widow Wycherly wishes herself dead after she sees her face old again, Heidegger proclaims: "if the fountain gushed at my very doorstep, I would not stoop to bathe my lips in itno, though its delirium were for years instead of moments. Such is the lesson ye have taught me!" (479). The story does not end with Heidegger's realization, however, but the narrator notes that "the doctor's four friends had taught no such lesson to themselves. They resolved forthwith to make a pilgrimage to Florida, and quaff at morning, noon, and night, from the Fountain of Youth" (479). Although this ending is tongue-in-cheek, this tale comes to a resolution that leaves the characters paralyzed by this newfound disease, a newfound psychological insecurity about their old age, and it's all because Heidegger was negligent to the patient in his pursuit of knowledge for knowledge's sake. While scholars have identified that the story has a satirical edge to it, it is significant that the story ends with Heidegger's realization about his experiment 
and the result, broken patients. In this tale, just as he does in "The Haunted Quack," Hawthorne thus comments on the instability of Jacksonian American medical culture and illustrates the need for an American medical system emphasizing both scientific rigor and patient ethics.

At the heart of his often-anthologized story "The Birthmark" is a narrative showcasing not only the popular fears about the instability of Jacksonian America's medical culture but also the fears about how little agency the patient had within this medical market. While other scholars have addressed the medical implications of this text, namely Georgiana's vulnerability as a patient to a sort of impersonal, Foucauldian medical gaze, none have directly provided a full-scale analysis of the commentary the story makes on the treatment of all patients by doctors with a personal motivation as a historical lens for examining the story. ${ }^{2}$ Unlike other accounts of this tale, this analysis posits that Hawthorne created Aylmer to illustrate not an impersonal, clinical gaze in a Foucauldian sense but rather Aylmer embodies the dangers of an overly invested medical figure with Hawthorne's usage of a personal, albeit still penetrating gaze. Furthermore, the story illustrates the dangers of America's unstable medical market with its characterization of Aylmer. Aylmer possesses characteristics of both allopathy and homeopathy in his treatment of Georgiana, and Taylor Stoehr has commented on Aylmer's usage of homeopathic techniques in trying to treat Georgiana; however, it is his allopathic traits, including his characterization as an Enlightenment philosopher, that the story most seems to criticize. With "The Birthmark," Hawthorne thus calls for a medical system emphasizing the needs of the patient in its basic epistemology over the sake of knowledge for knowledge's sake.

It is significant to the story's discussion of medical ethics that it begins by characterizing Aylmer as a man of the Enlightenment. This has significant ramifications to gripping the story's medical theme because as aforementioned, critics of allopathy in the early 1830s lamented that 
the system had more of a concern for philosophical knowledge more so than a concern for the patient, resulting in the widespread repeal of state medical school licensing laws. From the opening lines, Hawthorne paints Aylmer as an Enlightenment philosopher: "in the latter part of the last century, there lived a man of science — an eminent proficient in every branch of natural philosophy" (764). Enlightenment philosophers had a scope reaching toward a sort of transcendent knowledge, argues the narrator, and of this pursuit of knowledge by the philosophers, the narrator argues that "in those days, when the comparatively recent discovery of electricity, and other kindred mysteries of nature, seemed to open paths into the region of miracle, it was not unusual for the love of science to rival the love of woman, in its depth and absorbing energy." Of Aylmer himself, the narrator notes:

We know not whether Aylmer possessed this degree of faith in man's ultimate control over nature. He had devoted himself, however, too unreservedly to scientific studies, ever to be weaned from them by any second passion. His love for his young wife might prove the stronger of the two; but it could only be by intertwining itself with his love of science, and uniting the strength of the latter to its own.

From the onset, the narrator thus portrays Aylmer as an Enlightenment philosopher, a man who could be concerned more with the love of science than even his wife, much less any possible patients he might encounter. The narrator also paints the Enlightenment as a historical moment distinctively in the past with phrases like "in those days" and "in the latter part of the last century" to show that this way of thinking is obsolete in the present, the 1830 s. Considering that the medical establishment in the present moment, allopathy, was often ridiculed for being too 
philosophical in scope, the significance of opening the story with this Enlightenment backdrop is thus paramount to reading how the story processes the medical theme within the gothic mode.

The story also illuminates the possible dangers of the Antebellum medical establishment with Aylmer's usage of a medical gaze; this gaze, however, is a personal gaze with a definite interest in the patient and not an impersonal, objectifying gaze as other scholars have emphasized. This gaze creates an effect of horrifying the reader in showing the dangers implicit in the physician having a personal stake in the patient for the sake of scientific advancement rather than the patient's needs, especially in this case considering the patient is a spouse. Early in the tale, the narrator remarks of Aylmer's gaze on the birthmark: "Georgiana soon learned to shudder at his gaze. It needed but a glance, with the peculiar expression that his face often wore, to change the roses of her cheek into a deathlike paleness, amid which the Crimson Hand was brought strangely out, like a bas-relief of ruby on the whitest marble" (766). Late in the story, after giving Georgiana the treatment for the birthmark, the narrator adds that "Aylmer sat by her side, watching her aspect with the emotions proper to a man, the whole value of whose existence was involved in the process now to be tested" (778-79). The story also showcases the danger of this medical gaze on the patient when it is mentioned that whenever Georgiana "dared to look into the mirror, there she beheld herself, pale as a white rose, and with the crimson birth-mark stamped upon her cheek. Not even Aylmer now hated it so much as she" (766).

These descriptions of a personal gaze all illustrate popular fears of allopathic tendencies in that Aylmer does not share a concern for his patient in his fascination with reaching his idealistic philosophical goal. In his account of the rise of nineteenth century medical technologies, Foucault notes that "the observing gaze refrains from intervening: it is silent and gestureless...in the clinician's catalogue, the purity of the gaze is bound up with a certain silence 
that enables him to listen" (107). While one could discuss the effects of the clinical, gestureless gaze in some detail, Hawthorne's physician Aylmer features more of a personal gaze, as the narrator mentions by noting the value of all Aylmer's existence is to be tested by his work on the patient. As a philosopher, Aylmer is more interested in an ideal, almost perfect idea (Georgiana as an ideal concept of beauty) than in Georgiana's well-being especially considering she has no true medical problems. Aylmer's monomaniacal quest for personal perfection manifests itself as a corrupting rather than a healing force in Georgiana as Aylmer poisons her own sense of selfworth in his quest for philosophical perfection. This idea of the physician's corrupting influence on the patient thus becomes a common theme of Hawthorne's medical writings.

It is significant that Hawthorne's narrator continues to discuss Aylmer's philosophical inclinations as the story progresses to further illustrate how distant he is from his patient. This effect illustrates not only Aylmer's monomania but also exacerbates popular fears on allopathy. Aylmer uses a classical allusion when he tells Georgiana that the pleasure he will take in conquering nature has no precedence: "Even Pygmalion, when his sculptured woman assumed life, felt not greater ecstasy than mine will be" (768). Just a few lines later, Hawthorne includes a long passage on Aylmer's laboratory, further amplifying the gothic setting of the place in combining it with Aylmer's monomaniacal pursuits for knowledge. The narrator notes that in this laboratory, the "pale philosopher had investigated the secrets of the highest cloud-region, and of the profoundest mines; he had satisfied himself of the causes that kindled and kept alive the fires of the volcano; and had explained the mystery of foundations..." (769). In addition to his natural history studies, Aylmer has also studied human anatomy, but had put them aside because he recognized that "our great creative Mother, while she amuses us with apparently working in the broadest sunshine, is yet severely careful to keep her own secrets, and, in spite of 
her pretended openness, shows us nothing but results" (769). Now, Aylmer resumes "these halfforgotten investigations" because they "involved much physiological truth, and lay in the path of his proposed scheme for the treatment of Georgiana" (769). In addition to the passages concerning Aylmer's penetrating personal gaze, this passage creates a gothic effect by showing how horrifying and pointless the pursuit of the type of knowledge Aylmer seeks is; it is best to not dig into the horrifying secrets of our creative Mother. This also embodies the common conception about allopathic medicine; Aylmer pursues his knowledge this far not in pursuit of the patient but rather "physiological truths." Without this description of the laboratory, a place darkened by Aylmer's monomaniacal pursuits, in the center of the tale, the story would thus lose an important element in its indictment of allopathy.

The tale ends in a didactic manner in warning readers to appreciate what they have as Aylmer kills Georgiana with the poisonous remedy that he concocted to remove her birthmark. The narrator concludes by referencing how Aylmer's quest to find a perfect Platonic form in effect became his undoing: "The momentary circumstance was too strong for him; he failed to look beyond the shadowy scope of Time, and living once for all in Eternity, to find the perfect Future in the present" (780). Hawthorne capitalizes words like Eternity and Time to amplify the fact that Aylmer chases an impossible ideal in his quest to cure the one flaw from the otherwise perfect Georgiana. The text thus takes a hostile attitude towards the physicians who prioritize knowledge for knowledge's sake over living in the present. It's better for medicine to exist in "the shadowy scope of Time", to live in an imperfect, almost Platonic cave of ignorance, then for it to go outside the cave and exceed its grasp on what it means to be human.

Even though Hawthorne ends the tale by warning the reader to learn a lesson, we do not get any suggestion that Aylmer learned anything from killing Georgiana; we only see the 
narrator telling the reader the lesson to learn from Aylmer's transgression. The fact that a physician like Aylmer could still linger even after the negligence shown to his patient should have unnerved a nineteenth century reader. Combine this with the uncertainty of what sort of physician Aylmer is; despite his philosophical, allopathic inclinations, the remedy Aylmer provides Georgiana is distinctively homeopathic in using poison for a remedy. While this tale ends didactically, this combination of Aylmer's overly personal stake in the patient with the story's blurring of different medical figures in an uncertain medical market invokes a number of anxieties Antebellum Americans felt about their practitioners. Aylmer did not realize the happiness his wife would bring him at the expense of medical research, says the narrator, but lost in this ending is the needs of Georgiana, the patient, whose last words invoke pity for Aylmer: "You have aimed loftily! —you have done nobly! Do not repent, that, with so high and pure a feeling, you have rejected the best that earth could offer. Aylmer—dearest Aylmer-I am dying!" (780).

One year after completing "The Birthmark," Hawthorne published another high allegorical, gothic tale regarding medicine, this time featuring a homeopath as the leading character with "Rappaccini's Daughter." As aforementioned, Hawthorne's wife Sophia turned to homeopathy for guidance for her migraine headaches; she and others in her family blamed allopathic physicians for causing this problem due to the harmful effects from drugs prescribed to her early in her youth (Cerulli \& Berry 120). The story in question features two physician characters, Rappaccini and Baglioni. Rappaccini is a homeopath as homeopathy emphasizes not only a connection with the patient but also the healing nature of poisonous materials. Baglioni, on the other hand, is the head of the medical school that Giovanni, the protagonist and lover of Rappaccini's daughter, Beatrice, attends; this situates him within the allopathic tradition. 
Scholars Anthony Cerulli and Sarah Berry posited that because Baglioni's antidote kills Beatrice, Hawthorne "ends the story with profound equivocality, for the gripping denouement does not reveal which medical practice is ultimately more effective. Hawthorne instead directs the reader's attention to the harmfulness of the men's 'warfare' itself' (121). They continue their reading by discussing the role of various characters in this reading:

Baglioni's verbal posturing is calculated for precisely these ends, with the primary aim of maintaining his seat of authority by manipulating Giovanni into aligning with allopathic orthodoxy and rejecting the irregular counter-discourse of Rappaccini. As an impressionable young student, moreover, Giovanni stands in for the public amid the scientific jargon of professionals, which is so often unintelligible to the masses, and in particular, the next generation of medical scientists. (122)

Cerulli and Berry's reading provides a clever way of reading the characters through the lens of nineteenth-century epistemic medical conflicts between allopaths and homeopaths, and this reading of the text does not dispute their claims but rather builds on them for the purposes of seeing how Hawthorne imagines the patient's role amidst this epistemic infighting within his gothic framework. Like in "The Haunted Quack," Hawthorne amplifies the uncertainty over which medical sect is correct to melodramatic proportions, this time however to showcase the fact that neither sect has the best interests of the patient in mind. As with the "Haunted Quack," the story does not reinforce existing power structures but rather showcases the alarming fact that no power structure offers a feasible system designed for the patient's best interests.

It is significant that Hawthorne spends a fair amount of time characterizing both Baglioni and Rappaccini, and he provides some relevant details illustrating that neither doctor cares much 
about the patient. Rappaccini, despite not being an allopath, possesses the same overly personal gaze as Aylmer from "The Birthmark," as the narrator remarks when Rappaccini passes Giovanni on the street: "this person exchanged a cold and distant salutation with Baglioni, but fixed his eyes upon Giovanni with an intentness that seemed to bring out whatever was within him worthy of notice...there was a peculiar quietness in the look, as if taking merely a speculative, not a human, interest in the young man" (988). Baglioni also makes it clear to Giovanni that he is part of some twisted scheme from Rappaccini upon passing him in the street: this man of science is making a study of you. I know that look of his! It is the same that coldly illuminates his face, as he bends over a bird, a mouse, or a butterfly, which, in pursuance of some experiment, he has killed by the perfume of a flower;--a look as deep as Nature itself, but without Nature's warmth of love" (988).

Hawthorne again uses the physician gaze motif to exacerbate the gothic elements in a story involving medicine. This time, however, the physician with this gaze practices homeopathic medicine and is not part of the establishment. Baglioni describes Rappaccini as making a science experiment of Giovanni; Rappaccini is a man obsessed with his test subject at the expense of his patient. Homeopaths, as aforementioned, were often seen as being alternative practitioners practicing empirical science, and they were practitioners who were attractive to the patient for their hands-on approach.

The causes for characterizing a homeopath as an ambitious scientist are contingent on the historical moment Hawthorne composed the tale as far as patients are concerned. While allopathy emphasized the role of rational, deductive reasoning, the homeopathic method tilted more towards a type of proto-empiricism. Historian Owen Whooley notes that "people were 
dying; the public was losing confidence; and the long-held intellectual traditions of allopathy weren't helping" (42). The bedside medicine started with an emphasis on "the interrelationship between the patient and the doctor built on familiarity over time, in which the local doctor had extensive knowledge of his patients...proto-empiricism sought to make this practical technique of bedside observation the foundation of medical knowledge" (44). This historical detail is significant to discerning Rappaccini's role in the text as near the end of the tale Baglioni asserts that Rappaccini is "a vile empiric, however, in his practice, and therefore not to be tolerated by those who respect the good old rules of the medical profession!" (998). What we see from Baglioni is thus the backlash the medical establishment took against any alternative practitioners. Homeopaths sought a patient-oriented approach, and Hawthorne's readership would have been acutely aware of that distinction. Rappaccini, however, illustrates the fears of too much interest in the patient from the homeopathic perspective, and to amplify this effect, Hawthorne makes Rappaccini a disinterested homeopath interested more in the experiment than the patient.

With the gothic backdrop in mind of Rappaccini making a test subject of his own daughter, it is important that Hawthorne provides no philosophical detail for Rappaccini's reasoning other than a fascination with the subject. It's also important to note that the pharmaceutical remedy given by Baglioni kills Beatrice, so one can raise the question over whether Rappaccini's empirical concoctions did a large degree of harm to them or not. Baglioni even gets the final word over Rappaccini as the latter stands over his daughter's corpse upon taking the remedy for his poisons; the narrator notes that "in a tone of triumph mixed with horror, to the thunder-stricken man of science: 'Rappaccini! Rappaccini! And is this the upshot of your experiment?” (1005). Cerulli and Berry raise important questions concerning this ending: "who does Giovanni train with now: Baglioni or Rappaccini? Does Baglioni know the 
antidote is lethal, intending to reclaim Giovanni as his own protégé by killing Beatrice?” (12425). They also raise the important point that "Hawthorne consistently points out the deadliness of medical factions protecting their own reputations at the cost of human lives" (125). What Cerulli and Berry's analysis points toward is again Hawthorne's concern about all doctors' lack of concern for the patient. With his overly personal empirical interest that lacks human compassion for his patients, his daughter, and Giovanni, Rappaccini is neither any better or different than Baglioni, his allopathic counterpart, because the story exhibits that neither physician cares much for their patients at the expense of their professional findings and their reputations as leading scientists. In this story, Hawthorne again demonstrates the unstable American medical market riddled with competition since states had repealed licensing laws for practice. In a market riddled with competition, these doctors were mostly concerned about extending their professional ethos, even, in the case of the homeopath Rappaccini, at the expense of the patient. The story's alarming ending thus points to the fact that like Beatrice and Giovanni, all patients must face doctors who, even if they take a personal stake in them as Rappaccini does, see them more as means to an end than as people needing treatment.

As Hawthorne transitioned from writing short fiction to novels, he imagined another gothic medical figure embodying characteristics of both allopathy and alternative medicines when he created Roger Chillingworth in The Scarlet Letter. It is not without coincidence that Hawthorne's characterization of Chillingworth also invites questions about the patient's role in the unstable medical market of Antebellum America. What, ethically speaking, goes wrong in Chillingworth's treatment of Dimmesdale, as Chillingworth in fact keeps him alive throughout the novel? The answer to this question rests with the similar sort of ideas aforementioned with the discussion of Aylmer and Rappaccini. As a physician operating in the seventeenth century, 
the inability to process what sort of physician Chillingworth is would also be applicable to nineteenth century patients who faced an unstable medical market. This would be alarming in itself, but the overly personal stake Chillingworth has in his patient would also prove unnerving to readers in a medical market that could, in theory, give rise to similar sorts of physicians, especially homeopaths in their more hands-on, patient-centered approach to medical care. Just as he does with Aylmer and Rappaccini, Hawthorne represents this lack of concern for the patient as an overly personal and involved gaze, showing in turn that Chillingworth does not have his patient's best interests in mind. Just as with Rappaccini, this sort of overly personal involvement with the patient poisons Dimmesdale spiritually, as he cannot move on past his sin of adultery with Hester. As homeopathy, the most patient-oriented ontological approach, was centered on maintaining the "vital force" of the patient, Chillingworth's great moral flaw as a physician is to corrupt Dimmesdale and thus throw off the equilibrium of Dimmesdale's vital force. Chillingworth's flaws as a doctor thus relates to Hawthorne's larger concerns about moral history in the sense that Hawthorne illustrates what current physicians should not do.

Hawthorne again creates with Chillingworth an effective blending together of multiple strands of medical thought to show that the distinction between them did not matter as no physicians had the best interests of the patient in mind. While the scholarship on The Scarlet Letter has a longstanding history involving multiple strands, notably Hawthorne's interrogation of the Puritan mind, a strand has emerged since the late 1970s attempting to discern what exactly Hawthorne is up to with his characterization of Chillingworth as a physician. ${ }^{3}$ Medical scholar $\mathbf{J}$ Dolezal has pointed to the fact that Chillingworth resembles multiple groups of physicians; this analysis concurs. It must be mentioned as well that despite similarities to nineteenth century medical sects, Hawthorne may have painted Chillingworth more closely with his moral history 
project. Walter Woodward notes in Prospero's America that in seventeenth century medicine, alchemy and chemistry were interchangeable terms, and alchemy was the part of chemistry that 'permeated, to its core, the 'spiritual understanding of created matter.' Alchemical medicine in New England relied upon and strongly benefited from this explicit linkage with the spiritual" (162). This $17^{\text {th }}$ - Century understanding of alchemical medicine as benefitting the spiritual core of the patient does, however, resemble the $19^{\text {th }}$ - Century's understanding of homeopathic physicians affecting the patient's vital force. Chillingworth's alchemical prowess in the $19^{\text {th }}$ century imagination thus allows him to get away with his crimes against Dimmesdale both because of the unstable medical market of Jacksonian America along with the lack of regulations imposed by a governing apparatus such as the American Medical Association.

It is significant in that like the seventeenth century, homeopaths in the nineteenth century also related physical ailments with the spiritual, vital force. When Hester is first marked with the scarlet letter symbol, the jailer, Master Brackett, introduces Chillingworth to her: "he described him as a man of skill in all Christian modes of physical science, and likewise familiar with whatever the savage people could teach, in respect to medicinal herbs and roots that grew in the forest" (178). Historian Walter Woodward defines seventeenth century New England medicine as "medical providentialism - the unwavering conviction among the godly that God played an active role in both inflicting and healing diseases" (164). Unlike England, who in the seventeenth century had a medical licensing apparatus, New England thus had no licensure and in fact "no university graduates worked there before 1671. Only three medical doctors...practiced in New England during the entire seventeenth century" (163). Significant about this discussion is the fact that in this free market without rules or restrictions, Chillingworth has almost unlimited discretion to practice however he wants. 
Even though Chillingworth exists in a medical society not requiring any medical licensing laws, Hawthorne does not depict him as a quack. Instead, he characterizes Chillingworth as a competent, well trained physician skilled in multiple arts: "as his studies, at a previous period of his life, had made him extensively acquainted with the medical science of the day, it was as a physician that he presented himself, and as such was cordially received" (21920). Furthermore, the narrator remarks that few other scientists partook of any religious zeal, and thus the Bostonians respected Chillingworth because his "piety and godly deportment were stronger testimonials in his favor, than any that he could have produced in the shape of a diploma" (220). The narrator also compares Chillingworth to his contemporaries in the colony: "the only surgeon was one who combined the occasional exercise of that noble art with the daily and habitual flourish of a razor. To such a professional body Roger Chillingworth was a brilliant acquisition." The passage concludes with a remark that Chillingworth familiarized himself with antique physic, "in which every remedy contained a multitude of far-fetched and heterogeneous ingredients", many of such ingredients Chillingworth learned about in his Indian captivity. Chillingworth did not conceal from his patients that "these simple medicines, Nature's boon to the untutored savage, had quite as large a share of his own confidence as the European pharmacopoeia, which so many learned doctors had spent centuries in elaborating" (220).

These passages present several unclear clues as to which medical group Chillingworth belongs to; in fact, trying to classify Chillingworth is not the point as much as what he does with his knowledge. Chillingworth has a pedigree in the folk healing remedies of the Natives while possessing the knowledge of remedies as a homeopath. He even rebels from the treatments prescribed by the "European pharmacopoeia", a wink Hawthorne provides to gesture toward the allopaths, by prescribing the simple medicines. Despite that, it is significant that Chillingworth 
is trained as a scientist, not exclusively a physician, yet he presents himself as one. It is also significant that Hawthorne mentions how Chillingworth so easily assimilates himself into the American medical crowd because he assumes the role of piety and possesses a skill set only barbers possessed, seeing as how barbers helped with medical needs in Colonial America (David Dary). The significance of creating this effect is to illustrate how much Chillingworth resembled Hawthorne's current moment as homeopaths and other healers gained legitimacy following the repeal of medical licensing laws. While Chillingworth has training in homeopath-like remedies, Hawthorne does not appeal to the popular fears proponents of allopathy played to in his time as painting these sorts of practitioners as quacks or imposters. Instead of painting Chillingworth as a quack, he is a scientist with a special side interest in these country remedies. He is a sort of liminal figure made possible by the conditions of both Colonial and Antebellum America, a capable figure, an empirical scientist, who does not belong to any epistemic group with absolute certainty. Without a standard to hold these practitioners to, these physicians could be capable of anything, as Chillingworth would later prove as he uses his knowledge to corrupt Dimmesdale's spiritual well-being.

Like "Rappaccini’s Daughter," Hawthorne creates a blurred medical character who employs an overly personal gaze with his characterization of Chillingworth. Combining his hard feelings for Dimmesdale with his medical training creates in turn a physician whose stake in the patient becomes too much of a conflict of interest, and the removed conditions of New England allow Chillingworth to treat Dimmesdale despite the ethical quandary of treating him. Chillingworth is first introduced in the novel when he meets Hester upon her receiving the scarlet letter for the first time: "with calm and intent scrutiny, he felt her pulse, looked into her eyes,--a gaze that made her heart shrink and shudder, because so familiar, and yet so strange and 
cold..." (180). It is significant to note that in this passage, the reader is not yet aware of Chillingworth's connection of being married to Hester. Chillingworth again must treat a patient, this time his estranged wife, with the illusion of objectivity. Combining this illusion with objectivity with the intense feelings of anger Chillingworth felt thus results in a cold, freezing gaze, a gaze that makes Hester forget about the man she once knew along with a physician trying unsuccessfully to treat patients he should not be treating.

Chillingworth begins to cross the ethical line as he pieces together the fact that Dimmesdale was the man involved with Hester since he takes his role as a physician a bit too seriously when he moves in with Dimmesdale. Hawthorne's narrator takes special care to discuss how what should be an impersonal, clinician's gaze is made overly personal due to his monomaniacal feelings concerning Dimmesdale. As Hester meets Dimmesdale during the meteor scene, Chillingworth comes out of the house to observe them: "so vivid was the expression, or so intense the minister's perception of it, that it seemed still to remain painted on the darkness, after the meteor had vanished, with an effect as if the street and all things else were at once annihilated" (253). The meteor scene illustrates the fears of the physician growing overly invested with the patient in a medical culture dominated by empiricists whose role was to observe patients and have a bedside manner to be able to heal them effectively. Hawthorne creates an exaggerated, almost apocalyptic effect in describing Chillingworth's gaze as being hateful enough to destroy most all of creation. It then becomes too readily apparent that Dimmesdale's waning health, along with his spiritual force as a whole as the minister and religious head of the Boston body politic, is likely the result of Chillingworth's personal interest in his patient, an interest personal enough to cause Chillingworth to move in with his patient for the most hands-on care he can possibly give. 
After this incident, Hester meets with Chillingworth in private to discuss Dimmesdale's failing health, and it then becomes more clear that the temptation for revenge overcomes Chillingworth's ethical obligation as a physician to first do no harm. Chillingworth remarks to Hester of his relationship with Dimmesdale: "he knew that no friendly hand was pulling at his heart-strings, and that an eye was looking curiously into him, which sought only evil, and found it. But he knew not that the eye and hand were mine!" (266). Even despite this, Chillingworth notes that he attended to Dimmesdale's health despite his failing spirit: "but for my aid, his life would have burned away in torments, within the first two years after the perpetration of his crime and mine" (265). Furthermore, to further amplify connections made between scholars of Chillingworth to Milton's Satan, Chillingworth remarks that he was not always this way: "all my life had been made up of earnest, studious, thoughtful, quiet years, bestowed faithfully for the increase of mine own knowledge, and faithfully too...for the advancement of human welfare" (266). What we see from Chillingworth in this passage is an affirmation and confession that he only sought to corrupt the vital force of Dimmesdale; like Rappaccini, Dimmesdale had a secret poison that worked to only corrupt Dimmesdale's heart. At the same time, Chillingworth makes perfectly clear that if one was to look at the issue from a purely scientific and objective sense, he was able to care for Dimmesdale in a manner worthy enough to keep his body alive even though his spirit sinks. It should thus be again noted that in an age in which no organizational apparatus defined ethical rules for handling the dynamic between patient and doctor, the argument could be made that Chillingworth, despite his prejudices, manages to treat Dimmesdale effectively despite exerting a negative influence over his soul. However, Chillingworth treating Dimmesdale's material infirmities only increases his spiritual ones, resulting in a prolonged period of torment for Dimmesdale. The influence of empirical methods from homeopathy on Chillingworth's 
characterization thus demonstrates a change in representation as the physician now is overly invested in the patient, which contrasts with the depiction of the philosopher physician motif from allopathy as those physicians neglected the patient for philosophical gain.

Chillingworth, a scientist/physician existing in the liminal space of Colonial New England where he had no equals, can only perpetuate this ethical injustice in an American frontier culture devoid of any medical ethics since no licensing laws existed. Chillingworth would be alarming to the Antebellum American audience as the novel was published in similar conditions as physicians could practice with little to no oversight considering that allopaths faced a period of instability as they had not yet consolidated their forces into the American Medical Association. The reader cannot classify Chillingworth's medical allegiances because no clear organizational apparatus existed to demarcate knowers from nonknowers. No organizational ethical code existed to punish Chillingworth for his unethical care of Dimmesdale either. If the novel was published in the 1870 s instead of 1850 , Chillingworth arguably would thus not have the same ambiguous aura because the social conditions would not have realistically made sense for a character like him to arise. The fact that Hawthorne created so many characters with different medical interests suggests that Antebellum America struggled with classifying the differences between practitioners in an age where no organizational apparatus had yet to do so. Hawthorne's gothic form thus employed ambiguity to great effect seeing how

\section{III: Edgar Allan Poe's Unreliable 'Physicians?'}

The gothic works of Edgar Allan Poe that deal with medicine also comment on the medical establishment at large, both with allopaths and alternative practitioners. Like Hawthorne, Poe's fiction also had a significant interest in alternative forms of medicine beyond 
homeopathy, including phrenology and mesmerism, and as many scholars have mentioned, Poe had interesting ways of imagining health issues like mental illness before a proper vocabulary was even created to define these issues. ${ }^{4}$ Poe's works that take a gothic form work in much of the same critical ways as Hawthorne, especially in examining the overreach of the physician at the expense of the patient. Furthermore, Poe showcases fears about allopathic regulars being overzealous philosophers by placing the reader into a first person perspective, in turn forcing the reader into witnessing the doctor's monomaniacal tendencies even more directly than Hawthorne who presented these discourses through a third person, objective narrator. Poe's gothic raises a critique of medicine; however, just as with Hawthorne's gothic, it does not call for reform, but it does raise questions about classification as many of these physician characters had no clear medical allegiance. Nonetheless, the social conditions posed by the Jacksonian medical market provided a unique way of characterizing the overambitious physician, a way that would be duplicated by other artists in the century to come.

Poe's story "Berenice" is one of his most widely anthologized short stories, and as an exemplary example, it shows the unique social conditions of Jacksonian America as it illustrates the Jacksonian distrust for professional authority and elites through its characterization of its first-person narrator, Egaeus. In this story, Egaeus is not a physician in the traditional sense as he was an aristocrat raised on his family's estate, but he does resemble the popular fears about the overzealousness of allopathic physicians as philosophers interested in the pursuit of knowledge at the expense of the patient. If we combine this with Poe's characterization of Egaeus as an aristocrat, whom the populist Jacksonian audience would likely not trust, we thus see a story pertinent to American anxieties about nineteenth century medicine. The fact that Egaeus is not a doctor in fact only amplifies social concerns about how the patient was 
scrutinized for an illness as we see her condition deteriorate through the perspective of Egaeus, a philosophical outsider. Like Georgiana in "The Birthmark," Berenice is brought to the forefront of the tale because of how nineteenth century readers would perceive her vulnerability as a patient. As L. Kerr Dunn notes in her introduction to the tale, the "story urges us to ask questions about doctors' and scientists' attitudes toward and treatment of women and their bodies during the Victorian era, when "hysteria" was a catchall diagnosis used to explain many female illnesses" (148). Though Egaeus does not spell out that he is a physician, he may as well be one seeing how anyone could claim professional authority during this period. We see through his character the vulnerability of all patients in a medical market where the professional allopaths exhibited too much philosophical inclination at the expense of the patient due to the scope of their monomania.

Through his own account early in the tale, Egaeus, as a first-person narrator, provides his readers with ample details about the philosophical and theological education he received, and these details in turn provide the Jacksonian audience reason to distrust Egaeus's motivations with who would prove to be his patient. From the onset, he mentions how most of his childhood was spent in his estate's library, and there, he started thinking about the materiality of his soul: "there is, however, a remembrance of aerial forms — of spiritual and meaning eyes — of sounds, musical yet sad--...a memory like a shadow, vague, variable, indefinite, unsteady..." (225). He further mentions that he invested almost his entire boyhood in books, and his everyday reality became the world of dreams: "the realities of the world affected me as visions, and as visions only, while the wild ideas of the land of dreams became, in turn,--not the material of my everyday existence — but in very deed that existence utterly and solely in itself” (226) Significant about this passage is the sheer intellectual scope of Egaeus's character and the dangers of too much 
philosophical thinking for an 1830s audience. Egaeus is described in almost Platonic terms as he recalls perfect forms of sounds, and imperfect forms described like shadows. Like Aylmer in "The Birthmark," Egaeus speaks to the distrust of intellectuals in relation with the Jacksonian "Common Man," a distrust found in conjunction with allopathic regulars. Unlike Hawthorne, who portrayed this distrust through a third person narrator who would sometimes ask the reader to meditate on the doctor's ill-doing, such as with the end of "The Birthmark," Poe amplifies this theme through a direct account from Egaeus to create this distrust by having Egaeus spend so much time in what is an otherwise short story to provide these details. Reading a monologue like this from a first-person narrator adds to the reader's complicity in the tale. Unlike Hawthorne's third-person narrator, who moralizes for the reader, Poe's narrator directly puts the reader into the mind of the philosopher-physician to create distrust.

Poe also represents Egaeus's monomania through an overly invested personal gaze used to scrutinize someone with an illness, in this case Berenice; this gaze is fueled by Egaeus's philosophical speculations in metaphysics at the expense of Berenice herself. Berenice, Egaeus's cousin, only becomes an attractive prospect to him when she starts to suffer from her debilitating illness because of his idealistic visions. Egaeus notes that "during the brightest days of her unparalleled beauty, most surely I had never loved her" and that he had seen her abstractedly as "the Berenice of a dream — not as a being of the earth, earthy, but as an abstraction of such a being — not as a thing to admire, but to analyze — not as an object of love, but as the theme of the most abstruse although desultory speculation" (229). Egaeus also describes his approach to any philosophical problem as monomaniac, a "nervous intensity of interest" that "busied and buried themselves, in the contemplation of even the most ordinary objects of the universe" (227). Egaeus also name drops several books that he reads during his period of intense monomania, 
include the "treatise of the of the noble Italian Coelius Secundus Curio "de Amplitudine Beaiti Regni Dei;", St. Austin's great work, the "City of God;" and Tertullian "de Carne Christi” (228). What seems evident from these passages from a medical perspective is that Egaeus again thinks more as a philosopher than as a scientist, and as aforementioned, empiricists and homeopathic irregulars long criticized the allopathic establishment for being too philosophical. Also at stake here is the difference between philosophical, abstractive, deductive reasoning versus the inductive reasoning of treating disease through observation and experience. Egaeus looks at Berenice as an "object" fit for abstract speculation rather than as a human being fit to understand and observe through her experience. The name drop of the authors Egaeus reads further amplifies this effect, as Egaeus is most interested in metaphysics and theological academic disciplines most known for their reliance on deductive reasoning in pondering the mysteries of being. The problem with Egaeus is that he only has an academic interest in Berenice, just as many regular physicians likewise only treated their patients with the same outdated line of inquiry. This is again the same problem as some of Hawthorne's physicians, but this time the effect is further amplified by having the account come from the first-person narrator himself.

When Berenice starts to fall apart because of her debilitating condition, the only part of her body that does not degenerate is her teeth, and then for Egaeus his monomania sets in about them: "the teeth! - the teeth! - they were here, and there, and every where, and visibly and palpably before me; long, narrow, and excessively white, with the pale lips writhing about them, as in the very first moment of their first terrible development" (230) Thus Egaeus sets up the gothic nature of the tale as he fixates so much on the teeth that he cannot focus on anything else. Along with an acute awareness here of mental illness from Poe, we also see with Egaeus's fixation the dangers of philosophers as physicians. 
The tale ends with Egaeus realizing the horror implicit in his obsession as in an apparent memory haze he realizes he was the one who took Berenice's teeth from her, leaving her alive in the grave. He goes to Berenice's physician's toolbox to find thirty two perfect, white and ivorylooking substances "that were scattered to and fro about the floor" (233). What happens at the end of the tale as Egaeus realizes with horror his deeds is that Poe both calls attention to and at the same time reinforces the medical power structures in Jacksonian America by not quite indicting it. At the very least, the tale, by showcasing the privileged social position of Egaeus belonging to the aristocracy, raises alarm for a Jacksonian audience distrustful of elites. The fact that Egaeus, a philosopher, could perform medical acts by just acquainting himself with medical texts is extraordinary in that in the Antebellum American medical marketplace, figures like him could exist. Egaeus defies classification even more than Chillingworth considering he has zero medical training. We thus see again with this tale the gothic forecasting a range of alarming possibilities: Egaeus embodies traits from both allopathic regulars and homeopaths because in the free marketplace, these lines became blurred themselves. Poe's gothic tale thus draws attention to this problem without taking a stance in favor of the profession or alternative healers, but it does raise the issue that clearer definitions need to be established.

An important distinction to make about Poe's story compared to Hawthorne, as this story closely resembles "The Birthmark" is with his characterization of the patient. Berenice never factors into the story beyond being a passive agent who degenerates in the eyes of Egaeus; she never gets a line in the story as Georgiana did in "The Birthmark." This was no fault in Poe's lack of characterizing her; with Poe, we see even more explicitly that the patient is the one who suffers at the hands of the unstable medical market. Berenice's absence in the story compounds the fact that the patient is but a means to an end as physicians saw them more as philosophical 
test subjects than as people with illnesses. This theme only compounds itself in other Poe stories as more attention is spent on the patients; lack of autonomy is evident since the physician serves as the first-person narrator. Unlike the tales of Hawthorne, where the third person narrator could comment on the doctors' wrongdoing, Poe's narrator does not allow this introspection, which further exacerbates the divide between doctor and patient.

We see questions of ethics concerning the patient again arise in Poe's story "Facts in the Case of M. Valdemar" where Poe again complicates the distrust of medical authority by incorporating a first-person narrator. This story also explores the popular fears about another alternative medical practice - mesmerism - a medical practice explored by Hawthorne in The House of the Seven Gables and The Blithedale Romance as well as by British gothic writers in works like Richard Marsh's The Beetle. Poe also contributed a number of other stories related to mesmerism, many of which extend beyond the boundaries of the gothic form. With M. Valdemar, the culpability of the patient is again explored here by Poe, and Poe was so successful in his execution of the tale in its documentarian style of prose that many readers at the time accepted the story as fact rather than fiction upon reading it (Dunn 255). The story's plot is simple: a patient with tuberculosis, M. Valdemar, is on his deathbed when he consents to being put into a state of mesmerism for scientific experimentation. Valdemar remains mesmerized for a period of months in the story when, upon questioning, he admits that he is in fact dead but his soul remains trapped by the mesmeric influence. The story ends with the physician breaking the mesmeric link and with Valdemar's body turning into dust, and this frightening display in turn raises questions about the implications of mesmerism.

As previous scholars have mentioned, part of the alarming nature of this tale to nineteenth century audiences is due to the scientific, almost technical language that Poe's 
narrator expresses; this analysis posits however that this language serves as a tool of showing how the patient was but a mere part of an experiment, a test subject rather than a person who needed the most ethical care possible. Early in the text, when describing Valdemar, the narrator describes him almost like a lab rat that he would use for testing purposes: "his temperament was markedly nervous, and rendered him a good subject for mesmeric experiment...I knew the steady philosophy of the man too well to apprehend any scruples from him; and he had no relatives in America who would be likely to interfere" (834). Furthermore, the doctor goes to great detail to describe Valdemar's tuberculosis to the reader in scientific terms: "the left lung had been for eighteen months in a semi-osseous or cartilaginous state, and was, of course, entirely useless for all purposes of vitality. The right...was also partially, if not thoroughly ossified" (835). He continues by noting that "the ossification had proceeded with very unusual rapidity; no sign of it had been discovered a month before, and the adhesion had only been observed during the three previous days" (835). This sort of technical language served to alarm readers in Poe's day both because it seemed like a real doctor but also because in the unstable medical market where people looked for any sort of answers they could find, they saw a physician here describing a patient as a mere test subject in a language inaccessible to the public. By using technical terms like "semi-osseous or cartilaginous state", Poe describes the medical condition in a way more fitting for specialists; Poe published the story in the American Review: $a$ Whig Journal, a journal that based on its political stance was not synonymous with Jacksonian Democrats but, if read by Democrats, would remain off-putting. Herein also is a case in which the patient is put on blatant display for the reader, the patient being the forefront of analysis both for the physician and the reader. This, along with the title of the story, illustrates that while the 
physician is the documentarian, this analysis is about the patient even more so than the unnamed physician and even more than the alternative methodology he espouses.

Much of the ambiguity of this story revolves around the issue of Valdemar's consent to be part of this experiment; with issues revolving around mesmerism, questions concerning the patient's consent frequently arose. The doctor argues early in the tale that part of the reason Valdemar is an attractive patient is because he has no family to object to the experiment; in turn this raises questions concerning whether Valdemar is being exploited or not. As Valdemar grows closer to death, the narrator fears embarrassment for the experiment and grows wary of who might be there to witness the experiment: "a male and a female nurse were in attendance; but I did not feel myself altogether at liberty to engage in a task of this character with no more reliable witnesses than these people, in case of sudden accident might prove..." (836). Thus, he delays operations "until the arrival of a medical student with whom I had some acquaintance...relieved me from farther embarrassment" (836). Furthermore, when Valdemar is on his death bed, the narrator asks him for his consent to be mesmerized, to which he notes, "Yes, I wish to be mesmerized...I fear you have deferred it too long" (836). These passages at the very least raise the question of the patient's role within these experiments. While the text would not suggest that Valdemar was not informed of the experiment beforehand, his helplessness as a patient to change his mind is apparent without the lack of family or without a witness around who might question the doctor's credibility. At the very least, the fact that Poe takes such special pains to show the patient's consent, and then later in the story show how the experiment goes horribly wrong for Valdemar, illustrates the problematic nature of patient consent when they are at the mercy of a mesmerist and cannot exert their will into the situation. While the doctor even later brings in other doctors to observe the final death knell, they must 
take the narrator's word for granted in going about the issue of the patient's concept: "when Doctors D--- and F--- called, according to appointment, I explained to them, in a few words, what I designed, and as they opposed no objection, saying that the patient was already in the death agony, I proceeded without hesitation..." (836). The fact that these doctors are even committed to the trial illustrates the point that they too value the progress of scientific knowledge perhaps even more so than the patient in not fully committing to knowing whether Valdemar consents.

Beyond the notion of consent because of the mesmerism, the tale goes to great lengths to show the extension of suffering Valdemar must endure to die peacefully. The experiment indeed suggests that the mesmeric act holds Valdemar's soul hostage from being able to leave the body, or at least whatever sort of magnetic essence holds his body in place for this long. The moment of Valdemar's death showcases an unspeakable horror of his face upon death: "so hideous beyond conception was the appearance of M. Valdemar at this moment, that there was a general shrinking back from the region of the bed" (839). Valdemar's voice also remains intact, though in a horrific sound beyond understanding. Upon trying to revive Valdemar after a seven month period of time, they struggle to revive him and then find that the lowering of his pupil in the act of examining him was "accompanied by the profuse out-flowing of a yellowish ichor (from beneath the lids) of a pungent and highly offensive odor" (841). The suffering Valdemar endures is also evident when asked about how he feels about his condition, where he proclaims: "For God's sake!—quick—quick!—put me to sleep—or, quick—waken me!—quick!—I say to you that I am dead!" (841). We thus see that lost in this grand experiment is Valdemar himself; the implications of what this study means for him arguably go far beyond the bounds of consent, and even if legally they do not, the medical ethics must be raised into question. It must again be 
noted that even if this story was fact, not fiction, only the unstable medical climate of Antebellum America could have given rise to such a climate with the patient at the margins. Poe again illustrates with this story the negligence toward the patient for the sake of scientific experimentation.

\section{IV: Concluding Thoughts: The Gothic Physician in H.P. Lovecraft and Beyond}

While the Jacksonian disdain for elitism contributed to informing the gothic in the Antebellum era, both medicine and political conditions changed following the Civil War. Allopathy, with the rise of the American Medical Association, grew in legitimacy both as an epistemic force and because the Federal Government, despite having a critical shortage of physicians, barred any alternative practitioners from practicing. The aftermath of the Civil War also gave rise to new literary modes that became more prominent than the Gothic, including realism and naturalism. As we know from the likes of Henry James, prominent literary artists even combined elements from the gothic into other modes. With the decades after the Civil War came with them different social concerns that those other modes processed.

The gothic fiction of Howard Phillips Lovecraft is known for its exceeding nihilism with his creation of the Cthulhu mythos: a series of short stories featuring protagonists who discover and reawaken beings that go beyond the scope of the human imagination. His fiction also speaks to Lovecraft's own conservative impulses in the 1920s and 1930s, particularly to a xenophobia against African Americans and immigrants. Nonetheless, his works inspired a new generation of readers, and Lovecraft's own literary reading led to an affinity for eighteenth century British literature along with the Antebellum gothic works of Poe. Lovecraft's passion for the gothic led to the creation of one of his lesser-known stories, "Herbert West—Reanimator," a story more 
likely known by its 1980s adaptations into film than the story itself, serialized over a number of years by Lovecraft into magazines. The story's premise is simple: West, a young medical student, finds that he can reanimate corpses with a serum he invents moments after the patient's rigor mortis. What happens then is a Frankenstein-like story as West must deal with the implications of his actions over a long period.

Lovecraft's story showcases a similar Jacksonian fear of elites extended into the twentieth century with his creation of West as an overzealous physician with no concern for the patient. From the onset of the tale, the narrator, West's accomplice, describes him as a man intent on medical experimentation at the expense of numerous nonhuman subjects: "in his experiments with various animating solutions he had killed and treated immense numbers of rabbits, guinea-pigs, cats, dogs, and monkeys, till he had become the prime nuisance of the college" (24). Furthermore, the narrator describes West with the same cold, objectifying gaze that Hawthorne had used to describe Aylmer: "he was small, blond, clean-shaved, soft-voiced, and spectacled, with only an occasional flash of a cold blue eye to tell of the hardening and growing fanaticism of his character under the pressure of his terrible investigations" (40). With West's gaze comes with it his inability to process the plight of his patients: "his interest became a perverse addiction to the repellently and fiendishly abnormal; he gloated calmly over artificial monstrosities which would make most healthy men drop dead from fright and disgust..." (46). In short, Lovecraft created with West the same nineteenth- century physician that we saw with Hawthorne and Poe.

Lovecraft had his own historical conditions to inform his tale. The destruction of lives caused by World War gives West a chance to find fresh and even dying bodies to experiment on for the sake of his scientific, and philosophical advancements into the nature of life. Allopathy's 
acceptance of the science of bacteriology also informs the story, as West works to reanimate the cells, even going as far as to use Reptilian cells that regenerate to experiment on his patients (47). Lovecraft's own xenophobia against African Americans also arises in the tale where the narrator describes one of the reanimated subjects as a "loathsome, gorilla-like thing, with abnormally long arms which I could not help calling fore legs, and a face that conjured up thoughts of unspeakable Congo secrets and tom-tom poundings under an eerie moon" (37).

While many of these factors also contributed to Hawthorne and Poe's era, Lovecraft contributions to the gothic applied the same Jacksonian-era disdain for elites and the philosophy's applicability to the average white man to the twentieth century decades after Hawthorne and Poe's era. Lovecraft's doctor speaks to similar social tensions as Hawthorne and Poe's time even as the characterization of West is arguably even more critical considering that professional authority, allopathy, regained much of its legitimacy in Lovecraft's time. The gothic physician persists even in our late twentieth and twenty-first century popular culture, ranging from the numerous Reanimator adaptations to the overzealous Dr. Arden in the popular television show American Horror Story. The nineteenth-century medical gothic, and the populist fears it represented, seem to be here to stay. 


\section{Notes}

1. Critics like F.O. Matthiessen extoled the genre as "manifesting a 'mechanical horror' that was overcome in the 1840s and 1850s by an overwhelming American idealism (qtd. in Hogle 4). Harry Levin in The Power of Blackness asserted that "the affinity between the American psyche and the Gothic romance" is rooted in a "union of opposites basic to the American outlook' (xi) in which there are hesitations between tradition and modernity" (qtd. in Hogle 4). Leslie Fielder applied psychoanalysis to the gothic by looking at the genre as processing "the guilt of the revolutionary haunted by the (paternal [European] past he has been striving to destroy"; this includes the fear of destroying old ego-ideals like Church and State and thus regressing into the maternal womb of the dangerous new frontiers of works like Brockden Brown's Edgar Huntly (qtd. in Hogle 6). Identity critics have fostered how the gothic forces unconventional personal, sexual, and emotional behaviors and attitudes into situations that "threaten conventional perceptions with their fear-inducing alterities" (11).

2. Stephanie Browner's chapter “ Reading the Body: Hawthorne's Tales of Medical Ambition" is a similar albeit different reading. Browner conceptualizes Georgiana's treatment as a patient from Aylmer through Foucault's definition of the clinical gaze, in which "knowing the body and knowing when it was healthy or ill became a matter not of listening to the patient's story but of fixing an impersonal, clinical gaze upon the body. Disease supplanted illness as the primary focus of therauputics"; in short, through this system, the "modern body is thus a generic body, known through statistical studies, anatomical atlases, and mathematical averages that have erased the idiosyncratic and the particular" (31). Browner argues that the horror of the tale thus arises from this 
impersonal gaze on the exposed female body. Another important reading is from Taylor Stoehr's 1976 book Hawthorne's Mad Scientists, where she argues that Aylmer is a homeopath who treats Georgiana through pharmaceutical means, as Aylmer tries to cure the birthmark by using poisons for healing purposes. Stoehr's project conceptualizes characters through scientific and pseudoscientific movements at the time, but my project differentiates itself from hers as classifying Aylmer as more of a hybrid medical figure whose treatment is homeopathic but whose application is allopathic.

3. In his 1976 dissertation, David Stooke characterized Chillingworth as a "scientist who is dedicated to the curing or relieving of pain" (43). Taylor Stoehr asserted in her 1978 book Hawthorne's Mad Scientists that Chillingworth was a homeopath not only due to "his patient researches into the virtues of the herbs he collected in the forest, but also in his insistence on treating Dimmesdale's peculiar disease at its sources" (104). Chillingworth's attempt to cure the "vital force" of Dimmesdale would resemble homeopathy, despite the fact Chillingworth only attempts to corrupt his vital force more. Most recently, J Dolezal, a physician, attempted to show all the differing medical sects Chillingworth could have belonged to in Nineteenth Century America in his article "The Medical Palimpsest of The Scarlet Letter: An Interdisciplinary Reading", including as an iatrochemist, a herbalist/homeopath, and as a clinician/allopath.

4. L Kerr Dunn sums up most of this scholarship in his introduction to Mysterious Medicine: The Doctor-Scientist Tales of Hawthorne and Poe. He mentions that in a 2001 article, Brett Zimmerman argued that Poe provided a "case study of paranoid schizophrenia in "The Tell-Tale Heart decades before schizophrenia was named or understood as a discrete mental illness" (8). Likewise, Altschuler and Augenstein have 
argued that Peter Pendulum in "The Businessman" exhibited signs of "frontal lobe syndrome before the famous case of Phineas Gage put the syndrome on the map" (9). 
Chapter 2: The Politics of Medical Professionalization \& Realist Form: A Study of Howells,

$$
\text { Phelps, and Jewett }
$$

\section{I: Introductory Remarks}

In his remarks on the aesthetics of American Realism, the literary mode he championed, William Dean Howells theorized what set Realism apart from other genres, and he also defined what the ideological significance of "Realism" was. Of all criteria, the realist novel's endeavor for truth appealed to Howells: "I make truth the prime test of a novel. If I do not find that it is like life, then it does not exist for me as art; it is ugly, it is ludicrous, it is impossible" (905). Howells admits, however, that no objective truth exists; truth is subjective: "the truth which I mean...is truth to human experience, and human experience is so manifold and so recondite, that no scheme can be too airy for the test...imagination can work only with the stuff of experience" (906). During this Gilded Age, a time full of competing visions for the burgeoning nation's future, Howells was not unique in asking the basic epistemological question: what is truth? And if truth is subjective, then how can one adhere to it in literary practice?

Social fiction thus raised the question: whose perspective is 'real' or perhaps the most credible among several stakeholders? The medical profession was one subject among many to which the realists were drawn, and it was a profession that post war maintained a number of stakeholders; these included allopathic regulars who aspired to form a professional middle class, professional women who sought to enter that middle class, all forms of alternative medicine, along with the patients who navigated what was still a tumultuous medical market even as it was standardizing Allopathic regulars again regained their privilege and status by defining their profession and refusing to work with any outsiders. Like the Antebellum era, fiction took up the 
subject of medical professionalization; however, unlike that period, allopathic medicine had found its footing and regained its legitimacy with the public in the years following the Civil War.

Like the constant epistemic struggle between allopathy and alternative practices, American Realism faced several challengers in the literary marketplace, ranging from the gothic romances of Hawthorne to a literary marketplace dominated by women whom writers like Howells and James perceived as writing overly sentimental fiction. Regarding the antebellum romance, the dominant sect of realism appreciated works from Hawthorne and others but nonetheless saw them as aloof from the social world. ${ }^{1}$ Regarding the latter, David Shi notes that "self-conscious realists—whether male or female—especially gagged on the jab of sentimentalism. Of all the literary sins, it most aroused their contempt" (111). It did so as appeals to pathos encouraged people, as the literary critic Henry Seidel Canby argued, to "dodge the facts of life - or to pervert them" (qtd in Shi 111). Howells and James perceived these 'sentimental' novels as "a pabulum of cheap pathos and false role models that encouraged them (women) to accept self-sacrifice and quiet suffering as their only outlets for self-expression" (112). While many of these 'sentimental' novels have not survived in the literary canon, they had enormous popularity in their day, and some texts remain canonized despite many literary critics' disdain for sentimentality; some popular names include Stowe's Uncle Tom's Cabin, Davis's Life in the Iron Mills, and Maria Cummins's novel The Lamplighter. .

Realists also raised questions about the literary and commercial merit of their work. How is realism art? Amongst many alternatives, why would readers be interested in a mode grounded in reality, a mode that doesn't allow for the escapist appeal of literature that other modes do? David Shi mentions that unlike a photograph, which captures the objective fidelity of a thing as it is, realism is a product of the "probing imagination. The realistic writer started with facts, but 
the details must somehow be endowed with life — and with art" (120). Shi argued that in an everexpanding literary marketplace, many middle-class readers gravitated towards realism over the other modes; these readers "wanted stories they could relate to, stories that would help them make sense of their own lives, stories that featured recognizable people making difficult choices" (110). With the increasing public turn toward professionalization in many professions, medicine notwithstanding, in the late nineteenth-century, it is thus not a surprise that realism attempted to document and imagine it. Four medical novels fit within this umbrella in the waning decades of the century: Howells' Doctor Breen's Practice (1881), Elizabeth Stuart Phelps's Doctor Zay (1882), Sarah Jewett's A Country Doctor (1884), and Annie Meyer's Helen Brent, M.D.: A Social Study (1892).

This chapter builds off previous scholarship, a body of work that will be mentioned in the next section, to examine the ways these four novels imagine, through the limitations of the form, the ideologies surrounding the political movement to standardize the profession. This argument illustrates how differing authors from varying backgrounds all used common traits of form-an emphasis on didacticism, community building, and a marriage plotline - to represent how medical professionalization does and will continue to function in the burgeoning new American medical marketplace. These novelists all engaged with ideals of the realist form espoused by its dominant voices, Howells and James, most notably the idea of a formal unity, or symmetry, tying together a series of discordant threads and plotlines. Phelps and Jewett operate within these parameters; however, within the forms, they found considerable freedom to find a unity that was truer to their perceptions of reality. This chapter examines how the three novels written by women differ in function from the ideology of the masculine realism of Howells by either maintaining or bending the formal conventions in new ways. This analysis follows critically 
from what Fredric Jameson has coined as mediation; social life is "in its fundamental reality one and indivisible, a seamless web, a single inconceivable and transindividual process" (39-40); interpretation is thus "not an isolated act, but takes place within a Homeric battlefield, on which a host of interpretive oppositions are either openly or implicitly in conflict" (13). In this chapter, these authors all competed with one another on such a Homeric battlefield regarding the politics of professionalization along with nineteenth-century gender roles for women. What is at stake is how and to what extent the three female novelists all created a politics of resistance to the dominant paradigm of Howells even while upholding many of the conventions of form he promoted. These novels illustrate several competing ideologies at stake in a fiction grounded in reality; realism thus is able to both imagine and synthesize debates from various perspectives about medical professionalization within the confines of its form.

Alongside the form, the social function of these texts also matters, and at stake in this chapter is to what extent the varying authors twisted the form for their varying functions. Regarding William Dean Howells' Dr. Breen's Practice, this analysis concurs with Amy Kaplan's analysis of realism, where she spends a couple of chapters on Howells. She notes that realism generally "is a conservative force whose very act of exposure reveals its complicity with structures of power" (1). The mode both imagines and manages "the threats of social changenot just to assert a dominant power but often to assuage fears of powerlessness" (10). She mentions that realism synthesizes these threats as "they appear as the potential for revolutionary upheaval" (20). The realists not only construct and organize the social world as they see fit but also "by containing the threats of social change, realistic narratives also register those desires which undermine the closure of that containment" (10). Kaplan's analysis regarding the function of Realism is applicable to Howells' medical novel as it, like the others, represents popular fears 
about women practitioners; these fears range from their inability to function as housewives if they work to a Victorian sense of propriety in that working is not proper behavior. Howells solidifies the white male professional middle-class, as Dr. Breen falls in love, thus exiting her profession, along with ceding care of her patient to the male allopath who refuses to practice with her because of professional ethics. This ending resolves the revolutionary potential for both women to upset the marriage market along with the notion that she, as a homeopath, can provide adequate care for her patient; proper care is restored to the allopathic practitioner by novel's end. We thus see a difference between a male-dominated profession, allopathy, versus a femalecentered alternative founded on patient care, homeopathy. At the same time, through the realist form, the novel registers the revolutionary potential for opening the middle-class to outsiders; this potential would then be revealed and imagined further through Howells' female contemporaries.

In some respect, all these novels explore the aesthetic implications of didacticism as they all deal with the implications of women entering the medical profession. Howells did not believe in didacticism because he associated didacticism with sentimental writing. Because Howells focuses on character above all else, these characters would thus lack agency, characters who are "painting dolls" that are worked by "springs and wires" for the work's political purpose (Shi 119). If Howellsian realism reiterates the ideology of the emerging, masculine middle class, then no need for didacticism existed in doing so as the novel synthesizes the novel's political implications without needing narrative intrusion. Howells does, however, create a didactic character in Miss Gleason, but he characterizes her as a character with an overbearing and overreaching sense of fancy that is not grounded. The women realists, in a politics of resistance to the ideological ramifications of Howells' fiction, all inject didacticism into their works to 
varying degrees. Phelps's Dr. Zay does so through the sheer amount of details provided on Zay's competence along with the dull nature of her suitor; therefore, her forthcoming exit from the profession by novel's end after her reluctant agreement to marry illustrates a tragedy of sorts in that rural Maine will inevitably lose one of its finest practitioners, a doctor who understands its people, for a marriage that is doomed from the beginning. Jewett believed that her fiction needed "moral messages in the form of silent scripture" meaning that it's acceptable for a novel to fall within the political realm. The competence of her physician, Nan, to be a valuable member of her profession speaks for itself without as much need for the narrator's interjections. While the others appreciate didacticism while maintaining some level of ambiguity, Meyer's novel Helen Brent, M.D is so didactic as to be overtly political; in this way, her novel stands out as a point of contrast as it has little in common with Howellsian realism.. Meyer's narrator frequently intervenes throughout the text to make emphatic statements regarding Dr. Brent's competence along with emphasizing the ignorance of the men who want women to leave their careers to become housewives. Meyer's text borrows from the sentimental tradition by employing didacticism, yet Meyer inverts the objections raised by Howells and James by empowering her character's choices rather than suffering silently as a melancholic martyr.

All these writers also share an interest in community building in their medical fiction; most notably, all of them share a common concern for the standards of care provided to members of rural communities. In his study, Mark Storey noted that "the depersonalization of narrative voice in literary realism distances the reader from the origin of production, in the same way that one of the dominant shifts taking place 'between the 1870s and the early 1900s' is that the social distance between doctor and patient increased" (91). In an era of increasing industrialization with rapid growth in urban areas, and in an era in which allopathy dominated in urban areas, 
realism concerned itself with the rural implications of professionalizing medicine and allowing women into the profession. Significant about this is that all the writers but Meyer construct a homeopath, thus suggesting that in this rural economy, a patient-centered approach is preferable; however, each character has a narrative arc tying them to urban areas and urban medicine. In this way, we also see a male-dominated allopathic profession pitted against a female-centered homeopathic one, and this put into conflict two differing ways to care for patients. Howells keeps the status quo since his Dr. Breen lacked significant resolve in her profession, so her imminent marriage to an industrialist keeps the rural community whole. Phelps constructs a protagonist, Dr. Zay, who is integral to her rural Maine community; therefore, when she decides to marry her suitor, a professional lawyer from Boston, Zay's community is left fractured by her imminent absence. Jewett's doctor, Nan, trains under an allopath as an apprentice, yet her interests extend toward homeopathy. However, despite her talents, Nan must go to Boston to get medical training, suggesting in turn that the middle-class move toward professionalization was a cosmopolitan trend at odds with the pastoral lifestyle of small-town communities. Nan does, however, reject the urban lifestyle from her newfound relationship with his father's family in rejecting a suitor her aunt introduced her to and returns home to her original rural community. The marriage plotline anchors all these texts as the women practitioners negotiate their professional duties with their personal love interests. This plotline thus creates similar narrative devices in each text. All the women face internal conflict over duty versus romance, as the third person omniscient narrators note, along with conflict with members in their community; some of these members argue for remaining a medical professional and some do not. None of these texts endorse the idea that a woman can both marry and be a diligent member of the profession; it is one or the other. Both Phelps and Meyer create physicians who make arguments to their love 
interests that they cannot negotiate both their professional duties along with work responsibilities at home. Howells has an allopathic physician propose marriage to Dr. Breen, even offering to move west with her so both can practice medicine without overly imposing state regulation since he could not consult with a homeopath; however, Dr. Breen rejects this solution in favor of her marriage to a wealthy young industrialist. Jewett spends almost a third of her novel on Nan's growing relationship with her suitor, but Nan rejects marriage in favor of her professional obligation toward her patients.

By using these similar conventions, all the writers surveyed had their own perspectives on how a realist text could accurately represent their female doctor's agency in various types of determinist webs. Unlike naturalism, where the determinism is fixed in creating an uncaring, indifferent universe where larger social forces act at odds with the characters, realism focuses more on how all these characters negotiate with and find agency in an America that was solidifying varying types of superstructures. With regards to medical professionalization, these characters negotiate with the growing superstructure of professionals unifying into a middleclass with set rules and boundaries. Another type of determinism that governs these novels is a gendered one as all the women with varying social backgrounds must negotiate whether they can enter into this middle-class because of customs like the marriage market. Whether or not these doctors choose to marry has implications for the profession because these women are continually persuaded not to practice because of their partner's class status or because the demands from being a credible doctor would countermand traditional gendered roles from their partners.

All the elements of realist form discussed in this chapter have implications for the function of realism, a mode that has been read as a "conservative force complicit with capitalist relations" (Kaplan 7) and one that through its engagement with chance supported "emergent new 
forms of social organization" (Puskar 1). In his realism, Howells obsessed over the idea of a type of formal symmetry where all plot threads neatly tie together. In an interview with Stephen Crane, Howells noted that the novel is a perspective, one "made for the benefit of people who have no true use of their eyes. The novel, in its real meaning, adjusts the proportions. It preserves the balances. It is in this way that lessons are to be taught and reforms to be won" (From Novel Writing \& Novel Reading). Furthermore, Howells notes that if a reader can accept details as true, the writer's task is to "arrange a correct perspective, in which all things shall appear in their very proportion and relation." James, the other dominant voice of realism, shared the same idea: "the exquisite problem of the artist is eternally but to draw, by a geometry of his own, the circle within which they shall happily appear to do so" (qtd. In Davis 99).

This idea of formal unity and preserving the balances supports Kaplan's point of realism's political function remaining complicit with capitalist relations; in his medical novel, Howells endorses the status quo - a male dominated, allopathic profession, at the expense of his heroine. This chapter thus examines how writers from varying social backgrounds engaged with the demand for symmetry that was a limitation for writers who subscribed to the realist mode. Because the logic of middle-class professionalization is at stake in every work, these writers' engagement with narrative symmetry thus all presented varying social messages with changing social functions for their readers. When traditional ideas are subverted by writers who engage with the realist form, and when the novels retain a sense of symmetry in doing so, which is most demonstrated by Jewett's “A Country Doctor," realism demonstrated a revolutionary populist potential in opening the medical profession, and by extension the middle class without the need for pre-existing status, to women, which in turn opens more of a patient-centered approach that exists at odds with male-dominated, laboratory-focused allopathy. 


\section{II: Contexts: Historical}

Allopathy's return to prestige had several causes, factors both before, during, and long after the Civil War. ${ }^{2}$ While allopathy gradually ascended to public prominence, it was a white male dominated profession. The decades following the Civil War saw a temporary increase in the number of female practitioners; however, it proved to be a short trend. Michael Sartisky notes several factors regarding women entering the profession, reasons extending back to Colonial America. He quotes historian Mary Walsh, who noted that in Colonial America professionalization "did not develop in an ideological vacuum. Rather, its evolution was shaped by the sexual biases within American society" as the colonies were founded on "a strong patriarchal foundation, and female opportunities outside the home and family have been circumscribed ever since" (271). Beyond this reason, Sartisky notes that midwifery was an unofficial profession of sorts for women, and the advancements in allopathy caused a significant decline in infant mortality, putting women out of jobs and thus further consolidating the profession for males (276). Above all, even though women found admittance to medical institutions like Johns Hopkins and Tufts, the number of women in the profession drastically declined after 1910, the year of the Flexner Report. ${ }^{3}$ Sartisky mentions that once the institutionalization of allopathy became more formalized, women yet again were excluded because the years of progress women reached were due to the immature state of the profession, and with Flexner, the profession found a "structural means to assert itself in the medical sphere" (278). What is significant about this timeline to the novels discussed in this chapter is that all of them fell at a moment, the 1880s, when women did gain some ground in the medical marketplace and were engaging with the public sphere about their role as professionals, and these realist novels helped to both reinforce and subvert older ideologies. 
Another issue that affects how realism treated the subject of medical professionalization was the issue of urban versus rural medicine. These novels feature women as the main protagonists who work in the country and not in urban areas. In general, allopathy and urban medicine were synonymous. Mark Storey argues of the period that "materially, a modern, scientifically grounded and institutionalized medicine finds its home in the city simply because the city provides the density of people most conducive to developing bodies of knowledge" (86). With regards to how urban medicine operates in rural areas, Storey notes that the city was "the originating site of an increasingly incorporative and nationalized standard of medical knowledge" (86). Rural areas typically resisted this standardization and these emerging new power dynamics. As allopathy allied itself with bacteriology, it became more laboratoryoriented rather than patient-centered branch of knowledge; therefore, homeopathy, despite losing its ethos in urban branches, still thrived in rural areas. The richest Americans in the city also still favored homeopathy due to its more patient-centered methodologies. In their novels, Phelps and Jewett blurred the distinction between the two sects as both homeopaths and allopaths merged into a "country-doctor" figure, a liminal figure that struggles to coexist as she balances the divide between the urban middle-class and the rural lower classes. Realism thus offers a unique way of imagining this divide when certain authors subvert the traditional forms based on their own ideologies in characterizing these figures.

\section{III: Literature Review on American Realism}

A critical history of American Realism is in order to illustrate how this chapter fits within the breadth of the larger scholarly conversation on the form and function of the mode. New Critical approaches to Realism often found the aesthetic quality of Realism lacking. Of this generation of critics, Amy Kaplan notes that "stylistic inconsistencies and problematic endings 
were treated as internal formal flaws rather than as narrative articulations of ideological problems" (5). Leo Marx's "Mr. Eliot, Mr. Trilling, and Huckleberry Finn" illustrates this generational tendency by showcasing how much Twain differed from the norms: "the flimsy devices of plot, the discordant farcical tone, and the disintegration of the major characters all betray the failure of the ending" and the book "has little or no formal unity independent of the joint purpose of Huck and Jim." These critics saw unity as an aesthetic ideal. Seeing how their lens looked at literature as apolitically as possible, they did not find this ideal through purely formal readings; thus, realism struggled to gain any legitimacy in the canon.

The rise of the New Historicism revived realism as a literary genre as the literariness of the text was not emphasized as much as to what extent a text reflected an ideology—-those "unspoken collective understandings, conventions, stories, and cultural practices that uphold systems of social power" (Kaplan 6). Rather than disassociating politics with literature as the generation before them had done, these critics treated realism as "a social practice... realists do more than passively record the world outside; they actively create and criticize the meanings, representations, and ideologies of their own changing culture" (7). While other modes like the gothic treated social problems, realism directly imagined them without the guise of ambiguity. As aforementioned, Kaplan is one of the most prominent critics of the New Historicists in her argument that realism is a "conservative force complicit with capitalist relations" (7). A few other studies revived realism as well since the political dimension of literature was now appreciated. In his book Conscience and Purpose: Fiction and Social Consciousness in Howells, Jewett, Chesnutt, and Cather, Paul Petrie discusses the pervasive influence William Dean Howells had on all these writers with his emphasis on fiction being a sort of public duty: "whatever their differences from each other and from Howells—and there were many - these 
three writers' fictions were shaped by their interactions with Howellsian ideas about fiction's social-ethical duties and the artistic mode(s) best suited to fulfilling them" (XI). Because Howells' form of realism was so engrained in the social fabric of everyday American culture, the New Historicism thus found an ample subject in a fiction directly tied to politics.

Although the New Historicists did much to revive realism's place in the American canon, their critiques of the text's ideologies, the function of the texts, does not come without some criticism of its own. Much of this criticism has come from Feminist Criticism of the medical novels from the period. In her book Bodily and Narrative Forms: The Influence of Medicine on American Literature, 1845-1915, Cynthia Davis argues that "new historicists often textualize context with too little regard for the literariness of the literary artifact and with too much regard for how narrative content (and content alone) reflects social context" (5). Davis notes that without doubt literary works engage in social debates, but literary scholars need to ask not only what authors represented but how they represent it (2). This criticism has led to a long line of productive work on how the form of realism relates to its function. In his book Accident Society: Fiction, Collectivity, and the Production of Chance, Jason Puskar takes a public dialogue about chance, especially in a time of rapid industrialization and urban expansion and argues that authors "produced chance in new and specifically modern forms through narratives of spontaneous and blameless violence and that those narratives in turn supported emergent modes of social organization" (1). Realist texts in general, Puskar argues, inflamed fears of chance accidents happening, because the more indeterminate the universe seemed to be, the more new modes of social organization could then happen. Both Davis and Puskar take up different topics in their study of American Realism; however, both scholars demonstrate a commitment to studying ideology without ignoring form. 
This chapter builds off this body of work in examining to what extent realist writers engaged with the ideologies of medical professionalization, and the social issue of medical professionalization has not yet been touched on in discussions of these novels. Davis builds her study on examining how medical fiction treated the subject of the female body; other studies since hers, including Stephanie Browner's book Profound Science and Elegant Literature: Imagining Doctors in Nineteenth-Century America, mostly focus on how these novels represented the body. This analysis thus emphasizes the social implications and dialogues regarding building and maintaining the emergent new class of medical professionals; however, in doing so, this chapter aspires to continue the methodology Davis, Puskar, and others have developed in combining a discussion of form while not forgetting about growing social concerns.

\section{IV: Protecting the Profession in Howells' Dr. Breen's Practice}

Whenever American Realism is written about and taught, William Dean Howells is always a personality subject for discussion through his sheer influence as both a writer and his work as editor of The Atlantic Monthly along with his column Harper's Editor Study. At the time when Howellsian realism was prominent, the middle-class found its footing even as the nation's wealth was gradually distributed to the upper classes and the industrial capitalist figures such as Carnegie. Howells himself was an exemplar of a rags-to-riches, American dream type of story; Howells spent his formative years in a small Ohio town, where he worked with his father in a print-shop where he self-taught himself (Shi 106). During the Civil War, Howells earned a consulship in Venice, where he began to develop an interest in contemporary affairs, and by 1871 at age 34 Howells was appointed as editor of the Atlantic Monthly. With this meteoric rise to an upper-middle class station, Howells wanted to emphasize good fiction for the mass marketplace. Howells gained significant power in his role: while the middle classes grew in 
prominence, fiction was mass-produced at a rate it never had in the past seeing as how a massive reading public had opened. With this, certain populations in the middle-class demanded a more serious type of fiction even as writing from the generation before also grew in popularity. One can infer that a demand for this medical fiction existed based on the sheer output alone. Howells collaborated with and mentored several other writers who demonstrated a commitment to representing material reality, including Phelps and Jewett, yet at the same time, one can find acceptance of the emerging new middle-class status quo in his work, especially the issue of medical professionalization in Dr. Breen's Practice.

In his role as editor, Howells demonstrated an interest in fiction that his reading public could relate to, and in doing so, Howells emphatically realized the social function that realism had. For Howells, the social function was a key element in his conception of realism's form. Unlike the Romantic fiction that celebrated creative genius of individual artists working in isolation from one another, Howells emphasized that in such an age of rapid social change, fiction needed to document the changing social times, and it needed to have use-value for its readers: "the whole field of human experience was never so nearly covered by imaginative literature in any age as in this; and American life especially is getting represented with unexampled fulness" (qtd. in Petrie 108). Literary critic Daniel Borus argued that, for Howells, literature's primary responsibility was an ethically purposeful engagement with social realities shaped by author, audience, and fictive characters, undertaken "as a form of political intervention designed to repair the fissures that had run through nearly every aspect of American life" (qtd. in Petrie 14). One does not have to go far to look for such fissures in the corpus of Howells' work: The Rise of Silas Lapham, for instance, dealt with the fissures produced by a new wealthy class emerging and their conflicts with older generations of wealthy families. As Paul Petrie notes, 
aesthetic value in realistic works remained "cognizant of the literary work's relative success in meeting that (social) responsibility; therefore, prioritizing a work's poetic symmetry or celebrating a work's language took less of a priority than its social function; in other words, Howells subsumed literature's "aesthetic value within its use-value, which thereby encompasses not only the literary artifact's idiogenetic artistic qualities but also the effects of those qualities on the actions of real readers in the world beyond the immediate act of reading" (18).

While Petrie persuasively argues the case for the use-value for readers in Howells' fiction, he underestimates the importance of the structure of his novels. It is part of the use-value of his work to heal divisions, to bring conflict to a close so that social ruptures can be healed. What is at stake then is the 'correct' perspective in which to arrange the proportions. Howells forces diverging plot conflicts together to create an ending where social fissures, in this case the danger posed to the mainline profession from a homeopathic woman, are healed for the sake of unity. The other novelists we examine adjust the proportions in their own ways in order to arrive at their vision of truth. What occurs then is that the realist form allows for all these writers to negotiate with the politics of professionalization in differing ways, but they all must deal with unity in some way: Howells endorses the status quo by healing all conflict in his medical novel, whereas these conflicts are not as neatly resolved in the other texts.

Before examining the extent to which Howells endorses the mainline profession with the way he neatly resolves the fissures created by its heroine, we should mention the complicated relationship Howells had with the medical establishment. It is difficult to ascertain Howells' beliefs about whom he thought had the best ideology; unlike a writer like Hawthorne, who was skeptical about both allopathy and alternative medicine, locating Howells' political stance is an uncertain task as he was a patient of doctors from both sects. Unlike the other literary modes, 
where a knowledge of authorial intent can be valuable in discerning the extent of the form, the realism of Howells concerns itself with documenting social problems and resolving them, often to the role of existing power establishments for the sake of narrative symmetry. The biographical evidence we do have is that Howells and his family were treated by homeopaths, but this was because his wife, Elinor, like Hawthorne with Sophia, preferred them over regulars. When one of his children grew ill, Howells, however, switched to an allopath (the oft mentioned S. Weir Mitchell) despite her protests. While this analysis argues that Howells' realistic form endorses allopathy to resolve all these power dynamics, we cannot know with absolute certainty what $\mathrm{H}$ personal feelings were on the issue.

Before jumping into how Howells' belief in literature as social fiction specifically influenced his medical novel, a discussion of how it affected his fiction in general is in order. As mentioned above, Howells deemphasized a style of literature that alienated the middle-classes, so he coined a term, literosity, to separate what he thought was a pompous literature of the cultural elite. Howells thus emphasized a common language representative of all, and this emphasis on the language of common people influenced the more regional works of writers like Phelps and Jewett. Since Howells perpetuated a form grounded in the tastes of middle-class readers, one can thus infer that his plots typically would not deconstruct the superstructures governing this emergent new class. Howells also rejected didactic qualities in his writings; this aspect of form does not arise in his medical novel, but the other women writers stress it in varying degrees for different purposes. He believed this in part due to the nature of freedom and the will versus determinism for an accurate portrayal of someone's life; David Shi notes that Howells, and by extension, the Realists believed "that characters should be capable of making genuine choices. Instead of being governed by implacable fate, people in realistic novels confront viable options 
and retain a sense of agency. Their own decisions and reactions to events give shape to their life" (119). While Howells believed this to be an aspect of realism's form, his belief that realistic characters have agency does not match with his medical novel, where his protagonist Grace doesn't exert any form of agency in her decision to leave her career.

Howells' medical novel Dr. Breen's Practice creates the template for the realistic medical novel that the later writers would work from and mold to their own ideas of reality. Fresh from medical school, the newly minted homeopathic Dr. Grace Breen vacations with her mother at a New England beach where she meets her first patient, Mrs. Maynard, after she develops pneumonia from sailing in the storm; this was an excursion Grace persuaded Mrs. Maynard to do. During these actions, the narrator informs readers that Grace underwent a heartbreak during medical school where her best friend betrayed her by coupling with Grace's fiancé; therefore, the heartbreak causes Grace's passion for her work to weaken. At the vacation spot, she befriends Mr. Libby, a well-to do industrialist and mill owner. As Mrs. Maynard grows more ill, she demands that Grace find a male doctor because she believes that women should not seek careers. Another character, Miss Gleason, champions Grace's accomplishments in becoming a female physician; however, despite Miss Gleason's encouragement, Grace cedes to Mrs. Maynard's demands and visits a local allopathic physician, Dr. Mulbridge, who because of AMA statutes, refuses to consult with Grace since she's a homeopath. Grace relinquishes her role as doctor to him and becomes his nurse. As the novel progresses, Dr. Mulbridge becomes infatuated with Grace and offers her a marriage proposal. He argues that the two can move to the West and both practice their respective types of medicine together without recourse from the state. Meanwhile, as Mrs. Maynard recovers, Grace rejects then reconsiders a marriage proposal from Mr. Libby; following the marriage, she gives up her practice of medicine but helps her 
husband's employees at the mill, where with her Puritan sense of obligation to do something and not be idle, she is satisfied. The novel ends with Miss Gleason left feeling disappointed in Grace for marrying who she believes to be an inferior man along with giving up on her calling.

Considering Howells strongly believed that realism is grounded in social occurrences, his emphasis on community building is significant to not only understanding Grace's status in society but also in evaluating the place alternative medical professionals, in this case a female one, has in the novel, and by extension, material reality. If realism is a form of expression that represents and repairs the fissures of everyday American life, as Borus argued, then one can infer that characters who defy social norms, in this case a character operating within the norms of a secluded New England resort, must have a resolution in her character arc to leave the community in a state of equilibrium by the work's end. This small-town, New England community was stratified by class and gender concerns, both of which are common themes in Howells' body of work. ${ }^{4}$ Therefore, Grace's presence and her ideologies at any given moment in the novel threaten the social order of a community so rigid that it remained divided by class.

Early in the novel, Howells spends a significant amount of time characterizing Grace along with the perceptions both Grace and locals have about her role in the community. While many of the authors of the other texts surveyed in this chapter adopted the aforementioned country doctor persona with their characters, Howells is careful to place Grace as a product of an urban environment. Early in the novel, a carriage driver is confused about Grace being a doctor, to which the narrator says:

She laughed a little to herself at the helplessness of the driver, confronted probably for the first time with a graduate of the New York homeopathic school; 
but she believed that she had reasons for taking herself seriously in every way, and she had not entered upon this career without definite purposes. (11) In the same passage, the narrator informs the readers about the heartbreak Grace endured at her ex-lover marrying her dearest girl-friend, and then goes into his perceptions about Grace's resolve: "Those who had more of her intimacy understood that she had chosen this work with the intention of giving her life to it, in the spirit in which other women enter convents, or go out to heathen lands; but probably this conception had its exaggerations" (12). Perhaps most important to the passage, the narrator mentions that Grace does not need to practice medicine to earn a livelihood: "she was rich enough to have no need of her profession as a means of support, and that its study had cost her more than the usual suffering that it brings to persons of sensitive nerves" (12).

This passage achieves a number of purposes in creating a medical novel centering on Grace's agency or lack thereof as she is subject to several social forces beyond her control; this passage also anchors the novel in its structural logic. These descriptions all convey some classbased nuances as Grace learned her profession in New York, one of the burgeoning, urban centers of knowledge for medicine; on the other, she is a homeopath, the sect that with its more patient-oriented approach normally thrived in either rural communities or in cities as personal doctors for the wealthy, and on another, her first patient, Mrs. Maynard, presumably belongs to the upper class as she vacations away from her estranged husband, and the upper-classes tended to gravitate towards homeopathy for its more patient-centered methodology. These descriptions all place Grace in an awkward position to begin the novel as she is an upper-class woman lowering herself to a middle-class profession by attending to the needs of upper-class patients. Considering the professionalization of medicine was a middle-class movement that standardized 
and unified all the new medical graduates into a social position, it is also significant that Howells characterizes Grace as not needing to practice for her well-being. The narrator questions her resolve with the line: "this conception had its exaggerations." From the onset, Grace is thus a liminal figure trapped in a variety of competing spaces. As a homeopath, mainstream allopathic medicine does not consider her a true professional, as homeopaths had fallen out of favor, but Grace also went to an institution to learn her craft. She could revert to her Old Wealth lifestyle, but she feels a compelling interest to do something else with her life, and she presumably wants this after a disappointing heartbreak. At the novel's beginning, nothing is certain about Grace's role in the community; because the novel starts with casting doubt on Grace, it follows then that the problem of her entering the profession must be resolved to achieve a formal symmetry by the work's end.

While Grace presides over Mrs. Maynard's case, she assumes a place in the community as the presiding physician with a number of responsibilities. However, as the aforementioned quote by David Borus argues, Howellsian realism intervenes to repair fissures in everyday American life. Although she asserts her authority in taking Mrs. Maynard as a patient, Grace lacks the full support of most members of the community. Mrs. Maynard, for instance, denigrates Grace for two main points. Mrs. Maynard expresses discomfort because in her view, Grace steps out of her place in the social hierarchy for being a woman taking a man's profession; this point has been covered on the feminist criticisms of the novel; Cynthia Davis, for example, remarks that because of Grace's heartbreak, "homeopathy compensates for the role love once played. The fact that it does not satisfactorily do so suggests that this bargain is inherently disproportionate, swapping as it does an 'unnatural (professional) for a 'natural' (sexual) role (109). This quote from Davis largely showcases one reason why Grace feels out of place as she 
is operating within a male-dominated profession, and her attempt to enter this profession is one of the fissures the novel attempts to solve..

Mrs. Maynard's second objection has no bearing on Grace's gendered role; her second argument, spread throughout various passages in the novel, involves her frequent jabs at Grace practicing homeopathy. As her situation worsens, she asks Grace to consult Dr. Mulbridge because she wants a doctor... a man doctor" (70). Grace refuses, seeing how she "certainly wouldn't consult with a physician whose ideas and principles I knew nothing about" (72). Mrs. Maynard then goes on to call Grace a bigot, seeing how she claims she doesn't ask for Grace to give up her principles but merely to exchange a few words with another doctor because he's allopathic (73). While Grace is already at a disadvantage as a female physician, she thus further loses her place in the community seeing as how homeopathy lacks the public confidence. Grace again must deal with a major determining force, state professionalization, affecting her agency, as we shall see when we examine the character of Dr. Mulbridge. At this point, Grace also begins to fall victim to Howells' logic of realism. Mrs. Maynard exposes Grace as an exception to the standard norms and power structures of nineteenth-century society, so as Howells strives to achieve his idea of narrative symmetry, we see the problem realism must resolve: Grace is an overreaching figure by the standards of the older generations.

Furthermore, Grace's interactions with Dr. Mulbridge, an allopath, play an integral role in having her lose the authority she exerted. Mulbridge acts as both antagonist and suitor to Grace; through his antagonism, Mulbridge exerts the authority of the allopathic medical establishment over homeopathy; however, Mulbridge realizes that he is only one person amongst a much greater social apparatus. Chapter five illustrates the power dynamics that the mainline establishment had over alternative practitioners in the latter decades of the century. After Grace 
reveals that she is a female practitioner, Mulbridge is eager to work with her, keen for the chance to work with a woman, presumably out of hope that he can woo her. However, once Grace reveals she's a homeopath, Mulbridge rejects consulting with her; even if Mrs. Maynard becomes deathly ill, Mulbridge cites "disciplinary" reasons for not helping, to which the narrator quips: "The word seemed to afford Dr. Mulbridge the degree of relief which can come only from an exactly significant and luminously exegetic word" (108). Mulbridge continues that he and Grace both "belong to two diametrically opposite schools — theories — of medicine. It would be impractible - impossible for us to consult. We could find no common ground" (108). He does recognize, however, that this matter extends beyond his own discretion: "It's quite impossible," said Dr. Mulbridge. "If I advised with you, I might be - a little while ago one of our school in Connecticut was expelled from the State Medical Association for consulting with...with his own wife, who was a physician of your school" (110).

The interaction between the two thus showcases the uneven power-dynamic that the state approved group of medical practitioners had over alternative practitioners. As allopathy unified under the banner of the American Medical Association, they developed an epistemic legitimacy with the American public, and homeopaths never could unite together quite as effectively (Whooley 95). To protect the group's future relevance, the AMA would expel any practitioner who would consult with alternative practitioners; any consultation with an alternative doctor would be a slippery slope leading to the death of the profession. Grace, already unsure of her role in the community, is thus now made into an "Other" by the logic of the professionalization of medicine, and in turn, she now has no place in her function in the community, at least so long as she refuses to cede further control to Mulbridge. With this passage, we again unravel the 
determining force of state statutes that solidified what was before in Jacksonian America more of a blurred line between the varying methodologies.

Frustrated with Mulbridge, Grace does relinquish control over the case to him; this surrender gives Mulbridge, and by extension allopathy, full authority over the case. Grace gives up her place in the community, but in doing so, she reverts to a figure who is now less of a threat at disrupting the social order. Grace says:

I have no right to endanger another's life, through any miserable pride, and I never will. Mrs. Maynard needs greater experience than mine, and she must have it. I can't justify myself in the delay and uncertainty of sending to Boston. I relinquish the case. I give it to you. And I will nurse her under your direction, obediently, conscientiously.

This passage is integral to the novel's logic concerning the role of alternative medicine in this historical era of increasing medical professionalization. Grace goes out of her way in ceding control to Mulbridge when she claims that he has a "greater experience than mine." While Mulbridge had practiced medicine longer than Grace, she nonetheless argues that Mulbridge's medicine would doubtless have a greater effect on Mrs. Maynard. Considering Mrs. Maynard exaggerates the extent of her illness, Grace's comment on a greater experience suggests that Mulbridge at least has more authority in the public confidence. At the same time, the narrator characterizes Grace as a heroine sacrificing her beliefs for the greater good. Unlike the heartless Mulbridge, she does cede power, refusing to give in to miserable "pride" for the good of the patient; however, she relinquishes the case, obediently and conscientiously, thereby creating a text that endorses the medical power structures rather than challenging them. Grace's surrender fits into Howells' ideal of realism as requiring a unifying narrative symmetry. She is a heroine in 
a Stoic sense as she resigns to all these predetermining forces outside her control. In Howellsian realism, Grace is a heroine because she cedes her place as an outsider and returns to the status quo, which in turn heals the fissures that realism represents in its attempt to apolitically represent "the real." In this way, she is similar to Silas Lapham, who returns home to his humble abode after his financial disasters, which settles the issue of class status in that novel.

With respect to the issue of marriage in defining the social form of his medical realism, this analysis agrees with other studies that argue Howells constructed his endings in an attempt to achieve formal symmetry in the novel's structure; however, we extend this analysis of symmetry to the theme of professionalization. In the chapter on her aforementioned study of realism, Amy Kaplan, writing about Howells' The Hazard of Good Fortunes, remarks that Howellsian realism is in itself "an elaborate balancing act: it reconciles social diversity within an overarching community, assimilates disparate facts to a commonsense morality, and frames a plenitude of details within a coherent form" (46). Davis further argues that to achieve this sense of coherence, Howell does not always achieve symmetry in narrative theme and socio-historical context, so he must balance this with a formal proportion to unify everything into the complete whole (106). For Davis then, closure in Howells' novels is significant in that here, "form meets history...the drive toward narrative symmetry meets a resistance to the essentialism that fixes meaning surely, solely, or finally within finite forms" (121). In other words, for Howells, forcing the text to bend to a neatly tied resolution is integral to the form, a form where we should be left to ask, "is that all?" Thus, not only is there a gendered theme at stake in this novel's resolution, but the novel also resolves the disequilibrium caused by alternative practitioners in this newly professionalized medical marketplace. For Howells, no alternatives besides allopathic 
medicine can exist in the boundaries of respectable American society; a practitioner like Grace can only exist in the liminal space of the American West.

In order to discern the implications of Grace's eventual marriage to Mr. Libby along with the cessation of her profession, we will draw a point of comparison with Dr. Mulbridge's marriage offer since both proposals have different implications for the greater community regarding medical professionalization. For Grace, Mulbridge is a bit of a double-edged sword in the sense that a marriage to him would allow her to practice homeopathy in the West where civilized society has not yet created laws on medical professionalization. On the other hand, to marry him would be a case of Grace ceding her role in elite society, and it would further signify the potential for revolutionary class upheaval since the process of professionalization is by its very nature a middle-class apparatus in protecting its interests. If she marries Mulbridge, it would signify a larger wedding between the professional and elite classes; such a marriage invalidates the very logic making up the social turn towards a professional class. The marriage would also create a tension between the country and urban doctor dynamic. While Grace's homeopathy helps her with upper class patients, Mulbridge treats the rural community; thus, Grace has no desire to be a country doctor.

The conversation between Grace and Mulbridge during the marriage proposal illustrate the implications of this marriage to Grace's gender along with her profession; in this case, both are synonymous. Mulbridge cedes the point that Grace is a competent physician, but he claims she cannot succeed as she is a woman; this is the novel's way of further amplifying the gendered determinism theme at stake. Mulbridge admires her submissiveness in ceding the case to him, a submissiveness that, while gendered, also has class implications: "Under my direction, you (Grace) have shown yourself docile, patient, intelligent beyond anything I have seen" (257). He 
continues that if she has “any scruple about giving up your (her) theory of medicine, you needn't do it; and the State Medical Association may go to the devil" (258). Mulbridge places Grace in a subservient, nurse role as she helped him treat Mrs. Maynard, and he revels in how "docile" she is to also commemorate the victory of professionalization along with his presumed conquest over the opposite sex. With this victory, Mulbridge thinks that the logic of professionalization has already been met; therefore, he no longer would need a certification from the AMA to practice as he has already demonstrated the victory of his profession in the epistemic contest between allopathy and homeopathy, a victory that has larger class implications in that the emergent middle-class allopaths triumphed over the upper-class homeopaths. As aforementioned, Grace is also unsure about her passion for continuing the profession anyway, so this arrangement would not resolve this problem with respect to the inevitable conclusion to the marriage plotline. Such a complicated dynamic would thus interrupt the sense of harmony and symmetry that the neatly wrapped Howells novel offers.

Howells pairs Grace with Mr. Libby to meet the conventional ending that resolves the tension of both having a female as well as a homeopathic doctor practicing in the community. The marriage also fixes the class dynamic as Grace leaves the medical profession to marry Libby, a textile mill owner who inherited his prosperous business from his father, thus pairing two figures of old wealth together. In turn, this marriage leaves the Progressive move towards professionalization untouched; by the novel's end, no one breaks the standards created by the AMA, and a harmonious ending ensues where no one is wronged. Grace travels to Europe with Libby, where even upon returning to America she adopts a high-class lifestyle in spending weeks at a time in Boston during opera season. While not practicing medicine, Grace helps to treat the mill workers' sick children (302). In this manner, Grace finds an outlet for her disposition to 
help other people while also dropping the profession that she lost interest in during her previous traumatic heartbreak. All the plot threads are resolved; that, for Howells, was the point of the realistic novel in its documentation of social problems rather than taking a didactic stance for one of the positions.

While Howells is reticent to directly intervene in the novel's formal balance, he does leave the revolutionary potential open for a middle-class system not dominated by men in the figure of Miss Gleason, a figure whom he characterizes as being a lone voice in the wilderness who didactically emphasizes the effects Grace potentially could have. Early in the novel, the narrator mentions that Miss Gleason is a heroine worshipper who admires Grace for the potential example she could set for other women. Before Grace consults Dr. Mulbridge, she also expounds on the implications of a potential surrender to him: "If you yield, you make it harder for other women to help themselves hereafter, and you confirm such people as these in their distrust of female physicians” (86). After Grace marries Mr. Libby, Miss Gleason leaves the novel disappointed; the narrator notes that Gleason felt grieved at "the waste of those noble aims with which her worshipping fancy had endowed the girl (Grace) even more richly than her own ambition" (299). Gleason refuses to believe someone as talented could "be in love with a man so much her inferior: the conception disgraced not only her idol, but cast shame upon all other women, whose course in such matters is notoriously governed by motives of the highest sagacity and judgment" (300). Howells characterizes Miss Gleason in these passages as being overbearing person, a hero worshipper who lacks the pragmatic ability to navigate the world of experience. However, despite the narrator's choices of words about Gleason’s “worshipping fancy," Gleason's advice to Grace about surrendering to Mulbridge proved to be true, both for the advancement of women and for the continuation of democratic medicine. Gleason may feel 
excluded in the novel's conclusion, but she stoically persists in her cause in chastising professionalization's overly patriarchal logic. Perhaps, Gleason might find a new protégé to advance her cause. Howellsian realism may not directly intervene and argue for an ideology in its emphasis on formal balance, but the form still leaves room for Gleason, a Shakespearean fool of sorts who is acutely aware of larger social forces at stake, a character who says exactly what some readers, and likely some of the following authors, thought about the novel's resolution.

\section{V: Phelps' Engagement with the Politics of Professionalization in Dr. Zay}

When it comes to her medical novel Dr. Zay, Elizabeth Stuart Phelps has long been compared with Howells because of the similar narrative arcs between the stories. Phelps's novel has parallel formal elements Howells established in Dr. Breen's Practice, published a year earlier. Whether it was by accident or not, Phelps shares the same interests in various types of social determinism affecting her doctor, Dr. Z.A Lloyd. The novel aims not to extend its reach beyond the realm of possibility, and like Howells, the work strives to aim for formal symmetry as Dr. Zay decides to marry her suitor, Mr. Yorke, where in turn she likely cedes her place in the profession. While Phelps gives readers the same façade as Howellsian realism in unifying the plot threads in an attempt at formal symmetry, Phelps inverts the marriage plotline to showcase that while she agrees to marry Yorke, it will not end well. The disequilibrium produced by this effect, in combination with the narrator's constant praise for Zay throughout the novel, causes disharmony. In this way, Phelps creates a reductio ad absurdum out of the formal determinism binding Grace in Howells' novel, which in turn leaves the novel in a state of absurd equilibrium. The entire novel argues that Zay belongs to her profession, and if anything, Yorke's intrusion into her rural Maine community is obtrusive. If that threat is removed, life, with Dr. Zay as the 
physician, would carry on as normal in this ideal setting; however, the novel leaves the rural community in a state of chaos.

While Phelps and Howells had a close working relationship, as Howells was a patron of her work, the two had differing beliefs on the social function of literature and the realist aesthetic. Since both writers composed their works at roughly the same time, Howells went to great distance to find out that he was not plagiarizing Phelps. We can ascertain that they were two people who came to similar ideas; Howells took his completed manuscript to Phelps to ensure that no discrepancies existed, but Phelps refused to read his text at that time. Although he sought to distance his novel from hers, he nonetheless used his power as editor to publish the novel through The Atlantic (Davis 113). In her Chapters from a Life, Phelps differs from Howells in that a realistic portrait of life requires moral imperatives: "moral character is to human life what air is to the natural world;--it is elemental." She continues by noting that one cannot accurately portray real life without some examination of morality: "The last thirty years in America have pulsated with moral struggle...It has ranged from social experiment to religious cataclysm, and to national upheaval...even moral reforms, even civic renovations, might have their proper position in the artistic representation of a given age or stage of life" (qtd. in Sartisky 284). Perhaps in part because of this emphasis on moral imperatives and even didacticism, Phelps lost her place in the literary canon until the revival from feminist critics that brought many other nineteenth-century authors to the canon, and from an aesthetic judgment, many early literary critics dismissed the corpus of her work as romantic religious novels (284). As we thus see, each author's individual perspectives on issues like didacticism add to their own spin on how to negotiate both social and narrative determinism arising in the mode. 
The novel's plot centers on Mr. Waldo Yorke visiting the rural Maine countryside for both business, as he sets out to inherit his deceased uncle's property, and for pleasure as well. With regards to professionalization, Yorke, a lawyer, is himself a member of the former gentry class who, with the rise of industrial capitalists, kept their prestige if not their money. As a member of the leisurely gentry, Yorke showcases that class's newfound entanglement with middle-class professional interests; as aforementioned, Howells also investigated this theme in Silas Lapham. Upon arriving there, Yorke has an unfortunate accident causing him to become bedridden where he then becomes the patient of Dr. Zay. The remaining text is an extended argument from Yorke to Zay to give up her practice to return to Boston with him in marriage, to which Zay resiliently stands her ground. She cites professional ethics between doctor and patient considering homeopathy's close association with the patient. Like with the way doctors treated women patients, Zay blames his hysteria for this desire to be with her. As the novel progresses, Zay grows ill after treating a number of patients during a flu outbreak, and even when she gets better, her body never recovers the same strength it did, and her spirit does not either. Zay rejects Yorke a final time, and Yorke returns to Boston, but months later, he surprises her and again resumes his attempts to woo her. At novel's end, Zay agrees to marry him.

Phelps, through her treatment of nature in the novel, sets in motion the deterministic narrative where the young female doctor finds herself at odds with various deterministic mechanisms. The early pages in the novel characterize the rural, Maine countryside as a sort of pastoral ideal, a locus amoenus that, like a Shakespearean comedy such as A Midsummer Night's Dream or As You Like It, is a magical place that is immune to larger social forces from outside it. In the Maine woods, Dr. Zay treats her patients, the patients idealize her, and life continues without any outside forces, like state statutes regarding medicine, interfering with it. Waldo 
Yorke then enters the scene and darkens this ideal setting, bringing with him a web of deterministic chains: state control over medicine, the marriage market, and even the logic of Howellsian realistic form.

The first chapter alone provides two passages that illustrate the pervasive forces Yorke carries with him to the rural area. In the opening pages of the novel, Yorke travels through the countryside, and the narrator describes a traditional "garden" setting in American literature:

The route that young Yorke had chosen led him into the unparalleled deserts and glories of the wild Maine coast. Sudden reserves and allurements of horizon succeeded each other. They were finely-contrasted, like the moods of a woman as strong as she is sweet, and as sincere as she is either...At the turning of a rein he plunged into an impenetrable green solitude. He became, perforce, a worshipper in Nature's cathedrals... (9)

This traditional passage describing the beauty of American nature has of course precedent with the New England transcendentalists; Yorke's first name is "Waldo," a likely referencing Emerson, and these sorts of passages extend back as far as Columbus's letters to Spain. In a book that is centered on social and gendered politics, it is significant that Phelps spends so much time in the novel's beginning showcasing the landscape with which Yorke, an intrusive Boston lawyer, finds himself immersed.

In contrast, just before Yorke finds the town of Sherman, Maine in that same first chapter, Phelps's narrator, in describing Yorke's point of view over the entire scene, describes the opposite traditional description of nature in American literature: the uncultivated, untamed, 
harsh wilderness:

The shadow deadened as they rode, but not from the darkening of the day...Vistas of soft gloom stretched on. There was no light now, but flickering needles, fine as those of the pines, and drifting with them, that with difficulty pierced the opaque green heavens of the overreaching trees. One looked twice in the low tone of the place even to see what the roadside flowers were. Yorke had almost passed unnoticed an apple-tree in full blossom, and it was past the first of June. Nothing could have so vividly presented to him a sense of the painful Maine spring, and the frozen, haggard life that looked out from behind it upon a gentler world. (22)

Considering the texts present differing descriptions in the same chapter as Yorke journeys to the town, one can infer that Yorke has something to do with this. If one was to look across the whole novel, Phelps spends little other time offering descriptions of the scenery. Like in a Shakespearean comedy, where characters intrude into the forests thus bringing into the area all their concerns, Yorke carries with him to Sherman all the problems of the nation, and the forest through which he travels shields its rural inhabitants from all these varying social concerns.

Once Yorke is injured, the novel instigates a lengthy character study of Dr. Zay. Phelps characterizes her as a strong, able-bodied woman who, despite being a homeopath, is a skilled professional. Despite being a character in a "realist" novel, Zay is portrayed in a hyperbolic way as the ultimate Platonic form of a person destined to be a healer:

She was the eidolon of glorious health... She seemed to radiate health, as if she had too much for her own use, and to spare for half the pining world. She had the mysterious odic force of the healer, which is above science, and beyond 
experience, and behind theory, and which we call magnetism or vitality, tact or inspiration... (98)

This description of Zay insinuates that she is the ultimate healer, a woman who through the sheer strength of her spirit exudes such vitality that she is "beyond experience" and thus not subject to the "real" world. In such a world, it does not matter whether Zay is a homeopath or an allopath; what matters is that she has such a strength of will to heal; no one can topple her at her art. Considering this takes place in a realist novel, where everything is subject to determining, even textual forces, Zay appears immune to anything that would stand in the way of practicing her craft, especially a suitor who will ask her to give up her vocation. This description also showcases homeopathy's description of the vital force that, once corrupted, is what causes patients to lose their health. Zay thus exudes vitality, a nearly flawless vital force that has not yet been corrupted by bodily ills or even social and narrative determinism.

In creating such an ideal character, Phelps does not leave Zay's homeopathic practices unexamined. By the time professionalization is discussed in the novel, Yorke and Zay have had multiple interactions; Yorke is healing rapidly, and it happens as his infatuation with Zay intensifies. Yorke, fascinated by the idea that Zay could be both a doctor and a woman, asks her where she learned her craft, to which Zay responds "New York, Zurich, and Vienna." Yorke then asks why she practices in the rural countryside, to which she replies that "There is refinement and suffering and waste of delicate life enough in these desolate places to fill a circle in the Inferno"; she learned this from experience in Sherman where her predecessor, a woman from Boston, helped her mother on a vacation there as a child. Despite Zay's magical presence in the locus amoenus, she does have professional expertise as well as an international background in learning from the best theorists in Switzerland and Vienna. What is significant to 
the novel's structure is that in Sherman, Zay is the ultimate authority on medicine; no one questions her expertise. Yorke's very act of asking for her qualifications is the moment that disequilibrium sets in with the mechanism of the realist novel's plot. Zay's practicing medicine because of a trauma from her childhood, combined with Yorke's assumptions on gender politics, thus sets in motion this plot thread extending over the rest of the novel. However, even with this realization, Phelps also starts her argument that extends over the rest of the novel: Zay is a true professional. Like many allopathic regulars, she traveled overseas for her medical education. Her act of treating to the needs of a small town for a meager salary when she has greater earning potential elsewhere is also a heroic act. As a homeopath, instead of being in a laboratory, Zay attends to the needs of her patients. Even as Yorke brings outside forces into the town, attempting to remedy the disequilibrium he senses, Zay feels secure and happy in her role.

The narrator discusses homeopathy from the skeptical Yorke's point of view to showcase his denigration of Zay's abilities: "He amused himself with her fervor, while revering her skill. When she alluded to the Divine Truth in connection with her sugar-plums, he laughed"; however, after their carriage passes by a place where Zay treated a patient, Yorke experienced "at moments a species of awe of this studious and instructed lady" and appreciates the fact that she could be a physician despite larger social circumstances (136). With this moment, alongside the Maine woods going from a paradise to a wilderness, we again see professionalization arise as a determining factor. Yorke is amazed not only at the fact that Zay accomplishes so much as a woman physician but also the fact that she is so studious and so instructed, despite larger social circumstances, circumstances that include her not belonging to mainstream medicine. This passage again illustrates homeopathy's contribution in adding to the lack of equilibrium in the community. Despite no one caring before Yorke gets there, his very presence instigates the 
otherness present not only in Zay entering a masculine profession but also in practicing alternative medicine.

Although Yorke's skepticism acts as a plot device of sorts to instigate the Howellsian novel's emphasis on narrative symmetry, the remaining novel functionally serves as an essay on Zay's ability to function both as a female professional and as a homeopath. The novel itself, through Zay's persuasive speeches, overwhelms the reader with the fact that little to nothing is wrong with her practicing as she is skilled at her profession, her calling. It also engages with the idea that a woman professional in a sect as involved with treating patients as homeopathy would likely require a change in gender roles since she cannot both take care of her patients and Yorke, and by extension the traditional conservative literary mode of Realism, balks at this idea. Despite the narrative arguing that nothing is wrong with Zay practicing, it does insinuate that she cannot both practice medicine and take care of Yorke as a traditional wife. In engaging with Howellsian literary realism, Phelps thus showcases the revolutionary potential of such a scenario, and she argues it so persuasively that the novel's ending thus feels disingenuous.

These conversations happen about midway through the novel as Phelps characterizes Yorke as a man of the past and Zay as the professional woman of the future; in a dialectical sense, they are a thesis and an antithesis that cannot produce a synthesis. This conversation further amplifies Zay's mystique and otherness just before Yorke wants to formally engage with her in a romantic relationship. After witnessing Zay's failed attempt to save an infant from the scarlet fever, Yorke, through the omniscient narrator's descriptions, thinks through the implications of both gender roles and professionalization: 
She had her dangerous and sacred feminine nerve under magnificent training. It was her servant, not her tyrant; her wealth, not her poverty; the source of her power, not the exponent of her weakness. She moved on her straight and narrow way between life and death, where one hysteric moment would be fatal, with a glorious poise. The young man acknowledged from the bottom of his heart that she was a balanced and beautiful creature. He had read of such women. He had never seen one. (111)

Yorke sees Zay as a sort of exotic animal to be tamed, a challenge to be conquered. Never had he seen before a woman who could both exude femininity and professional training. The narrator describes her as a "creature" beautiful in large part because of this balance. This motif goes back to Petrarch's "Rime 190" as well as Sir Thomas Wyatt's poem "Whoso List to Hunt"; this conceit of course is that chasing an unapproachable woman is like restraining oneself in a hunt where the most beautiful animal is off limits. While Petrarch and Wyatt both had their individual reasons for their poems, Phelps's narrative features an exotic woman who is so precisely because of her professionalization, and the narrative energy, unlike those poems, thinks through the implications of Yorke taming the subject.

Within the same conversation, Zay starts a more pragmatic dialogue outlining the balance she constantly navigates between professional duty and personal relationships:

There are new questions constantly arising for a woman in my position. One ceases to be an individual...I suppose everything in this world renders its cost, but nothing so heavily, nothing so relentlessly, as an unusual purpose in a woman. 
Nothing is more expensive than sustained usefulness,--or what one tries to make such. I hate to think of petty things! (128)

This delicate balancing act extends throughout the novel's duration as she deals with Yorke's advancements despite her professional ethics in having him as a patient. Late in the novel, Yorke's infatuation causes him to profess love for Zay. Not being able to take no for an answer, he asks if she's a woman, to which she responds: "I am a doctor" (193). Zay continues to reject him because of her ethics, and the narrator notes that she urged this point "with decision, but not without tenderness, --that ready, cruel, professional tenderness; he would rather she had poisoned him" (194). Zay then, with deadly irony, diagnoses Yorke with hysteria, and she also remarks that her sect's close bond with the patient likely caused this symptom: "You do not love me. You have needed me. I have been useful to you. I have occupied your thoughts. You may miss me. But that is not love. Go home, and find it out. Get well, and find it out" (213). All these passages added together make an argument not only for Zay's complete sense of professional ethics but also the fact that she does indeed belong in the community as she balances all the competing expectations placed on her. However, at the same time, all these passages also argue that her professional duty is not compatible with traditional domestic duties, but that isn't necessarily a bad thing, especially if marriage entails wedding such a needy man as Yorke. While Yorke's presence in the novel thus creates a sense of narrative determinism for resolving the thematic problem of professionalization, the narrative energy resists the inevitability of this determinism, which in turn highlights the absurdity of the mode's formulaic disposition.

The novel works toward the realist problem of resolving every plot thread and restoring harmony to the community; however, even as it does so, it continues to resist the idea that a marriage between Zay and Yorke will work. In what appears to be a war of attrition, Zay finally 
professes love for Yorke. Even in doing so, she admits in a lengthy passage that she has a Platonic ideal as to what makes the ideal marriage, an ideal only a few people she knew grew to achieve: "I will not stoop to anything I can fathom and measure. Love should be like a mighty sea. It should overflow everything. Nothing should be able to stand before it. Love is a miracle. All laws yield to it. All laws yield to it" (212). She also notes that in her role as local doctor, she saw the discontent and the unhappiness that arises in such situations, and when Yorke replies that they love one another, she remarks, "We think so...You think so. But you do not know what it all means" (213). It is not a stretch to say that these passages cast doubt on whether this marriage will succeed; while Howells left Grace's happiness ambiguous, Phelps argues that such a pairing is disharmonious and contrary to nature. It would not even work as far as her vocation goes considering Yorke constantly resists the idea of the new, professional woman. Even as the novel works toward an ending, Phelps thus only creates an even greater lack of equilibrium than when the novel starts.

The novel's conventional romantic ending features Yorke coming to a tenuous acceptance of Zay's medical career, and through the function of realism, they are likely to be married. Most critics agree with this assessment in that the novel's conventional romantic ending seems awry, though none of the others have focused as much on the role of medical professionalization to the novel's determinist web as this analysis. Cynthia Davis notes that Zay's wooing "seems more a function of Phelps's authorial duties - her ultimate obeisance to the conventions of literary form - and her dialogue with both (Dr. Edmund) Clarke and Howells" (116). She also argues that “Zay's consent may not, after all, shore up compensatory theories of organic forms but instead serve to critique them, given that such a conclusion is represented as less than happy and far from equilibrious" (119). Michael Sartisky also claims that "on the 
surface the novel offers the superficial explanation that Yorke has reconciled himself to her career, but this is emphatically outweighed by his characterization and Phelps's reluctance to extend the plot to see if this ideal relationship can be realized" (294). Both Davis and Sartisky expertly note that no equilibrium exists even as the novel feigns to have it; however, both do not discuss the implications for the professional class and the local community. Without Zay, Sherman, Maine will be thrown into a state of chaos; the Eden free from governmental intervention has now been invaded. Many of Zay's patients will no longer have a doctor, and Zay's wedding to a lazy aristocrat inverts the constant feeling she must do good. In this manner, Phelps adjusts the proportions of her ending to account for realistic forces pressuring Zay. Because the romance at the end is so forced, the novel lacks a sense of unity in the same way that Howells' novel managed it, and that is precisely the point; Phelps' novel suggests that a 'real' text from her point of view lacks the same sort of neat resolution of Howells' text.

\section{VI: Jewett's Resistance of Professional Politics in A Country Doctor}

Of all the writers surveyed in this chapter, Jewett is the most notable in developing a counter-realism to Howells with regards to the idea of women entering the profession and assimilating themselves into the new social order. Jewett notably disagreed with Howells on the issue of didacticism. David Shi notes that although she was determined "to avoid being 'preachy' and quite conscious of the danger of letting sentiment fall into sentimentality, Jewett believed that fiction should include moral messages in the form of 'silent scripture' (115). Even though her fiction was laced with a political subtext, Jewett was praised by Howells since unlike something like an antebellum reform text, her work managed to avoid an excess amount of melodrama and emotion (119). Jewett's novel A Country Doctor borrows similar formal structures as the other writers surveyed here: her protagonist, Nan, is a homeopath, the novel 
emphasizes the theme of community building and the young doctor's role in trying to navigate between rural and urban life, and Nan must choose whether to marry.

With regards to plot, Jewett disavows the attempt at formal symmetry that Howells, and even Phelps, aspired to in some way by forcing a traditional ending of a marriage or engagement. At the same time, Jewett manages to achieve a symmetry of her own by structuring her novel as a bildungsroman; unlike the other novels, A Country Doctor advocates for its protagonist by showcasing her desire to practice medicine from an early age, along with illustrating that practicing medicine is a calling, a dictum issued by God not to be ignored. Nan also has a support network in her mentor Dr. Leslie, who advocates for her entering the profession. Furthermore, through the bildungsroman, Jewett anchors her character in more of a genetic rather than social determinism: Nan's father, a member of the New England gentry, rejected that life to be a doctor, and his wife was a free spirit who belonged neither in a rural or urban environment. These biological tendencies pave the way for Nan to be a pioneer in her profession as she borrows from both of her parents to reject a leisurely gentry lifestyle for her profession and her patients.

The novel has a critical history that is grounded in Feminist and New Historicist criticism. Like other realist writers, Jewett's work found a new audience in the late 1970s and 1980s with the rise of the aforementioned literary criticisms. Of Jewett's work, the novel has not been studied as much as "A White Heron" or The Country of the Pointed Firs; however, it has a body of criticism. Biographical criticism on Jewett reads the novel from her experiences; her father was a practitioner in Maine, one of the first states to allow women into the profession; furthermore, Jewett's personal relationship with Annie Fields has been discussed seeing how Fields was a strong advocate for female doctors. ${ }^{5}$ Because of Jewett's relationship with Fields, 
the novel has also been read through the lens of gender and Queer studies, seeing how Nan rejects her marriage and shows little interest for her suitor in the novel. The most recent strand involves reading the novel through the lens of a country and urban dichotomy both in terms of the national scale and in terms of the medical establishment. ${ }^{6}$

Characters in both Howells and Phelps struggled with formal determinism - the text's structure demanded a certain resolution — alongside a social determinism — the profession could not endure based on both the gender and the type of medicine Grace and Zay practiced because of the norms involving both issues. If Jewett was to write a realist project rebelling against both these types of determinism, then one might infer that her heroine would exercise free will in determining her own path based on her talents. In her attempt to deliver 'silent scripture' in offering a path to the profession for women, Jewett instead enacts a determinism of her own in suggesting that God has predestined Nan for her path; furthermore, God creates everyone for a purpose, and Nan's purpose centers around her innate talents as a healer, talents she has had since childhood. In this way, while the function of her realism changes, i.e., Nan leaves the novel satisfied with her profession and her role in the professional class rather than ceding this through marriage, the form remains the same in that realism is still anchored within a determinist framework along with a sense of harmony and symmetry happening; since God determines Nan's path, anything other than her success as a doctor would not work. Thus, Jewett manages to create her form of counter-realism by interjecting a determinism that governs all others.

Jewett's novel is a bildungsroman that begins with Nan's mother, in a last effort of desperation before her death, delivering Nan to her grandmother in a small town. As the years progress, Nan's grandmother finds that she cannot control Nan's free spirit, and upon her death, Nan goes to live with Dr. Leslie, the local country doctor. Dr. Leslie allows Nan to cultivate her 
own interests while he is a distant mentor, and from an early age, she grows an inclination towards medicine and learns from him as an apprentice. The novel's second half features Nan, now a young woman, as she enters medical school (a homeopathic one) in Boston. She meets her father's sister, Miss Anna Prince, who introduces Nan to an old wealth lifestyle. She also introduces Nan to George Gerry, and here, the marriage plotline involving female practitioners begins. The novel ends with Nan rejecting Gerry and the old wealth lifestyle such a marriage would provide, opting instead to practice medicine, the path through life that God decreed for her, along with entering the new professional class in doing so.

One way that Jewett establishes a sense of Christian predestination for Nan's professional destiny is to showcase how Nan is a tabula rasa because she grows up as an orphan and is then free to develop her own interests. This sense of being a wild flower free to grow is ascribed to Nan's mother by her father's relatives angry about their elopement; however, Nan's freedom from class structures allows her to pursue her interests early with the help of Dr. Leslie, who allows her the freedom to grow intellectually. Early in the novel, local gossip Mrs. Meeker informs Dr. Leslie that Nan belongs “with wild creatur's, I do believe, --just the same natur' (73). However, Meeker tells Leslie that she witnessed a young turkey that "had come hoppin' and quawkin' round the doorsteps with its leg broke, and she'd caught it and fixed it off with a splint before you could say Jack Robi'son. She told how it was the way you'd done to Jim Finch that fell from the hay-rigging and broke his arm over to Jake an' Martin's, haying time" (74). As the chapter concludes, Jewett's narrator describes Dr. Leslie's maid, Marilla, and her observations about Nan:

The child was strangely dear and companionable in spite of her frequent naughtiness. It seemed too, as if she could do whatever she undertook, and as if 
she had a power which made her able to use and unite the best traits of her ancestors, the strong capabilities which had been illy balanced or allowed to run to waste in others. It might be said that the materials for a fine specimen of humanity accumulate through several generations, until a child appears who is the heir of all the family wit and attractiveness and common sense, just as one person may inherit the worldly wealth of his ancestry. (Ch. 6, 73).

This passage demonstrates a few layers: the narrator insinuates that a biological determinism of sorts exists based on good qualities from good generations eventually manifesting in the right person. However, taken with the other passages here, one can also infer that being allowed to be a blank slate free from cultural interference allows Nan to cultivate rather than suppress her most notable God-given qualities, attributes that Jewett develops further as the novel progresses.

Chapter nine is a central one to the novel in many ways: it is literally the center of the book, and it unites the novel's themes to carry it through the culmination of Nan's education. Dr. Leslie is visited by his friend, Dr. Ferris, whose career has been spent as an allopath in an urban environment. One theme they discuss is Nan's propensity towards medicine, a talent given to her by Nature. The two men discuss Nan's mother, whose free spirit, combined with her lack of moral development, caused her downfall into depravity; however, Dr. Leslie's guidance has allowed Nan to fully grow, like a plant, and cultivate her hereditary predisposition toward medicine; he describes her attributes as "an amusing trace of the provincial self-reliance and selfrespect and farmer-like dignity, added to a quick instinct, and tact and ready courtesy" (119). While Nan is a child of the soil, she could also put a city household to shame. Furthermore, Leslie notes that Nan "has grown up as naturally as a plant grows, not having been clipped back or forced in any unnatural direction" (119-20). When Ferris acts skeptical, Leslie notes that 
Nan's interest in medical matters appears unconscious, but one day as he found her reading, he found her reading Dr. Benjamin Rush's tracts on fevers like a story-book (123). From all of this, Leslie resolves that if he can "help one good child to work with nature and not against it, and to follow the lines marked out for her, and she turns out useful and intelligent...I shall be more than glad. I don't care whether it's a man's work or a woman's work; if it is hers I'm going to help her the very best way I can" (124-25). This conversation performs a central role to Jewett's realist project in showcasing that Nan's God-given qualities, combined with her moral development in Christianity, are the key to her future, and Leslie argues that no cultural gender role should block Nan's calling. It contrasts with both Howells and Phelps's text, where a sense of cultural determinism prevents either Grace or Zay from continuing their careers.

The two men also converse about the merits of the changing medical landscape as the professionalization of medicine has centered in urban environments. If Dr. Leslie is a stand-in for Jewett's father, as biographical criticism of the novel reveals, then one can infer that Jewett advocates for a more patient-centered, homeopathic approach. However, the two doctors come to a consensus that a combination of new scientific progress combined with a patient-centered methodology provides the best pathway to good practice, and Nan has an advantage because she exists in both worlds. Dr. Ferris concedes many points here to Dr. Leslie; an urban doctor may have the skills of the laboratory, but he notes that he has no right to call himself a doctor unless he possesses the instinct of making everything bend to his will of bettering patients. Ferris argues that while the "anatomists and pathologists have their place," the "men "who make it their business to write the books and the men who make it their business to follow them aren't the ones for successful practice" (128). Leslie appreciates the sentiment and then provides an argument for new methods combined with an attention to the patient's vital force: 
They go on, poor fellows, studying the symptoms and never taking it in that the life power is at fault. I see more and more plainly that we ought to strengthen and balance the whole system, and aid nature to make the sick man well again. It is nature that does it after all, and diseases are oftener effects of illnesses than causes. But the young practitioners must follow the text-books a while until they have had enough experience to open their eyes to observe and have learned to think for themselves. I don't know which is worse; too much routine or no study at all. (128)

To conclude his argument, Leslie notes that we (doctors) must not "let ourselves forget to educate our faith and our spiritual intellects, and lose sight of our relation and dependence upon the highest informing strength...we worship our tools and beg success of them instead of remembering that we are all apprentices to the great master of our own and every man's craft" (130).

These passages are key to the novel's form; here, we see homeopathy's emphasis on a patient's vital force combined with an appeal to God and Nature to anchor an argument for the future of medical practice. Lost in allopathy's newfound emphasis on the laboratory is the patient, and the future of cultivating both the spiritual and physical well-being of the nation's citizens is a doctor like Nan, who, with her innate talent given by Nature to be a healer, along with her study and discipline for the practice, will lead medicine into a better future. A methodology centering only on the body lacks the care needed for the spirit; without both, the medical profession cannot hope to care for the patient. 
In appealing to the determinism of Nature, Jewett's novel manages to create a counterrealism in opposition to that created by Howells since an appeal to a divine plan overrides any sort of cultural precedent. The novel's entire second half focuses on the marriage plotline where Nan has a chance to return to the upper classes with the marriage to George Gerry. Like with the other novels, the conflict arises as to whether Nan can be a wife in the domestic sphere as well as practice medicine simultaneously. Several passages anchor the novel regarding this idea: the sheer number of them support Jewett's assertions of her novels being a means of asserting 'silent scripture.' Dr. Leslie tells her that medicine “is more than proper for you, and God has given you a fitness for it which it is a shame to waste" (Ch. 12, 209). Upon arriving at medical school, Nan realizes that a physician must be fitted by nature "with a power of insight, a gift for his business, for knowing what is the right thing to do, and the right time and way to do it; must have this God-given power in his own nature of using and discovering the resources of medicine without constant reliance upon the books or the fashion" (Ch. 13, 214). The novel's climax happens when, after reflecting upon the pros and cons of marriage, Nan arrives at an apotheosis:

She had long ago made up her mind that she must not marry. She might be happy, it was true, and make other people so, but her duty was not this, and a certainty that satisfaction and the blessing of God would not follow her into these reverenced and honored limits came to her distinctly. One by one the reasons for keeping on her chosen course grew more unanswerable than ever. She had no thought she should be called to resist this temptation, but since it had come, she was glad she was strong enough to meet it. It would be no real love for another person, and no justice to herself, to give up her work, even though holding it fast 
would bring weariness and pain and reproach, and the loss of many things that other women held dearest and best. (Ch 19, 367)

Jewett provides the reader with more passages than even the ones quoted here; these all suggest that no sort of determining factor can override the decree of God. Earlier in the novel, Jewett appealed to the idea of Nature, but now, Nan arrives at the certainty that this is her duty to do, and she in turn would not be blessed if she gave up her duty to marry.

To conclude the discussion, it must be again noted that Nan's divine calling is combined with her homeopathic training in attending to both the physical and spiritual elements of the patient. While allopathy become the national standard, late $19^{\text {th }}$-century homeopaths also went through an accreditation process. For Jewett, a medical professional extends beyond the definitions of state statutes, but if one has a divine calling to medicine, then a diploma is but one barrier. The narrator notes that sometimes Nan resented "the prospect of the many weeks which she must spend listening to inferior instruction before gaining a diploma, which was only a formal seal of disapproval in most persons' eyes"; however, she nonetheless earned the diploma as she remembered her larger purpose. This larger purpose is thus the key toward escaping Howells' cultural determinism that grounds his framework.

\section{VII: Concluding Thoughts: Helen Brent, M.D: The Problems of Free Will \& Realism}

Annie Meyer's understudied 1892 novel Helen Brent, M.D provides a sharp point of contrast with the other three novels in this chapter that engaged with Howellsian ideas of realism, most notably the idea of unity in them. ${ }^{7}$ This novel is an interesting point of contrast in that it lacks the same features of form as the other three: it is very didactic and unsubtle about its engagement with gender politics. The plot features this time a competent allopath, Helen, who 
early in life turns down a marriage proposition to attend to her career, where she becomes successful and eventually becomes president of a medical college for women. Unlike the other women in those other novels, Meyer's book suggests that Helen possessed the freedom of the will to make her own decisions; furthermore, Meyer emphatically resists the politics of realism's form in its didactic message in calling for social change. To conclude this chapter, let us then look at a novel that, despite similar plot conventions, frees its protagonist from the webs of formal, cultural, and even divine determinisms evident in the others; however, in doing so, the book also loses the aesthetical complexities associated with the realist form.

Meyer was paradoxically both a feminist and an anti-feminist, a contradiction that plays a role in how her novel approaches the issue of medical professionalization. She helped to found $\backslash$ Barnard College since she had to self-educate herself at a young age following her father's business failures. She passed examinations at Columbia that allowed for women to earn a degree; however, women there could not attend lectures to learn the material. Meyer conflicted with her father over her education, as he insisted that "she would never be married, because men hated intelligent wives" (Gordon 509). She proved him wrong, however, with her marriage to an older German-born physician, Dr. Alfred Meyer, an allopath. Her marriage allowed her the free leisure time to allow her to take up writing as a profession, as she wrote both fiction and argumentative essays in various newspapers and journals. As the years passed following her publication of Helen Brent, M.D, Meyer's views appeared to harden as she preached antisuffrage views that married women must be fully invested in their domestic duties. Historian Lynn Gordon notes that one can only speculate on the possible causes for Meyer's change in attitudes. Gordon notes that Meyer may have felt dissatisfaction at the change in feminist ideology from gender equality to the notion of women's morally superior status, a philosophy 
Meyer coined as 'spreadhenism.' Another explanation for this involved family rivalries, as Annie arguably took up anti-suffrage to spite her older sister, suffragist Maud Nathan (512). Maud took up several roles, including being president of the Consumers League, an organization "dedicated to improving working conditions for working women, and a member of the board of directors of Katherine Mackay's Equal Franchise Society" (Neuman 120). Whatever the case may be, Meyer's novel is a product of both these impulses.

Meyer's text emphatically asserts the freedom of will her heroine, Dr. Helen Brent, exerts in her choice to reject traditional gender roles by belonging to a profession. Unlike the Howellsian brand, which sought to represent the real without politicizing a cause, Meyer's text is overtly political. Although the direct influence of Howells to Meyer has not yet been documented, one can infer that Meyer was familiar with the other texts considering their similar plots; however, Meyer uses the opportunity to create something else entirely. She uses an obtrusive narrator to deconstruct the webs of causality that bind characters in the Howellsian model. Meyer also leaves her novel in a state of ambiguity as Helen regrets not marrying Harold, the man who wanted her to leave the profession to be a housewife; however, we learn that Helen accepts the choices she made in her life. To achieve free will and resist determinism, Helen must accept the implications of her choices rather than resigning herself to fate.

Throughout the novel, Meyer paints Helen as the most competent of allopathic physicians, a trait differing from the other novelists who characterized their female doctors as homeopaths. She even becomes the president of a new medical college chartered for the advancement of women. Meyer also characterizes her as a beautiful woman; she's a blonde, "very handsome, amiable woman, surely not past thirty, and very tastefully and quietly dressed" (16). However, much of the plot centers on the romantic entanglements of various members of 
the community, including Helen. Early in the novel, we learn that Helen was once engaged to Mr. Harold Skidmore, a politician. Like in the plot of Dr. Zay, Harold debates the intricacies of marriage with Helen: Harold refuses to cede his stance on women both being professionals and wives as he invents a false dichotomy that it is either one or the other. He uses several of the same arguments that Yorke employed in Dr. Zay, including the one that it would be distasteful for a woman going about on her professional duties and then coming home to also tend to the home. Helen, arguing for equality for both the professions along with equality in a marital relationship, refuses his offer.

Following this flashback, we learn several things about the characters. Helen appears content in her career; she extends her case beyond being a mere medical professional but a feminist activist like one of her role models, Margaret Fuller. Harold marries Louise, a woman who is characterized as having the conventional gender roles in the nineteenth-century. While many of the characters debate the efficacies of women entering the workplace, the plot proceeds as Louise grows ill from what is presumably post-partum depression. Helen treats her, but she tells Harold that her best cure would be to have a partner who pays more attention to her; eventually, Louise leaves Harold for another man. The plot ends as Harold expresses that he was wrong to deny Helen her role as a career professional as he concedes the point that both sexes must give and take in a marriage; however, the omniscient narrator reveals that Helen wishes she would have taken his marriage proposal then.

Unlike the other novelists surveyed in this chapter, Meyer incorporates a first-person omniscient narrator, a narrator that by implication resists realism's formal impulse towards a conventional ending. While both Phelps and Jewett believed in incorporating moral messages into their work, they both left room for ambiguity and for the reader to gain moral lessons from 
the subtext. In contrast, Meyer loudly asserts her political points in the novel. Meyer extends her political message far more than even Jewett, who advocated for offering a political message as "silent scripture." While there has not been enough criticism on the novel to offer any suggestions, it is likely a safe conclusion to argue that Meyer has been understudied because of this unsubtle political impulse considering the text lacks any ambiguity. At the same time, nothing that happens in the novel goes out of the realm of possibility, and Meyer is careful to document the conditions various women had. Thematically, Meyer shares much in common with Jane Austen; tonally, her work reads like an antebellum reform text; Meyer even notes this influence of sorts when she characterizes Helen for being a social activist in the same manner as Margaret Fuller.

The literary technique that Meyer uses to accomplish her didactic technique is a commentating narrator. In this text, one cannot separate the narrator from the author as Meyer's voice echoes in the text. This contrasts with the more documentary style of objective narrator in Howells, Phelps, and Jewett. Meyer's narrator comments on the action at hand to the extent that it would be unproductive to record them all in this study, but a few cases are notable. Early in the novel, as Harold tries to get Helen to give up her profession for marriage, the narrator provides a hypothetical speculation of the consequences of such an arrangement:

Suppose she yielded to him, what would the future have in store for them both? Would they be able to crush those terrible moments which would be sure to follow, moments when everyday life would interpose with thoughts of life's earnest duties, of duties forgotten, of powers wasted? There could be nothing of final misery to them, unless marriage could mean between them a long life of 
sympathetic friendship, of self-respect; a union with the consciousness of duty performed. (38-39)

As seen in this passage, the narrator asks pointed rhetorical questions as a literary device to get readers to side with Helen rather than leaving the debate open to interpretation. This passage also not only deals with the issue of gender roles but also medical professionalization. Considering Helen has the talent to succeed in the profession, why should she then give up her "duties" to provide for her patients? The conditional language in the passage also appears selfaware of the predetermined nature of realism. "Suppose" is a coded way of setting up a conditional If A then B proposition, a mathematical logic wherein if these female doctors professionalize, then disequilibrium arises as a result. All throughout the novel, Meyer's narrator asks these pointed rhetorical questions, and sometimes even uses the first-person pronoun I, to not only instill a direct moral imperative into the audience but also to resist the confined strictures of American realism.

Like Phelps's characterization of Dr. Zay, Meyer paints Helen as a nearly perfect heroine who exists in a locus amoenus of her own creation rather than a literal rural haven. Unlike that other depiction, the person who brings with him all the determining social norms is rejected in the beginning; for much of the first half, the novel's disharmony does not come from the female doctor but rather the man she rejected who takes the same ideologies into his next marriage. Harold's marriage to his next wife becomes a subplot that proves disastrous as she finds herself lonely at the amount of time he spends in his political career. The novel contrasts him with Helen, who finds a purpose in her life and understands the implications of her own choices. While Helen does have a moment of weakness in the novel's concluding act, this moment embodies the messiness of free choice rather than a submission to fate: "She longed to cry out, 
'Ask me now to give it all up, even now, when you see how much it means; even now, when you know that the world has a claim upon me, ask me now" (179-80). This novel thus does not even strive towards a sense of formal harmony; Helen did feel something for Harold, but she had to first be true to herself. The fact that Meyer's book is not such a neatly wrapped package with a bow is thus the point.

With these works added together, we thus see Jameson's point that when it came to the idea of expanding the profession, several interpretations clashed on Jameson's Homeric battlefield. Realism's political function as a conservative genre reinforcing existing power dynamics remained true from Howells' perspective as varying webs of determinism prevented Grace from being a professional; these same webs of determinism prevented Dr. Zay from her true calling as she ceded to cultural determinism with its prescribed gender roles. Eventually, we arrive at the point where a sort of counter-realism exists: Jewett insinuates that a person's divine calling overrides any other sense of determinism, while Meyer's novel suggests that women have the free choice to escape prescribed roles from the past. The theme of medical professionalization thus challenged all the assumptions of realism, and the question of what is real and for whom remained ambiguous as all these writers took the logic of the form to its limits. 


\section{Notes}

1. David Shi documents the realist attitudes toward the antebellum romance. Upon reading Hawthorne, Howells, for instance, remarked that his works seemed "so far from time and place that...I could not imagine anything approximate from them; and Hawthorne himself seemed a remote and impalpable agency" (24). Henry James also agreed; while admiring the breadth of Hawthorne's imagination, he stressed that "his (Hawthorne's) principle was wrong... Imagination is out of place; only the strictest realism can be right" (24).

2. Owen Whooley notes a number of causes in his book Knowledge in the Time of Cholera, including: allopathy's regained epistemic legitimacy with the profession's solidification into the American Medical Association (95), along with its successful marriage with German bacteriology, a branch of medicine that homeopaths had rejected (171). Allopathy also was the dominant medical sect during the American Civil War, as allopaths who sat on the Union Army Medical Board refused to let any other sect practice medicine, and they did this despite President Lincoln signing a bill into law allowing homeopaths into the medical corps, as the Executive Branch was too occupied to enforce the law.

3. The American Medical Association commissioned Abraham Flexner to visit medical schools and report on them in an attempt at standardizing the profession. One reason for this was to send funding from Carnegie and Rockefeller to notable institutions. Flexner emphasized a rigid allopathic education, including a "competent knowledge of chemistry biology, and physics" (25). Flexner also emphasized another year of curriculum to allow for practical on top of theoretical experience, which was partly a response to criticism that clinical allopathy neglected the patient. Following his report, the AMA wielded considerable power in certifying new practitioners.

4. In his novel The Rise of Silas Lapham, published four years after Dr. Breen's Practice, Howells further explores these themes. Silas Lapham, a burgeoning capitalist, finds himself struggling to grow accustomed to New England high society, and much of the novel centers on his conflict to enter it as even with his money, he is still an outsider, and he remains an outsider by the novel's end as his new house near Boston's high society burns to the ground. The novel again features a marriage subplot as Mr. Corey, a young aristocrat, courts both of Silas's daughters, Irene and Penelope. The novel offers a resolution of sorts as Silas's daughter, Penelope, wins the marriage contest between she and her sister, Irene, due in part because her more refined social demeanor and ability to partake in conversation gives her the upper hand as Irene is characterized by her beauty alone. With this ending, a symbolic marriage of sorts happens as the New Wealth, the Laphams, meet the Old Wealth, the Coreys. In her article "For Love or Money: Courtship and Class Conflict in Howells' The Rise of Silas Lapham," Hsin-Ying Li articulates this symbolic wedding best when she notes that "the wedding and the new generation finally signify a family reunion of exemplary Americans, the mystical rebirth of the cultural traditions, and the creation of an open society-not a classless society 
perhaps, but one in which the classes, like the spouses of Howells' realistic marriages, must live together through affection, jealousy, estrangement, and acceptance" (120).

5. See Frederick Wegener's introduction to the Penguin classics edition of A Country Doctor. Joseph Church psychoanalyzes Nan, and Jewett, through a Freudian perspective in an article "The Healing Arts of Jewett's Country Doctor."

6. Marjorie Pryce examines the novel through the lens of regionalism, and she reads Nan's hybridity as both urban and rural dweller as a new construction of modernity both in terms of the national level and as a "New Woman" for a new age. In Rural Fictions, Urban Realities, Mark Storey examines the novel through the lens of urban (scientific) medicine versus a more rural, patient-centered model.

7. Meyer's medical novel, Helen Brent, M.D, has been brought up only a few times by literary scholars even as scholars like Davis have synthesized formal criticism with New Historicism. In a chapter in her 1997 book Women Healers and Physicians, Lilian Furst mentions the novel a couple of times alongside her discussion of Howells, Phelps, Jewett, and Henry James's The Bostonians. In his afterword to Phelps's Dr. Zay, Michael Sartisky also discusses the novel's treatment of the marriage plotline. Other than that, most of the conversation on Meyer has come from historians who treat her novels as primary documents for the women's suffrage movement and for her role in founding Barnard College, a private liberal arts institution in New York City. 


\section{Chapter 3: 'Ain't I a Doctor?': Medical Professionalization \& the Disenfranchisement of the Individual in Selected Texts of American Literary Naturalism}

The issue of medical professionalization and standardization became, in the final decades of the Nineteenth Century, such a polarizing issue that it reached the United States Supreme Court in Dent $v$ West Virginia(1889). Frank Dent, a physician of the eclectic sect, a group that slightly differed from conventional allopathy, found his medical license removed due to West Virginia passing a law requiring a physician to either have a degree from a reputable college, have practiced medicine for over ten years, or else pass a certifying examination. Dent's degree from the American Eclectic Medical College was ruled not sufficient by the West Virginia Board of Health. By 1882, when the law was passed, Dent had only practiced medicine since the passage of his degree in 1876, and thus he found himself at the mercy of the certifying board who deemed eclectic medicine not reputable. The Court unanimously ruled in West Virginia's favor, noting that states had the right to impose professional standards, and only when such standards "have no relation to such calling or profession, or are unattainable by such reasonable study and application" can they then "deprive one of his right to pursue a lawful vocation." In other words, only when the standards have no relation to the job can they then be deemed unlawful by a federal court. Furthermore, states could impose such restrictions on physicians as a profession because of "due consideration, therefore, for the protection of society." These newfound standards became commonplace not only in medicine but also in other professional guilds during a time that historians often label as the Progressive Era. While many Progressives sought to protect Americans from the ills of industrialization through professionalization, others found respite in protecting Americans from the overreach of government authority at the local level. Despite the Court's ruling settling the issue of medical professionalization from a legal 
standpoint, the issue persisted, however, as many juries across the country refused to prosecute doctors after their licenses were stripped (The History of Dentistry 680).

A literary movement that chronologically emerged at the same time as Progressive politics was American literary naturalism, and at its core, naturalism politically engages with the social tensions surrounding professionalization in the late nineteenth century by romanticizing those disenfranchised by its exclusionary politics. Unlike the gothic, a mode that often remained ambivalent at endorsing either allopathy or alternatives to it, or even realism, a mode that showed complicity with emerging new class structures, American literary naturalists displayed a tendency to resist the newly accepted medical establishment and to show, often in tragic form, the decline of either competent medical practitioners following medical professionalization laws or showing the patient becoming a victim to the mainline medical establishment. The structure of naturalist polemical novels therefore suggests an inherent contradiction in Progressive politics. In an ideal politics designed to help improve the lives of ordinary Americans by emphasizing professionalization, Progressivists make the situation worse by closing the profession to interested outsiders. The naturalist novels and short fiction surveyed in this chapter demonstrates how many agents, from dentists to women to even nonhuman beings, cannot thrive on their own merits because Progressive politics is built on protecting the profession as a group unit, not the individual members affected by it.

This chapter surveys three different moments in literary naturalism. The first examines Charlotte Perkins Gilman's reaction in "The Yellow Wallpaper" not only regarding Weir Mitchell's standards of care but also how her text embodies a change in ideology from the city mystery novel to naturalism with its critical difference from Mitchell's novella Autobiography of a Quack. While Mitchell's project is different in that it solidifies the emerging new power 
structure, allopathy, by firmly critiquing the alternatives, it takes a rhetorical tone that sharply differentiates it from other forms; thus, Mitchell is a sort of proto-naturalist and Gilman appropriates his politics to show how professionalization disenfranchised the patient. Frank Norris's McTeague likewise illustrates the dangers of professionalization by showing the decline of McTeague, a dentist who loses his ability to practice because he never possessed an approved state certification. Norris's narrator goes to great lengths to show that while McTeague learned the trade from a charlatan, he nevertheless is a competent dentist, and the extent to which the book documents McTeague's downfall illustrates naturalism's romanticizing of the individual; McTeague degenerates from a respected local civilian to an outlaw ruled by his baser instincts. The chapter concludes with a few works from John Steinbeck. Steinbeck saw the injustices committed to migrant workers by trained medical professionals during the 1930s Dust Bowl migrations, and as his thinking evolved over the 1930s, he gradually associated professionalization with an idea he coined as teleological thinking, a shortcoming in seeing reality. His short story "The Snake", while leaving much to the imagination, showcases a scientist professional whose limited perspective illustrates his lack of empathy for nonhuman subjects; the story suggests that professional ethics and its ambition for knowledge has little regard for the patient, and this message is exacerbated by the fact that the patient is a lab rat and not a human being with whom the reader could more easily sympathize. The Pearl also features a medical professional whose one-sided thinking about financial gain almost causes the death of Kino's son. Furthermore, the chapter looks at Steinbeck's screenplay “the Forgotten Village," a work written immediately after The Grapes of Wrath that documents the rise of modern medicine in Mexico and the injustices committed in doing so. Steinbeck wrote at a time when the profession had won the debate against outsiders; however, his fiction nevertheless shows through 
its critical tone the remaining social anxieties left over concerning the professionals' perceived lack of care for patients.

\section{II: The Move Toward Medical Professionalization in the Late Nineteenth Century}

America effectively industrialized in the late nineteenth century and into the twentiethcentury in a time coined as the Gilded Age. Unlike the Jacksonian era, a time when the nation's wealth was the most evenly distributed, most of the nation's wealth made its way to the top one percent. With this came numerous problems, from child labor to exploitative wages to tight living conditions to the lack of sanitation in some areas of the growing American city.

Considering these emerging social ills, documentary texts such as Jacob Riis's 1890 text How the Other Half Lives and Upton Sinclair's 1906 book The Jungle thus arose to criticize such problems as "municipal corruption, life in the urban slums, child labor" and "industrial production and monopoly" (Flanagan 141).

Despite this tendency, an emerging middle class of professionals found their footing in the century's latter half, and they did so by protecting their interests through professionalization. Historians have often labeled this move toward professionalization part of "the Progressive Movement," along with other moves checking the rise of unregulated capitalism with the power of government. Regarding this emerging new middle class, historian Robert Wiebe notes that "the specialized needs of an urban-industrial system came as a godsend to a middle stratum in the cities. Identification by way of their skills gave them the deference of their neighbors while opening natural avenues into the nation at large" (113). Furthermore, this new middle class forged itself by fiercely defending its interests through "increasingly formal entry requirements into their occupations (that) protected their prestige through exclusiveness" (113). Following the Civil War, where despite having medical shortages alternative practitioners were not allowed to 
practice, allopaths succeeded in creating an organizational apparatus, the American Medical Association, to bar any outsiders from gaining equal status with its members (Whooley 105). With regards to professionalization, several other groups also emerged around the Civil War, including, as will be relevant in this study, the American Dental Association in 1859 (ada.org).

Although this chapter primarily deals with medicine, it must be noted that other professions also organized, from plumbers to writers to college professors needing doctoral degrees as a symbol of their cultural capital (Heddendorf). While it took decades for the American Medical Association and other professional organizations to gain authority, the social conditions of industrialized America paved the way for their organizational legitimacy. Professional medical practitioners, dentists, and others found themselves defending their status as a burgeoning new middle class by enforcing rigorous new standards along with denying entry into their professions from outsiders. With regards to medical school admissions, institutions like Harvard and Johns Hopkins, despite losses in enrollment, began to increase medical school standards by the end of the century, eventually culminating in them becoming four year programs (Miller \& Weiss 352). In the latter half of the century, an organization called the AAMC (The Association of American Medical Colleges) formed, and the group endorsed a minimum three-year curriculum; by 1893, 96 percent of all medical institutions met the requirement (353). By the end of the century, almost all states required licensure to be able to practice medicine, which in turn created a rigid, structured state apparatus involving government approval to practice.

Although the medical trade wanted to exclude practitioners without the proper credentials, they faced scrutiny from the public, especially in rural areas devoid of care who needed anyone. Most states considered it a misdemeanor to practice without licensure, but many 
physicians practiced nevertheless, as exhibited by the 1910 text The History of Dentistry: "the constituted guardians of the law have their time so much engrossed with greater offenders that dental misdemeanors are many times neglected because there is no time to look after them" (680). A plethora of litigation arose on the issue; the most relevant ones include an 1889 case in New Hampshire, which declared licensing practices illegal (681). Other litigation brewed about state licensing boards refusing to allow graduates from certain schools to practice; the burden of proof towards this end fell towards the professional to show that his license was reputable (687).

Because allopathy allied itself with bacteriology, they found with this scientific breakthrough a complete epistemological shift in how the patient was treated. ${ }^{1}$ Owen Whooley notes that "whereas bedside empiricism, as practiced in the United States, was a passive epistemology based on the observations of sensory experience, the laboratory subscribed to an interventionist epistemology" (192). As a result, the patient became a less important agent in treatment as he/she "forfeited nearly all control over defining the disease to experted opinion (Katz 2002). With this new epistemology, homeopathy lost much of its legitimacy in the medical sphere; however, many patients still sought a more personalized form of care that located them as the center of attention; therefore, homeopaths found work serving as personal physicians for wealthy families and as country doctor figures.

The final move that settled the debate about medical standardization would come about through Abraham Flexner, a man who was commissioned by the American Medical Association to report on the standards of healthcare. As much as one man can influence proceedings, Flexner did so; medical schools hoped that he might be able to steer Carnegie aid their way (Lynn \& Weise 361). Even once the Report was published, Flexner took a position with the Rockefeller General Education Board, which allocated funding to medical schools (363). In his report, 
Flexner derided the apprenticeship system that still lingered (3). Despite the quality of some doctors who went to quality institutions, no other country besides America featured "so great a distance and so fatal a difference between the best, the average, and the worst" (20). As aforementioned, doctors who only received an apprenticeship often congregated to rural areas. For example, Kentucky, Flexner's home state, had a ratio of 1:624—doctors per residents (17). Despite this already low number, Flexner advocated to produce fewer and better doctors with a higher rate of education than even states required, and if this included shutting down medical schools to do so, all the better.

Becoming a doctor, Flexner argues, should require not only a license to practice medicine but also a thorough understanding of the scientific inquiry needed to be a good doctor. The apprenticeship system was not the only issue with medical practice that Flexner cited. Medical schools, which grew at extremely fast rates in the nineteenth century, did not offer proper empirical training either, and each school's expectations differed. To solve this problem, Flexner suggests that everyone admitted to medical school should have a "competent knowledge of chemistry, biology, and physics. Every departure from this basis is at the expense of medical training itself' (25). Without this training, medical schools need not admit prospective applicants. Furthermore, he argued that after the first few years of education, medical schools should require a "fifth or hospital year" to gain practical experience (48). Flexner provided a model for medical reform that insisted on the standardization of medical care; medicine should not be a trade but a profession. Beyond that, Flexner turned the medical system into an ideological state apparatus, since medical schools had to meet his ideology to get the requisite funding they needed. Following Flexner, these debates dissipated; state government and the 
AMA would be responsible for regulating the standard of care in the profession by forcing anyone who did not have proper certification to abandon their practice.

\section{III: American Literary Naturalism \& The Politics of Professionalization}

American literary naturalism has suffered with an identity crisis in literary criticism as debates have occurred asking a number of questions: what is naturalism? How is it different from realism, if at all? What works and authors should be included within a naturalist taxonomy? In a dissertation about the role of professional politics in literary form, this chapter follows from a line of inquiry started by Eric Carl Link, who argues that "naturalism is dead" (1). He claims that "it is theme, rather than genre, methodology, convention, tone, or philosophy, that qualifies a text for inclusion in the 'school' of American literary naturalism" (18). Form and theme are thus synonymous with the discussion of naturalism, and this chapter investigates the degree to which the theme of medical professionalization shaped the naturalist mode.

Of particular interest here is Link's association of naturalism with the gothic romances of writers like Hawthorne; while naturalism is often associated with realism, it is the romance that offers a greater degree of truth: Link quotes Norris who argues that realism is "the drama of a broken teacup, the tragedy of a walk down the block," whereas the romance rests in "the wide world for range, and the unplumbed depths of the human heart, and the mystery of sex, and the problems of life, and the black, unsearched penetralia of the soul of man" (50). It is naturalism's association with the gothic, which, as David Reynolds points out, is a form that has roots in melodrama, that gives it a unique political fervor. Critic Keith Newlin notes that naturalism employs "the narrative device of melodrama as an efficacious means to convince readers of the truth of their theses and to elicit sympathy for their protagonists...or prompt readers "to take action to redress social imbalance" (qtd in Wells 5-6). Elements of what we associate with the 
naturalist novel, including "sensational storylines, the overreliance upon narrative coincidence, the authorial intrusions, the emotional overload," are likewise melodramatic elements. It is this chapter's goal to showcase how, in its melodramatic emphasis on individuals being harmed by professionals, that naturalism at the very least embodies a profound sense of thematic skepticism to professionalization, and as a form, it more than any other represents the harm to not only doctors disenfranchised by newly formed certification laws but also patients whose best interests are not taken into consideration by a profession that values scientific innovation over the needs of individual patients.

Over the decades, critics have widely diverged on what naturalism is, but the classic textbook definition can be traced to Malcolm Crowley, who conceptualized the mode as "pessimistic determinism" (414). By this definition, Cowley argued that the naturalists "have no faith in reform, whether it be the reform of an individual by his own decision or the reform of society by reasoned courses of action (429). This differentiates the naturalists in Cowley's eye from the proletarian and Marxist novelists of the 1930s, whom Cowley thought believed that "men acting together could make a new world." Whenever naturalism is taught in most American literature surveys, it is safe to say that Cowley's definition has retained the most prominence as the definition of naturalism being an overly pessimistic extension of realism where uncaring social forces like economics or ruthless nature persists feature commonly anthologized choices being works like Stephen Crane's “The Open Boat” or Jack London's “To Build a Fire" to illustrate these tendencies.

Since the 1980s, scholars of naturalism, arguably more than in other modes, have asked questions about the extent to which the form owes its tendencies to political movements in the late nineteenth-century. In her influential 1985 study Form and History in American Literary 
Naturalism, June Howard argued that naturalist texts have a philosophy of proletarianization, a social anxiety "traditionally associated with although certainly not limited to the petty bourgeoisie who, possessing small capitals or professional skills, passionately defend their narrow footholds of economic security" (95). Similarly, with the rise of new historicism in the 1980s, Walter Benn Michaels wrote one of the most influential treatises, The Gold Standard and the Logic of Naturalism, where his argument finds homologies between the cultural currents of the gold standard debate and the form of naturalism. One of Michaels's central arguments was that naturalism is so embroiled within the currents of late nineteenth century politics that any discussion of naturalist form is political; the gold standard debates and the naturalists' symbolic thinking both showcased common links with one another. Relating to previous discussions concerning the form of naturalism, Michaels notes: “(Naturalism) has been caught up in endless theorizing about the nature and very possibility of realistic representations...these questions seem to me to posit a space outside the culture in order then to interrogate the relations between that space....and the culture" (27). In building a logic of naturalism, Michaels thus sets out to "map the reality in which a certain literature finds its place and to identify a set of interests and activities that might be said to have as their common denominator a concern with the double identities that seem, in naturalism, to be required" (27). As we shall soon see, much of this chapter extends from Michaels's important readings of "The Yellow Wallpaper" and McTeague to the politics of professionalization. This work follows from the important points Michaels makes regarding locating literature within the culture that it originated; the point that naturalism is political is thus a premise that this chapter accepts.

Despite the important work of critics like Michaels, other critical voices have lamented the loss of rigor concerning discussions of literary form within these historical arguments. 
Donald Pizer, a critic of naturalism a generation before Michaels, argued that Michaels's argument featured many empty platitudes: "the prose uses a presumed rhetoric of persuasiontextual documentation and analogical proof - to maintain unsupported conclusions about the participation of a literary work in its culture" and that a reader is "sandbagged by the writing rather than of being informed and convinced." While Michaels's work helped to instigate a political tendency in naturalist scholarship, Pizer points out that new historicists either do not give enough historical evidence or focus on form enough for the sweeping claims made, yet the clever rhetorical devices in the writing helps to disguise it. This work takes this criticism in mind as it seeks to unify the form of naturalism with some of its political tendencies, in this case professionalization, that disenfranchises the individual.

Recent studies have also revealed the extent to which naturalism represents social conditions. Ira Wells's recent study Fighting Words: Polemics and Social Change in Literary Naturalism contends that the polemical work of Dreiser, London, and others in muckraking newspapers helped to shape the structure of naturalist fiction. He argues that "naturalism is a less a coherent philosophy than it is an attitude, a posture of aggressive controversy, which happens to cluster loosely around philosophical themes..." (35). Rather than melodrama, Wells reads these writers as polemicists because of sensational essays they wrote for newspapers in an age where yellow and "new" journalism emerged (6). He reads the political lives of writers like Dreiser, who joined the Communist Party, and Richard Wright, as having a direct impact on their work. Examples of texts that Wells reads as polemical include Frank Norris's The Octopus, Theodore Dreiser's An American Tragedy, and Wright's Native Son. Wells's work has invited some criticism in the vagueness of the term and the lack of evidence he uses in arguing for naturalism as polemic. ${ }^{2}$ 
This chapter does not go as far as Wells as arguing that naturalism is polemic with regards to the themes of professionalization; however, it does contend that naturalism melodramatically represents how the individual is affected by larger forces . The premise that naturalism is inherently a political, rhetorically charged mode likewise applies to this argument. The politics of medical professionalization gave writers a chance to represent the injustices committed against individual agents, whether it is the disenfranchised doctor or the patient, and the melodramatic elements are meant to elicit sympathy for these characters. These texts thus suggest that these individual characters are victims of a larger social phenomenon. In this case, it does not matter so much what type of medicine is represented; what does matter is that the process of professionalizing medical science was an imperfect one that left many people disenfranchised. Because the naturalist mode is built on a foundation featuring melodrama, the naturalist mode, more than any other form, gave these disenfranchised voices a place within the American cultural zeitgeist. In contrast with the other forms across this dissertation, the naturalist mode's way of representing the professionalization conflict is too political to be gothic, too rebellious to be contained within realism, and too serious to be satire. While this chapter is thus not the first example of reading naturalism as both political and melodramatic, this work is unique in showcasing the extent to which naturalist texts used the medical profession to represent the disenfranchised individual.

\section{IV: S. Weir Mitchell's Effect on Charlotte Perkins Gilman's Naturalism}

Reading Charlotte Perkins Gilman's “The Yellow Wallpaper” as literary naturalism is an exercise in the futility of classification, as the story could be classified as well under the gothic tradition, including that mode's evolution into a gothic grounded in realism from the likes of writers like Henry James. However, with this dissertation's extrapolation of naturalism as a 
populist melodramatic form that showcases the exclusionary practices of professionalization, we can classify "The Yellow Wallpaper" as naturalism. To embody this populist politics, the naturalist form takes a pattern in representing the lack of care that the professional physician gives the patient along with the physician's blatant dismissal of the narrator's symptoms. Historically speaking, the political resistance to professionalization also fits within the traditional chronology of naturalism growing popular in the 1890s. The story revolves around the nervous breakdown of its narrator, who, following Dr. S. Weir Mitchell's rest cure, disintegrates into madness as she finds herself a prisoner of a room with hideous yellow wallpaper. While much historical commentary has been spent in discussing Mitchell's role in the story, little to no attention has been paid to Mitchell's work as a novelist and the role that these works had on Gilman. This chapter argues that Mitchell's 1867 novel The Autobiography of a Quack likely played a role in shaping the political function of Gilman's story. We can classify this text as a sort of "gothic realism" in the way it represents the injustices committed by alternative physicians on unsuspecting patients; of all works surveyed in that chapter, it most resembles Hawthorne's “The Haunted Quack.” While Mitchell's tale has more in common with realism in the way that it solidifies the burgeoning new power structure, allopathic medicine, following the Civil War, its political overtone embodied itself in Gilman's naturalist story that firmly criticizes the professional medical establishment that has little to no concern for the patient. The anxiety of Mitchell's influence thus found itself looming over the story written to criticize his own practices.

Unlike Norris and even Steinbeck to an extent, Charlotte Perkins Gilman has evaded classification into a certain literary genre, but some work has been done in locating her within the naturalist paradigm. While the "Yellow Wallpaper" has been discussed for its implications 
to gender politics along with discussions regarding Mitchell's rest therapy, it, besides a few exceptions, has rarely been examined for its larger political subtext. One such exception is the introduction to the landmark book The Gold Standard and the Logic of Naturalism, where Walter Benn Michaels articulated the political dimensions of the tale that builds on the previous studies done by feminist critics. The main point of his political argument locates Gilman's narrator within the social structures of burgeoning capitalism: Gilman's narrator goes mad because she cannot produce in an American society that was growing obsessed with consumer capitalism: "For Gilman then, the work of writing is the work simultaneously of production and consumption...her (the narrator's) nervous breakdown marks for Gilman the triumphant omnipresence of market relations" (13). Even in the first page of his essay, Michaels notes that "Gilman's polemical point in insisting on the absolute priority of production is, of course, to emphasize the unnaturalness of an economic system that denies 'free productive expression' to 'half the human race" (23).

What is significant about Michaels's study to this one is his insistence on locating literature within culture rather than removing oneself from it as happens with studies that focus on the distinctions between naturalism and realism. Michaels's implicit argument behind this statement is that naturalism is so embroiled in its politics that it cannot escape them in any discussion of its form. Michaels's argument does not go as far as to argue that a certain politics drives the naturalist aesthetic, however, except in suggesting that Gilman subtly endorsed material capitalism; his chapter on "the gold standard" and McTeague also showcases how that historical event is represented in the novel, yet it doesn't quite make an argument regarding the implications to naturalist form beyond pointing out the political representations. While Michaels does not take his argument as far as Ira Wells later would in claiming that polemics drives the 
naturalist form, it is noteworthy that he uses the word "polemical" to explain the story's driving structure in making its overt case for the need for productive labor in a world obsessed with material production. This work builds off Michaels's examination of the story to illustrate how the cultural production of Mitchell posited an unlikely influence on Gilman in creating the unique naturalism of "The Yellow Wallpaper."

\section{S. Weir Mitchell's novella The Autobiography of a Quack appeared in the Atlantic}

Monthly in 1867, and until recently with the re-discovery of Mitchell's novels in large part due to the rise of the medical humanities, his work has fallen out of print along with critical discussion of it. Mitchell was among the most prominent of physicians in his era; in an era of professionalization, he was the exemplary professional. Among his honors, he was the first president of the American Neurological Society, and he also served terms for the Association of American Physicians, the American Association of Physicians and Pathologists, the Congress of American Physicians and Surgeons, and the College of Physicians of Philadelphia ("Silas Weir Mitchell"). Mitchell began practicing as early as the 1850s; thus, by the time Autobiography of a Quack emerged in 1867, Mitchell already had a prominent reputation; therefore, it is a reasonable inference to deduce that his medical fiction had the political function of endorsing the need for professionalization.

Classifying this novella into any one mode is a weighty task: Mitchell's narrator, Dr. E. Sanderaft, is a first-person narrator reminiscent of the gothic texts of Poe's unreliable narrators as he gloats over the ways he dupes patients. Yet the text also has undertones of realist representation; nothing happening in it is outside the realm of possibility, and its political function has a conservative effect that is never directly spelled out: the need for professionalization exists to prevent someone like Sanderaft from experimenting on patients. 
What happens with Gilman's text flips the script: she borrows the same first-person narrator from the gothic tradition, yet her text showcases the extent to which the profession disenfranchises a patient; her narrator has no power to challenge the wide variety of professional voices that silence her concerns. While this section stops short in arguing for a direct influence, as Gilman's reading history has not been documented in the research, it does suggest that an uncanny similarity exists between the two authors. Gilman wrote to Mitchell, as Denise Knight's publication of her letter to him illustrates. To make sense of the ordeal she faced, it is possible that Gilman unconsciously inverted the form from Mitchell's fiction to create an alternative text, a political text of resistance showcasing how she was silenced. And this political text found itself in a literary marketplace with others like it that showcased the individual's disenfranchisement.

Mitchell's novel showcases the ugly underbelly of not only the white-collar crime of Sanderaft but also the amount of blue-collar crime in Philadelphia and numerous other places in America at the time. By illustrating the sheer amount of crime happening, Mitchell not only creates a platform of calling for reform in general but also he calls attention to the fact that in the liminal space of Antebellum and Civil War America, anyone could claim to be a professional since professionalization had not yet occurred en masse. Sanderaft describes the space where he practices:

it was then filled with grog-shops, brothels, slop-shops, and low lodginghouses...the blacks predominated, and had mostly that swollen, reddish, dark skin, the sign in this race of habitual drunkenness. Of course only the lowest whites were here-rag-pickers, pawnbrokers, old-clothes men, thieves, and the like. All of this, as it came before me, I viewed with mingled disgust and philosophy. (13) 
This passage is loaded with racist and classist subtext as the narrator fears the African American population as well as con-artists, pawnbrokers, and thieves. Considering the text's 1867, postCivil War production, it seems intensely skeptical of any social change toward urbanization. However, in such a space, the novella's implicit argument is that white crime can go unnoticed with larger social problems lurking on the surface.

The plot in Mitchell's novella centers on E. Sanderaft's malfeasance as a medical practitioner, and considering Mitchell was a dedicated professional practitioner, it made sense for Mitchell to endorse the power dynamics in which he was an active member. In the opening pages of the novel, the narrator outlines the lackluster standards in medical education: "As to my studies, the less said the better. I attended the quizzes, as they call them, pretty closely, and being of a quick and retentive memory, was thus enabled to dispense with some of the six or seven lectures a day which duller men found it necessary to follow" (11). Sanderaft also mentions how he refused to do any dissection: "if a man took his tickets and paid his dissection fees, nobody troubled himself as to whether or not he did any more than this." It also did not matter if one graduated or not from these lectures: "a like evil existed at the graduation: whether you squeezed through or passed with credit was a thing which was not made public, so that I had absolutely nothing to stimulate my ambition" (11). As a physician novelist documenting all these problems with medical education, Mitchell creates a narrator aware of his complicity in conning the general American public. It also sets a political tone in that the reader cannot sympathize with Sanderaft considering that the reader is aware of the author's own stake in the matter. While postmodernism has taught us to separate an author from the created text, it is impossible to do so with this text considering Mitchell's own stake in his fictional representation. The connection between author and politicized text would also true of Gilman. 
Mitchell also takes the time to dismiss a number of alternative medical practices in his argument for the need for professionalization, as Sanderaft pretends to be a homeopath, a healer who uses electricity, and a spiritual healer across the novella. Nowhere does Sanderaft endorse these practices, but instead he satirizes them and celebrates his brilliance at having once gotten away with his quackery. Take for example a passage where Sanderaft elaborates on homeopathic remedies: "I believe one hundred quack remedies fail for one that succeeds...I think I shall one day beguile my time with writing an account of the principal quack remedies which have met with success. They are few in number, after all...”(62). In another case, Sanderaft and another homeopath, Dr. Zwanzig, the name of which being a play on homeopathy's German origins, discuss the case of a consumptive man who lost his leg, and they seriously discuss how much aurum to give the patient so as not to overdose him because of his lost leg (33). Despite Sanderaft's asides being similar to a stage-machiavel like Richard III bragging about getting away with his crimes on the Renaissance stage, he does not escape scrutiny as his malfeasance also gets him into trouble with not only criminals but also self-aware patients. One instance occurs when a criminal boss wants Sanderaft to help him escape from the gallows, and Sanderaft devises a solution based on hearsay from a man who supposedly escaped with some medical intervention by cutting a hole in his windpipe, allowing the breath to go in and out of the opening below the noose (38). Sanderaft must flee to retribution for his complicity in this area. Sanderaft also consults spirits to tell an old man his son was stealing from him, to which the son proves his innocence. He then mentions that he "endured a beating such as I would have hesitated to inflict upon a dog" (54). With this case, Sanderaft loses his luck and must flee from getting lynched. 
All of these cases structurally work to create an argument to the reader for a need for a professional apparatus to monitor cases like Sanderaft. Again, the separation between author and the created text is not so far removed, as Mitchell's professional reputation grew more solidified by creating a character that wantonly shows the absurd nature of these alternative practices along with their ill effect on the patient who not only may or may not receive help but also patients who lose their money to this charlatan. The whole tone of this city-mystery novel endorses professionalization in a strong way, and it ends with Sanderaft's imminent death at the hands of Addison's Disease, a disease affecting the adrenal glands, an ailment that Sanderaft deems a “doctor's trick, and one I had tried often enough myself” (70-71). This diagnosis comes from a learned physician, and while it's ironic that learned science and quackery intertwine in this case, it is significant to the novel's argument that in a new world following the end of the Civil War, a time of such transitional impact for medicine, the allopath survives and the quack literally dies.

By 1892, when Gilman published “The Yellow Wallpaper”, allopaths like Mitchell dominated the medical marketplace, as alternative practitioners were losing their credibility due to state certification laws. Mitchell became one of the existing establishment's leading voices, even in becoming President of the Association of American Physicians, another epistemic group resembling the American Medical Association. As aforementioned, Gilman's tale follows her narrator's descent into madness as she begins noticing shapes in the wallpaper as she underwent Dr. Mitchell's rest therapy, a figure whose presence is explicitly mentioned in the text: "John says that if I don't pick up faster he shall send me to Weir Mitchell in the fall” (796).

Like Mitchell's work in The Autobiography of a Quack, it proves difficult to separate text from author as Gilman's narrator in "The Yellow Wallpaper" largely constructs an argument for the need for greater awareness not only concerning post-partum stress but also the need for 
productivity to be a contributing member of society. The story's larger themes stirred up controversy, as Gilman noted that "a Boston physician made protest in The Transcript. Such a story ought not to be written, he said; it was enough to drive anyone mad who read it" (804). On the other hand, a doctor from Kansas wrote to her noting that "it was the best description of incipient insanity he had ever seen, and — begging my (her) pardon, had I been there?" Gilman chronicles her entire story; the cure for her melancholia was the rest cure, which included being separated from her child; and after concluding nothing was the matter, Mitchell advised her to 'live as domestic a life as far as possible,' to 'have but two hours' intellectual life a day,' and 'never to touch pen, brush, or pencil again." After a friend advised her to work again, Gilman states that she recovered "some measure of power." Her fiction then had "embellishments and additions to carry out the ideal" and that "it was not intended to drive people crazy, but to save people from being driven crazy, and it worked" (804). While the pessimistic determinism of naturalism could be interpreted as pessimism for pessimism's sake, it is significant that Gilman admits her project not only had a political point but also that her activism worked, as Mitchell had "altered his treatment of neurasthenia since reading "The Yellow Wallpaper" (804). Thus, unlike the gothic, which was content with representing the problem, and realism, which tended to have a political function, this work of naturalism succeeds in calling the reader to some sort of political action.

This argument suggests that the act of explicitly mentioning Mitchell serves as a linguistic marker to the same kind of project Mitchell was taking up in his text. Reading both works together yields intriguing possibilities with regards to understanding naturalism's political, melodramatic tone. One way that the two texts prove similar is with unreliable, first person narrators. Both Sanderaft and the "Yellow Wallpaper's" narrator are constructions that are out to 
prove the respective authors" arguments. Like Sanderaft, the narrator of "The Yellow Wallpaper" also concludes the tale with an ambiguous ending; Sanderaft supposedly dies but is writing from beyond the grave, and Gilman's narrator, having fallen into madness, writes from some moment transcending the barriers of space and time; she notes that she had already 'come out of the wallpaper' and asked why her husband fainted (803). The first-person narrative voice from Mitchell's narrative closely resembles the uncanny ending to this tale, a genealogy further illustrating naturalism's roots with an earlier generation of gothic romances. Formally speaking, the narrator's mentioning of Mitchell in the text serves the same function as Mitchell's unstable narrator posing as a homeopath or a spiritualist in that it proves instrumental to the overall political logic of the tale.

From the opening section of the story, the politics of professionalization are at stake. In Gilman's text, we see inside the domestic sphere where the physician's cultural capital allows him unprecedented access to wrongly treat his patient. Noting that her husband John does not believe she is sick, the narrator asks, "What can one do? If a physician of high standing, and one's own husband, assures friends and relatives that there is really nothing the matter with one but temporary nervous depression—a slight hysterical tendency—what is one to do?" (792). Even worse for the narrator is that her "brother is also a physician, and also of high standing, and he says the same thing" (792). The opening descriptions of the narrator's powerlessness against these professional men showcases how professional authority is at complete odds with individual autonomy. As if being trapped in the nineteenth-century domestic sphere is not confining enough, the narrator also must contend with the epistemic legitimacy of the established profession. Before the narrator is literally trapped gazing at the yellow wallpaper, she is thus already trapped by professional forces. This passage ends with her remark: "Personally, I 
disagree with their ideas. Personally, I believe that congenial work, with excitement and change, would do me good. But what is one to do?" This passage is central the story; the narrator has no voice or course for appeal when surrounded by so many professionals.

Considering John is a doctor, the class politics of renting a comfortable house for a summer vacation also prove stifling to the narrator. In the first passages of the story, she remarks that she and John renting in a colonial mansion, a hereditary estate, and considering his occupation, "perhaps that is one reason I do not get well faster" (792). In describing the property, she notes that "there was some legal trouble, I believe, something about the heirs and co-heirs; anyhow, the place has been empty for years. That spoils my ghostliness, I am afraid, but I don't care - there is something strange about the house-I can feel it" (793). A number of interesting elements are at here: it threatened the American status quo to see this professional class arise and take the same status symbols, large mansions, that formerly belonged to the older American wealthy elite. Professionalization in itself acts as an exclusionary device to protect this new upper middle class, so having this family live in a secluded mansion serves as a device to show the increased distance between doctor and patient, and in this case, it's the most intimate of patients in his spouse. Having John as a physician in addition to the threat of Dr. Mitchell also amplifies the fear of the network of these connections. The threat from these professional connections further amplifies the story's overall sense of claustrophobia that the narrator feels from the wallpaper.

This distance between doctor, patient, and the other social classes excluded by professionalization is further amplified with the narrator's gaze outside a window: "There is a beautiful shaded lane that runs down there from the house. I always fancy I see people walking in these numerous paths and arbors...(John) says that with my imaginative power and habit of 
story-making, a nervous weakness like mine is sure to lead to all manner of excited fancies" (794). This scene further builds on the idea of a literal and metaphorical distance between an estate owned by the physician in this house along with the people outside of it. The narrator could interact with these people even on a fictional level, but John's resistance to any sort of fancy extends beyond the rest-cure to the notion of professionalization itself. Being alone in this house and not interacting with the ordinary people becomes an important dynamic to protecting John's professional reputation in that if anyone sees the narrator, his reputation could be threatened. In this way, John's fainting in the final moment of the narrative as he sees the narrator crawling on the floor symbolizes the consequences for a patient whose needs are so far removed from the professional physician that she now defies clinical representation.

While the gothic represented ambitious doctors whose zeal for knowledge came at the expense of the patient, it is significant that Gilman's form of naturalism puts agency into the hands of the patient instead of showcasing the patient as a passive agent. At its core, Gilman's "The Yellow Wallpaper" does maintain that same pattern from those more gothic stories. It's likely not without significance that just as professional medicine solidified its power, gothic tropes again re-emerged to represent the lack of care shown to the patient; however, the more overtly political fervor of naturalism showcases the patient's need. At its core, this story showcases the naturalist trope of the individual's powerlessness against larger deterministic forces; however, that trope raised awareness about the extent to which the profession silenced women's voices. Gilman herself acknowledged the story's structural advocacy for the patient when, in "Why I Wrote the Yellow-Wallpaper," she states that "It was not intended to drive people crazy, but to save people from being crazy, and it worked" (804). If it is theme that defines naturalism, as Eric Link argued, then we see the logic of professionalization ruthlessly 
criticized in Gilman's story as the patient disintegrates into madness despite an alarming amount of epistemic evidence suggesting to John that the rest cure is failing. By representing the patient in this conflict rather than the overbearing physician, naturalism has an extra political edge that amplifies the danger of overwhelming medical consensus against the patient's own testimony.

\section{V: McTeague and Professionalization}

While the rest of this chapter concerns the standard medical profession, dentistry faced several challenges in the late $19^{\text {th }}$ Century as well. This political backdrop helped to fuel Frank Norris's 1899 novel McTeague. McTeague centers on its protagonist, McTeague, who practices dentistry in San Francisco after learning the trade from a charlatan. The novel is centered in melodrama as McTeague seeks to win the affection of Trina, who is the cousin and romantic interest of his best friend Marcus. After Marcus cedes any claim of Trina's affection to McTeague, the couple soon gets married. After Trina wins the lottery, Marcus finds himself embittered at what could have been, and after a confrontation with McTeague, he reports McTeague to the authorities for not having the proper state certification to practice. This moment begins the sharp decline McTeague faces; Trina is a hoarder who won't use any of her lottery winnings. The two suffer in abject poverty, where McTeague grows abusive, and he eventually murders her over the coins she withdrew from savings. The novel concludes as McTeague dramatically flees from the authorities and Marcus. The two have a stand-off in Death Valley, where they fight over the remaining water, and after McTeague murders Marcus, he is left to die there as he has no resources along with Marcus being handcuffed to him.

The political backdrop to this novel is significant, and the problem of professionalization has not been fully explored in the literary criticism. As aforementioned, the American Dental Association formed in 1859, and like the American Medical Association it made a practice of 
excluding any outsiders. In a 1909 book entitled The History of Dentistry, the authors make it clear what the profession expected of its practitioners: "What the dental profession desires, apart from the public protection, is to secure not only educated, skilled and trained, but respectable and honorable men in its ranks. In order to do this the public has to be taught that only such men are fitted to practice dentistry" (681). Many dentists who had practiced for only a few years lost their licensure through their various state governments; some states, like New Hampshire, did not agree with the majority, as New Hampshire made licensing practices illegal in 1889 (681). For the states who did enact licensing laws, a plethora of litigation arose as dentists whose licenses were stripped had the burden of proof to show their licenses should be deemed reputable (687). Nevertheless, this move toward professionalization did not have a tremendous effect on solving the problem since "the constituted guardians of the law have their time so much engrossed with greater offenders that dental misdemeanors are many times neglected because there is no time to look after them" (680). Illinois passed a law in 1905 allowing anyone who had practiced dental surgery for the past five years to continue unabated, and many other states followed in their stead.

Some scholarship on Norris has highlighted his longstanding interest in the professionalism theme even as there haven't been many studies about it in McTeague. David Heddendorf argues that Norris through his characterization of McTeague's ineptness "signifies not the dangers of professionalism but the threat of incompetence that professionalism wishes to exclude" (680). While this analysis is the opposite of Heddendorf's argument, he does note several important points. The fact that Norris went to Harvard to study writing under Lewis Gates suggests that Norris was aware of his status as "professional" writer, and Norris held strong opinions on the social responsibilities of said writers, as demonstrated in his essay "the 
Responsibilities of the Novelist." While Gates took a part in educating professional writing students, he felt alienated by an academy that grew toward specialized philologists and research scholars shortly after he taught Norris, and Heddendorf posits that Norris likely felt similar to Gates, who was committed to a life of intellectual inquiry but uncomfortable with the institutional context of that life" (685). Heddendorf also mentions that the professionalism theme arises in The Octopus when Dyke, a railroad engineer, is forced out of his career by an unfair cut in wages. He then becomes a highwayman and later uses his skills to hijack an engine. Heddendorf argues that the locomotive "assumes a shifting double value...representing the hope of personal satisfaction in a skill and the threat of systematic exclusion from practicing that skill” (684).

Furthermore, in a recent dissertation, Deirdre Dallas Hall asserted that Norris paints McTeague in an unflattering light based more off his belief in Anglo-Saxon superiority rather than his interests in professionalization. Nonetheless, her study compares McTeague to the reallife Dr. Laphame, a female abortionist arrested in San Francisco around the same time the novel was being written, to illustrate that due to the similarities in the case, Norris could have been far more critical of McTeague than not, and like this study, she asserts that as the novel progresses, Norris offers a larger critique of professionalization. She also illustrates that in his next novel, Blix, Norris interrogates the theme with a woman, Blix, who aspires to go to medical school, and he even paints her as a strikingly competent medical character (63); this ran contrary to the emerging professional codes of medicine that emphasized male practitioners.

While these essays highlight Norris's interests in professionalization, none take as hardline of a stance as this chapter in showing that Norris's characterization of McTeague as a competent professional outweighs McTeague's biological predispositions as a means of reading 
McTeague's character and as a means of defining the text's overall tone. The politics of professionalization is central to McTeague, as much of the plot depends on the crucial moment when McTeague loses his dental license for not having gone to a dental college after being reported to the authorities by Marcus. This study contends that Frank Norris, in his attempt to present a melodramatic, political tome, intentionally portrays McTeague as a competent dentist who, while not necessarily possessing the refined professional vocabulary of educated dentists, knows his profession and can treat patients with the proper standards of care. What is at stake in the novel is the exclusionary apparatus brought about by professionalization that excluded outsiders to protect this class's prestige. Through the narrator's attention to detail by incorporating the vocabulary from various dental textbooks, the text suggests that McTeague does not need to go to dental school to excel at his craft. The text also accents McTeague's marginalization with the symbol of the gold tooth, which is a form of cultural capital that signifies McTeague's ascension into the middle class. McTeague's subsequent downfall from grace starts with the selling of this tooth, stripping him of any chance of being part of the new Middle Class. While this argument would not go as far as to suggest that we should feel sympathy for McTeague's later actions, including the domestic violence and murder of Trina, it does suggest that in a naturalistic chain of pessimistic determinism, all of these tragedies transpired exactly as a result of marginalizing potential access to the Middle Class. The chain of naturalistic pessimistic determinism could be avoided in the novel, and perhaps in reality as well, only if new licensing laws would not have excluded McTeague. This argument posits that Norris's characterization of McTeague as a brute figure does not account for the novel's determinism as much as the socioeconomic factors leading to his downfall. The novel's critical 
political tone rests on this laurel; if only these newfound standards did not exist, McTeague and others like him could thrive.

From the opening pages of the novel, Frank Norris's narrator does not hesitate in providing details to depict McTeague's humble origins; Norris does this not to paint McTeague as an incompetent charlatan but rather to illustrate the extent of how far McTeague has come in overcoming his circumstances; in an America that remained divided by race and an America further divided by economic classes than ever, McTeague had already overcome nearlyimpossible obstacles. His father was a "hard-working shift-boss of the mine. Every other Sunday he became an irresponsible animal, a beast, a brute, crazy with alcohol" (5). Following his early death from alcoholism, Mrs. McTeague left her son with a travelling dentist, whom the narrator mentions was "more or less of a charlatan, but he fired Mrs. McTeague's ambition" (6). Regarding McTeague's dental education, the narrator notes that "he had learnt it after a fashion, mostly by watching the charlatan operate. He had read many of the necessary books, but he was too hopelessly stupid to get much benefit from them" (6). The narrator also begins his commentary on McTeague's Irish background, a background that has long been described by critics as a sort of biological determinism that shapes McTeague. He possesses an inner brute that the veneer of Middle Class civilization only covers: he is six feet three inches tall, can pull teeth with his bare hands, hands that have the look of an "old-time car-boy" (6). Furthermore, McTeague's general look suggests a "draught horse, immensely strong, stupid, docile, obedient."

At a first glance, these details might suggest a novel beginning what looks to be a classical interpretation of naturalism in that Norris creates in these passages a pessimistic determinism built on a sense of classism on the narrator's part. Indeed, Donald Pizer, one of naturalism's most prominent critics, describes this theme as "the source of [the novel's] violence 
beneath the surface placidity of life the presence in all men of animal qualities which have played a major role in man's evolutionary development but which are now frequently atavistic and destructive" (14). The narrator's intense focus on McTeague's hands in these passages have also been discussed by critic Kiara Kharpertian in an analysis of the novel's class discussion. Since McTeague later returns to his mining roots with the loss of his dental license, the narrative suggests that besides professionalization there's not a great difference between dentistry and mining (155). Structurally speaking, these details can prepare the reader for a pessimistic determinist outlook, but taken with other details illustrating McTeague's overall competence at his profession, it's more convincing to point out that the novel characterizes McTeague in this manner not to demean him but rather to show how, despite his origins, he manages to overcome these obstacles and succeed at his craft before professionalization, in its attempt to protect the legitimacy of the burgeoning Middle Class, excludes him based on a mere technicality.

Norris's narrator name drops a few books on dentistry that McTeague keeps in his parlor, books that Norris himself likely surveyed in writing McTeague, to illustrate their use as cultural capital more so than necessary knowledge needed to practice. On McTeague's bookshelf sets seven volumes of Allen's Practical Dentist along with The American System of Dentistry, the latter of which has passages to suggest that McTeague is perfectly competent at his profession despite having never read the book. The books are described as "ornaments" within McTeague's larger office, which has his tools, washstand, operating chair, and dental engine. He owns three chairs from the second-hand store, along with a steel engraving of the court of Lorenzo de' Medici, which "he had bought because there were a great many figures in it for the money", along with a stone pug dog and a thermometer" (7). The narrator describes these books along with all the other 'ornaments' in McTeague's office to illustrate his place within the new middle 
class. For McTeague, it is about as important to know the history of Lorenzo de' Medici as it is to read through these books for him to practice dentistry. While no textual evidence exists to suggest McTeague did read them, their description as ornaments suggests their use as mere decorations. As a form of cultural capital, the books serve as placeholders before his purchase of the gold tooth to showcase McTeague's successful graduation into being a skilled laborer. In an age of professionalization, where McTeague's diploma becomes a form of cultural capital required by the state, McTeague thus values the wrong kind of object.

Textual evidence suggests that McTeague is competent at his job as a skilled laborer with his hands. As McTeague operates on Miss Baker early in the novel, the narrator notes that McTeague "worked slowly, mechanically, turning the foil between his fingers with the manual dexterity that one sometimes sees in stupid persons. His head was quite empty of all thought, and he did not whistle over his work as another man might have done" (14). This passage implies that dentistry for McTeague is an act of manual labor, a sort of working with the hands. Kiara Kharpertian argues that McTeague's physical strength signifies to readers that "he is physically capable of the minuscule dexterity dentistry requires-labor that is multidimensional on an impressively small scale. His hands thus produce his successful career" (152). This point is well-taken, as the narrator signifies with the careful mention of McTeague's hands the potential for a new middle class of skilled laborers. Despite having the hands of "an old carboy", as mentioned earlier, McTeague handles his cases well and without complaint despite lacking the clinical knowledge necessary from the texts.

McTeague's first case with Trina goes against the best advice of one of the dental tomes on his shelf; the text does this to make a logical case for McTeague rather than to chastise him for his lack of theoretical knowledge. Upon looking at the tooth, McTeague diagnoses it as 
necrosis. Necrosis develops over a long period of time, and can develop with dental interference. The author of the textbook notes that "it is therefore, oftentimes a question in the diagnosis of such a tooth whether the great risk warrants meddling with it at all..."; it might be better to allow the tooth "to remain quiet rather than risk the more serious evil of acute pericementitis, alveolar abscess, and possibly, in a depraved habit of body, necrosis." In the text, McTeague acknowledges that he overthinks his case: "With most of his clients he would have contented himself with the extraction of the loose tooth and the roots of the broken one. Why should he risk his reputation in this case? He could not say why" (19). Nevertheless, McTeague invents an elaborate surgery to handle Trina's case:

It was the most difficult operation he had ever performed. He bungled it considerably, but in the end he succeeded passably well. He extracted the loose tooth with his bayonet forceps and prepared the roots of the broken one as if for filling, fitting into them a flattened piece of platinum wire to serve as a dowel. But this was only the beginning; altogether it was a fortnight's work. (19)

While the narrator notes McTeague's struggles in doing the surgery, he nevertheless notes that "he succeeded passably well" at undertaking the procedure. McTeague's reputation rests in his being able to work on his patients with a mechanical precision, so it is worthwhile to note he is able to extend his craft beyond his daily menial tasks. He also takes on a procedure not recommended by the dental textbooks of the time because of his personal interest in Trina and manages the procedure. While the narrator also describes the procedure with remarkable specific diction, understanding the process that went behind the procedure, it is not important that McTeague know this information as he possesses a sense of intuition with his hands. 
This passage has drawn some criticism from critic Laurence Scanlon, who interprets it as an inconsistency on Norris's part; however, this analysis disagrees in that structurally speaking, this moment makes the case for McTeague's technical competence. As the narrator mentioned, McTeague's case works out for Trina, who other than being taken aback by McTeague's invitation for a date after being under anesthesia (and also kissed by McTeague while under anasthesia, which admittedly damages McTeague's credibility as an ethical professional) comes out of the situation healthy. In his scathing critique of the novel in The Journal of The History of Dentistry, Lawrence Scanlon describes what he sees as an inconsistency on Norris's part: “he [Norris] knew only what he had read in and copied from a leading source...the result for McTeague is thoroughly bizarre, an allegedly stupid brute who works on teeth like a knowing, well-schooled professional" (20). Scanlon also asks: "How can McTeague be both a knowledgeable dentist and a stupid brute?" (19). Scanlon misses the point in that Norris likely did not make a mistake here, and the fact that McTeague came from humble origins also is beside the point in that despite his humble educational background, McTeague handles the case with exceptional care. For Norris, McTeague does not need the proper certification to work on his patient; merely possessing the dental tomes is enough for him, as he has already graduated into the profession.

McTeague's gold tooth is another important ornament; like his books, it's another signifier that illustrates his success as a professional. The fact that McTeague later loses his tooth due to the state closing his business further exacerbates the tragedy of his downfall along with the novel's representation of the disenfranchisement of the individual through professionalization. The narrator notes in the early pages that "it was his ambition, his dream, to have projecting from that corner window a huge gilded tooth, a molar with enormous prongs, 
something gorgeous and attractive. He would have it one day" (7). The importance of this tooth for McTeague is made apparent when comparing McTeague with his competitor who graduated from the college. The narrator describes him through McTeague's eyes as "a power, a rider of bicycles, a man about town, who wore astonishing waistcoats and bet money on greyhound coursing" (19). Later in the text, when McTeague gets married, he starts to dress nicer like the man about town dentist from the college, and the narrator states that "he began to observe the broader, larger interests of life, interests that affected him as an individual, but as a member of a class, a profession, or a political party. He read the papers, he subscribed to a dental magazine..." (109).

These passages all illustrate the overall importance of the class theme to the novel's structure, and the gold tooth is yet another ornament that gives the illusion of professional credibility. McTeague also subscribes to the dental magazines in these passages; subscribing does not mean he read them; the magazines give the illusion of respectability. McTeague manages to acquire all the cultural capital he needs to ascend to the middle-class except the most important one, the diploma. These passages all illustrate McTeague's natural American desire to climb the social ladder. These details all follow from McTeague's marriage to Trina, who helps to refine his manners; she also purchases the tooth for him as a status symbol. Hanging the gold tooth over his office showcases McTeague at his happiest moment as he thrives before he must cease practicing, and the text further builds on the tooth's symbolic significance by having the educated dentist drop by to offer McTeague thirty five dollars for the tooth, a significant sum by the standards of the late Nineteenth Century. The text's implicit argument suggests that McTeague has no reason not to belong within this profession; despite his humble origins, he manages to succeed and climb the social ladder. The fact that he belongs only exacerbates his 
downfall, resulting in another case where naturalism showcases the disenfranchisement of the individual at the hands of a larger social group.

The moment in the novel where McTeague loses the tooth provides the impetus for the rest of the text as larger social forces envelop McTeague since he has been forever excluded from a middle class where he can no longer produce his own labor; furthermore, this moment is a humiliating reminder of McTeague's lack of status without a diploma along with being a rhetorical argument against the standards of professionalization. Unlike the fancy hats and dental magazines, the gold tooth is the last remnant of McTeague's dental practice to be sold following the loss of his dental practice. The selling of the tooth also exacerbates the conflict between McTeague and Trina as she forces McTeague to sell his tooth rather than for her to withdraw enough money from her lottery savings to subsist.

The moment McTeague sells his gold tooth for five dollars is the pivotal moment of no return for him as he descends further into moral depravity following the loss of his class status The subscription to the dental magazines and wearing of fancy hats thus only serve as lesser capital for McTeague's larger commodity, which is why the Gold Tooth is one of the last items to be sold. The first moment between the two dentists following McTeague's loss of licensure is a terse one as McTeague refuses to exchange his tooth for the ample financial compensation of ten dollars. McTeague threatens physical harm to "the Other Dentist", who then taunting illustrates the truth behind the fantasy that the tooth represents: "You don't want to trade anything for a diploma, do you?" (155). Later in the text, when both the McTeagues start to sink under the weight of poverty, McTeague sells the tooth to the Other Dentist for five dollars, and he again emphasizes McTeague's lack: "Oh, Doctor—Mister McTeague, how do? How do?" (185). On the tooth, the Other Dentist buys it reluctantly because he knows that it does not 
signify class: "I prefer a little quiet signboard, nothing pretentious—just the name, and 'Dentist' after it. These big signs are vulgar" (186). The Other Dentist shows with these comments that McTeague fails to acquire the appropriate cultural capital, his diploma, and the comments add an extra layer in showing that McTeague, an unrefined brute, never practiced in good taste. It thus does not matter whether McTeague is competent or not; without that requisite diploma, he is prohibited from practicing. These passages all make a case against the exclusionary act of professionalization as the Other Dentist abuses his bargaining power; however, the Other Dentist also serves as a plot device to move the drama forward as his mere presence emerges at critical points anchoring the novel's plot. Before he sells the tooth, significantly after his first meeting with the Other Dentist, McTeague becomes abusive towards Trina as the weight of poverty sinks him. Following the loss of his class status by selling his meaningless signifier to the Other Dentist, McTeague kills Trina when she refuses to cede her lottery winnings, thus setting up the novel's final act. The plot is thus anchored in this character and the politics of professionalization, as McTeague, despite his lower-class origins, had succeeded in his profession and becomes a victim of unjust forces acting against him.

While much of the novel centers on how McTeague handles the loss of his license, examining the immediate aftermath of the moment highlights the novel's political stance against the politics of professionalization, and these arguments further implicate the state in the blame for McTeague's moral demise. It must be noted that McTeague lost his license only because Marcus reported him out of spite to the local authorities for not being licensed, so despite being in a burgeoning city and not a rural area on the scale of, let us say, Abraham Flexner's Kentucky, no one ever noticed that a charlatan practiced among the ranks; why notice, after all, considering a gold tooth hangs in a window? Following the immediate loss of licensure, McTeague and 
Trina provide arguments similar to the debates raging in the court systems. Trina argues, "They don't know how good of a dentist you are. What difference does a diploma make, if you're a first-class dentist?" (146). McTeague argues that his practical experience makes him a dentist when he quips, “Ain't I a dentist? Ain't I a doctor? Look at my sign, and the gold tooth you gave me. Why, I've been practicing nearly twelve years" (146). The text does not provide any sort of counterargument to these rhetorical questions Trina and McTeague pose. In a brief moment, they do consider fighting this ruling in court, but Trina, perhaps out of her own miserliness, argues to "not go near the law courts. I know them. The lawyers take all your money, and you lose your case. We're bad off as it is, without lawing about it" (156). These rhetorical questions anchor the text, reminding the reader that McTeague has unjustly been treated by professionalization, and as a disenfranchised individual, he does not have legal recourse since the greedy lawyers will only take his money. McTeague is characterized as a sympathetic figure in this instance, but these moments start McTeague's subsequent downfall.

Unlike some previous work done on the professionalization subplot, this analysis argues that Norris takes away McTeague's licensure, despite some exceptions being made in several statutes, to nevertheless argue against professionalization, and the aforementioned rhetorical questions from McTeague and Trina echo similar arguments made in the public sphere. Like this work, Lawrence Scanlon acknowledges McTeague's loss of licensure as the novel's pivotal moment, and he compares that moment to Aristotle's Poetics where Aristotle had discussed the idea of peripeteia, the reversal of fortune (22). However, Scanlon notes that most states included a grandfather clause into professionalization laws, meaning that any practicing dentists, usually having practiced for at least five years, could remain if they registered with the state board, and California, in 1885, was among the states that passed these laws. Scanlon, despite his 
excellent historical research, persists in arguing Norris's stupidity, arguing that "Norris acted in an unintelligent and careless manner in not tracking down the actual law that in the real world underlies the pivotal event in his fictional world of McTeague" (22). Scanlon misses the point in several ways. While the professionalization subplot is the novel's pivotal moment, the novel asks readers to think beyond mere dentistry to other professions as well; as seen in Dent $v$ West Virginia, grandfather clauses rarely existed in standard medical practice. Furthermore, unlike a realist novel that is supposed to mirror reality, McTeague does not try to remain objective. Norris was a careful novelist, as many have argued, so the fact that McTeague probably would not lose his license in California is beside the point in that Norris's main objective, as was the same with several other naturalists, was to document the ill effects Progressive policies could have on everyday people.

The novel's opening pages paint Marcus as a primary antagonist to further anchor the novel in the politics of Progressive professionalization. The novel characterizes Marcus as a Progressive politician with a sense of populism; however, it paints Marcus's rhetoric as empty words, and the text does not hesitate in showing that Marcus only acts out of spite by reporting McTeague. The narrator notes that "Marcus had picked up a few half-truths of political economy - it was impossible to say where" and performs his politics with empty words and gestures:

He was continually making use of the stock phrases of the professional politician — phrases he had caught at some of the ward "rallies" and "ratification meetings." These rolled off his tongue with incredible emphasis, appearing at every turn of his conversation—“'Outraged constituencies," "cause of labor," 


$$
\begin{aligned}
& \text { "wage earners," "opinions biased by personal interests," "eyes blinded by party } \\
& \text { prejudice.” McTeague listened to him, awe-struck. (12) }
\end{aligned}
$$

These passages would resonate with a national audience in the 1890 s as readers would put two and two together with the buzz words the narrator puts in quotes with Progressive populist politicians who, through professionalization, sought to protect middle and lower class interests against unrestrained capitalism. Marcus further exaggerates his complaints against capitalism immediately following this description: "It's the capitalists that's ruining the cause of labor...white-livered drones, traitors, with their livers white as snow, eatun the bread of widows and orphuns; that's where the evil lies" (12). Marcus is obviously a Progressive; subsequent events in the novel illustrate the text's attitudes regarding Progressives as charlatans.

Unlike McTeague in his professional practice, the text argues that Marcus is a charlatan not only in his political beliefs but also in his professional practice, and this in turn adds another layer of complexity suggesting that Marcus is a hypocrite for reporting McTeague for not having licensure when he too lacked one. By the time the novel was published, the veterinary profession sprang up into the American Veterinary Medical Association, and several colleges nationwide had adopted veterinary programs (avma.org). Marcus, however, serves as an apprentice under Grannis. Before the passage illustrating Marcus's rhetoric, the text shows the types of causes Marcus takes with his rage against awkward bicyclists: "Ain't I got a right to cross a street even, I'd like to know, without being run down-what? I say it's outrageous. I'd a knifed him in another minute. It was an outrage. I say it was an outrage" (10). This passage highlights the absurdity of Marcus's politics; Marcus acts takes up ridiculous causes acting in his own self-interest. This brief description prepares the reader for Marcus's later betrayal of McTeague by reporting his lack of a dental diploma since Marcus felt cheated at ceding Trina, 
who just afterward won the lottery, to McTeague in their love triangle. Furthermore, the text also paints Marcus as a charlatan in his work as a veterinarian and juxtaposes him with Old Grannis, his mentor:

He [Grannis] was an Englishman and an expert dog surgeon, but Marcus Schouler was a bungler in the profession. His father had been a veterinary surgeon who had kept a livery stable near by, on California Street, and Marcus's knowledge of the diseases of domestic animals had been picke dup in a haphazard way, much after the manner of McTeague's education. Somehow he managed to impress Old Grannis, a gentle, simple-minded old man, with a sense of his fitness, bewildering him with a torrent of empty phrases that he delivered with fierce gestures and with a manner of the greatest conviction. (11)

The narrator's comparison of Marcus with McTeague is significant in that despite McTeague's humble origins and lack of eloquence, compared with Marcus, full of empty rhetoric, McTeague's mechanical precision and lack of sophisticated diction is preferable in comparison. It must also be noted that nowhere in the text does the narrator explicitly indict McTeague for a lack of competence as happens with Marcus here. The mention of Marcus's incompetence in the field of veterinary medicine also extends the novel's commentary on professionalization to veterinary medicine; in turn, this suggests that the novel's commentary is not only about dentists but the move toward standardizing all middle-class professions in the late Nineteenth Century. Marcus's anonymous complaint reporting McTeague to the state authorities also makes McTeague's disenfranchisement all the more unfair, further adding to the text's representation of the disenfranchised individual. 
The latter half of the text remains anchored in the logic of professionalization from the novel's first half in subtle ways; namely, McTeague's moral downfall stems from no longer producing his own labor. Even though McTeague loses his dental license, the narrator refers to him as "the dentist" throughout the rest of the text; the text does this to refer to McTeague's lost signifier that nonetheless remains part of his identity. Furthermore, the narrator compares McTeague's mining work that he returns to with dentistry in a passage near the text's conclusion: "in the Burly mill he saw a queer counterpart of his old-time dental engine...It was the same work he had so often performed in his 'Parlors,' only magnified, made monstrous, distorted, and grotesqued, the caricature of dentistry" (213). Kiara Kharpertian reads this passage as the text's commentary on how "this moment shines a more negative light on dentistry. McTeague's dental skill looks to be little more than a chance outgrowth of his working class, manual mining...McTeague can fix the teeth of the middle class, but never again can he cross into the bourgeoise" (155). This analysis concurs with this reading except for the assertion concerning dentistry's negative depiction. The text depicts McTeague as competent in the first half as he overcame his natural caste and emerged into the middle class. This passage, combined with the rest of the text's attitude toward professionalization, suggests a melancholy reading, as McTeague now exists in this situation solely because of overbearing state standards. McTeague's return to mining also suggests a sort of reverse class stratification; the text argues by forcing McTeague back into mining from dentistry that middle class professionalization makes it impossible for Americans to improve themselves.

\section{VI: The Victims of Medical Professionalization in Steinbeck Fiction}

By the time Steinbeck started writing in the 1930s, the Progressive era move toward professionalization had largely succeeded as most professions, medicine not excluded, had 
adopted standards and criteria for entry. As was the case with many writers from the 1890s, writers in the 1920s and 30s found themselves succeeding at writing as a profession as well. This argument suggests that John Steinbeck, a Renaissance man of sorts who embraced a holistic ecological and ethical worldview in conjunction with his biologist friend Ed Ricketts during the 1930s, not only found professionalization to be limiting in the narrowness of its epistemological scope but also viewed it as a potential danger to interested outsiders who wanted to enter the middle class. Following Steinbeck's success in representing the Joad family as victims of systematic capitalism in The Grapes of Wrath, Steinbeck found a new point of interest in representing victims of professionalization. We can trace this theme developing across a large body of Steinbeck's fiction from the mid-1930s to the mid-1940s as Steinbeck lightly touches on the subject until he represents professionals as antagonists in some of the later works.

Steinbeck's association with naturalism has long been a point of contention among Steinbeck scholars; notably, this contribution has asked to what extent Steinbeck differs from the writers of the 1890s with the culmination of many of those concerns, including the limitations of unrestrained capitalism, in the 1930s. It is widely known that Steinbeck developed interests in science and philosophy as he and a like-minded group of California intellectuals gathered together to discuss ideas, which most notably included the marine biologist Ed Ricketts. ${ }^{3}$ In addition to these interests, Steinbeck shared an actual interest in Darwin rather than the social Darwinism that impacted the fiction of the 1890s; this gave Steinbeck's work a naturalist undertone that is similar to yet contrasts with earlier literary naturalism. Steinbeck's biographer, Jackson Benson, describes both similarities and differences to the naturalists of the late nineteenth century. Like Crane and Twain, Steinbeck shows man as a small speck in an indifferent universe. Like Sinclair and Norris, Steinbeck's characters are victimized by social 
Darwinism, subject to harsh laws of nature as in Jack London's work, or are controlled by the physical-chemical scheme of a mechanical universe. Unlike these writers, Steinbeck "reacted to science in a positive way, embraced a scientific perception of the universe with enthusiasm, and really knew something about science" (244). Benson further argues of their differences:

the fiction of such writers as Crane, Norris, and Dreiser often suggests that the dream is better than the reality, but the dream is impossible to hold on to. Steinbeck's more thoroughly non-teleological perception leads to a fiction in which things simply are as they are. The real bitterness lies in man's attempts to divorce himself from nature and in his attempts to conceal or avoid reality. (24344)

While Benson does well to comment on the metaphysical themes of naturalism, notably how well Steinbeck handles free will versus determinism in a Darwinist universe, he does not tie in Steinbeck with the political inclinations of naturalism even though Steinbeck gradually developed a harsher rhetorical tone throughout the 1930s. This contribution ties in Steinbeck's political thought with the aesthetic discussions of naturalism, a genre whose form is closely associated with its politics.

Like with the other naturalists, Steinbeck's work has suffered in the critical canon in some part because of its political emphasis rather than aesthetic innovation. In his introduction to an edited collection of essays on The Grapes of Wrath, Harold Bloom chastises Steinbeck for his failures in style and his lack of ambiguity: "If Steinbeck is not an original or even an adequate stylist, if he lacks skill in plot, and power in the mimesis of character, what then remains in his work, except its fairly constant popularity with an intense number of liberal middlebrows, both in his own country and abroad?" Bloom also goes on to describe Steinbeck 
as a failed disciple of Emerson whose attempts to fall into the American sublime devolve into bathos in everything he wrote, including Of Mice and Men and The Grapes of Wrath. With The Grapes of Wrath, Bloom at least leaves the question of Steinbeck's significance to the reader's interpretation: "compassionate narrative that addresses itself so directly to the social questions of its era is simply too substantial a human achievement to be dismissed. Whether a human strength...is also an aesthetic value... is one of those larger issues that literary criticism scarcely knows how to decide." However one might feel about Bloom's comments, the significance of his critiques to Steinbeck's legacy cannot be overstated; however, this project demonstrates the fact that naturalism's political tendencies is an aesthetic innovation in itself in emboldening a populist politics of resistance against the professionals who solidified their roles at the expense of outsiders who found entry into the middle class inaccessible.

Throughout the 1930s and 1940s, Steinbeck in conjunction with Ed Ricketts and others developed an epistemological distinction between what they coined as "teleological" versus "non-teleological" thinking. While this became an ontological way of thinking about environmental concerns in The Sea of Cortez, this philosophy's origins can be traced in the way Steinbeck characterizes professional figures in his fiction leading up to The Sea of Cortez. In that text, Steinbeck defines teleological thinking as a type that: considers changes and cures - what 'should be' in the terms of an end pattern (which is often a subjective or an anthropomorphic projection); it presumes the bettering of conditions, often, unfortunately, without achieving more than at most a superficial understanding of those conditions. In their sometimes intolerant refusal to face facts as they are, teleological notions may substitute a fierce but ineffectual attempt to change conditions which are assumed to be undesirable, in 
place of the understanding-acceptance which would pave the way for a more sensible attempt at any change which still might be indicated. (861)

In contrast, Steinbeck defines non-teleological thinking as the better alternative: "it concerns itself primarily not with what should be, or could be, or might be, but rather with what actually 'is' - attempting at most to answer the already sufficiently difficult questions what or how instead of why" (862). Steinbeck provides a medical example in this chapter as he discusses in more detail the limitations of teleological thinking:

Grant for a moment that among students of endocrinology a school of thought might arise, centering upon some belief as to etiology — upon the belief, for instance, that all abnormal growth is caused by glandular imbalance. Such a clique, becoming formalized and powerful, would tend, by scorn and opposition, to wither any contrary view which, if untrammeled, might discover a clue to some opposing 'causative' factor of equal medical importance. (869)

This example from The Log illustrates a teleological medical example of the limitations of professional guilds in medicine. The endocrinology sect, because of its power and sheer influence, would have a difficult time accepting any contrary view because it might damage their livelihoods to consider it. While Steinbeck also associates teleological thinking with religious fundamentalism, it is also important to see that he applies its limitations to professional guilds. In addition to his ontological definitions, Steinbeck's views toward the limitations of professionalization can be seen through his own experiences as well. Beyond talking philosophy with a group of like-minded intellectuals, Steinbeck, who was affected by the injustices and prejudices imposed on migrant workers, found his writing growing more political as he transitioned from In Dubious Battle, a more apolitical portrait of the migrant worker issue, to The 
Grapes of Wrath, a work that as aforementioned has been criticized for being overly political. It's worth noting that as Steinbeck volunteered during the migrant worker immigration crisis, he took special offense, as Jackson Benson has documented, to the way public health nurses discriminated against the workers (453). Furthermore, even following The Grapes of Wrath, Steinbeck maintained an interest in alternative, more holistic approaches to medicine. In his essay on East of Eden, Robert DeMott, following his biographical work detailing Steinbeck's Reading, documented the effect Dr. Gunn's Family Medicine, a nineteenth century homeopathic tract, had on the text as it even appears there. DeMott mentions that Steinbeck's grandfather had the book in his personal collection; therefore, Steinbeck likely appreciated the book's similarities to his own worldview (58).

The third section of this chapter illustrates how Steinbeck's thinking did not develop in a vacuum as he was interested in the theme throughout the decade, and as the decade progressed and as his opinions grew more pronounced, Steinbeck's fiction took a more political turn. We see the origins of the theme in "The Snake," an early short story documenting a scientist's lack of empathy and care to a nonhuman patient. As Steinbeck grew more alienated from professionals during the writing of The Grapes of Wrath, we see his humanitarian arguments against them arise there with his lamentations against the Farmers' Association and the police as a force that protects professional interests. The Pearl, while often read as a simple allegory, also examines the greed and self-interest of a medical professional only out to protect his own interests even at the expense of his patient. Finally, in his screenplay The Forgotten Village, Steinbeck documents the teleological thinking of two self-interested parties, a professional mystic whose profession calls for a rejection of science, along with the medical community, whose own self-interests do not co-align with a few patients in the remote countryside who 
might need their help. Through his engagement with this theme, we witness Steinbeck's progression not only towards a more political but also a more pessimistic determinist, even documentary aesthetic as seen with other naturalists like London and Dreiser.

Steinbeck's early short story “The Snake” features a scientific persona, Dr. Phillips, who is likely a fictional stand-in for Ed Ricketts, as both the character and man are biologists who run a laboratory. Neither the fictional Dr. Phillips nor his real-life stand in, Ed Ricketts, practiced medicine on people professionally; however, Steinbeck brings to attention the politics of professionalization as Dr. Phillips oversees a wide variety of nonhuman life for which he is ethically responsible. While Steinbeck later constructed Ricketts as the beloved "Doc" in Cannery Row and Sweet Thursday, the characterization of Dr. Phillips here is not flattering in that the text calls attention to the scientist's professional ethics along with $\mathrm{h}$ is limited teleological thinking in how he treats the nonhuman animals in his laboratory. The plot revolves around Dr. Phillips running his laboratory on a normal day, and he is interrupted in his work by an unnamed woman who wants to first buy a snake and then settles for watching it eat a rat. Upon the act of watching the snake, the woman "relaxes, relaxes sleepily" and then in watching the snake unhinge its jaws to eat the rat entirely, Phillips finds himself afraid to watch the woman, unsettled at her actions. Most of the critical attention that has been paid to this story involves the story's mythic implications; Joseph Fontenrose argues that the laboratory is a "zoological garden of Eden" intruded upon by a "neurotic female" devil"; Reloy Garcia argues that the woman introduces the principle of evil into the scientist's world, and Bernard Mandelbaum even contended that the story was but a dream of Dr. Phillips (qtd in Hughes 4041). ${ }^{4}$ When asked why he wrote the story, Steinbeck famously gave what Jackson Benson refers 
to as a Robert Frost answer: "it meant just what it said—it was just something that happened and he (Steinbeck) didn't know any more than anyone else what its implications might be" (290).

Despite Steinbeck's appeals to ambiguity, his text calls on the reader to question Dr. Phillips's ethics by calling to attention his lack of moral reflection toward his professional life. This argument disagrees with Fontenrose in that the woman who visits Dr. Phillips is not a female devil figure insomuch as she represents a mirror for Dr. Phillips to realize the limitations of his teleological worldview. Phillips recognizes the limitations of his own teleological thinking by seeing his worldview reflected back upon him in the woman's cold stare, and the pleasures she takes in watching the snake eat the rat disturbs Phillips in part because of his own numbness to these acts due to his coda as a professional scientist. The story begins with Phillips running his laboratory on an ordinary day. Like Fontenrose's Eden analysis, Phillips appears content with himself and happy with his work despite some of the larger consequences of what he is doing. For the sake of scientific research (the purpose of which the narrator does not specify), Phillips gasses a cat to death. As the woman walks into the lab, she looked "without expression at the cat's open throat," in turn she "made him nervous" (51). From the onset, this moment illustrates to Phillips the ramifications of his objective worldview; as just like him, she looks without expression at the test subject. Phillips is more concerned with the result of the work rather than the consequences to the animals for whom he is ethically responsible. Phillips is startled as he finds within the woman his own reflection.

Upon asking Phillips if she could feed a snake in his laboratory, Phillips becomes creeped out and immediately contemplates the ontological ramifications of this actions. He remarks that “it's better than a bullfight if you look at it one way, and it's simply a snake eating his dinner if you look at it another"; the narrator then remarks of Phillips that "he could kill a thousand 
animals for knowledge, but not an insect for pleasure. He'd been over this in his mind before" (53). The woman, however, insists that he feed the snake, and as the snake begins to eat the rat, the narrator notes that Dr. Phillips "found that he was avoiding the dark eyes that didn't seem to look at anything" (54). Dr. Phillips then turns the subject to dreams: "lots of people have dreams about the terror of snakes making the kill. I think because it is a subjective rat. The person is the rat. Once you see it the whole matter is objective. The rat is only a rat and the terror is removed" (54). Dr. Phillips finds, however, that the terror is not removed, as he cannot bear to look at the woman as she watches the snake, fearing that he'll be sick if she opens her mouth when the snake unhinges its jaws (56).

While Dr. Phillips tells himself that he murders the nonhuman test subjects for knowledge rather than pleasure, the woman forces him to think about the consequences of his profession, a marine naturalist, for taking lives without plausible explanation. Although Phillips notes that when applying reason to a terrifying dream, the dream fades, he finds the cold, empirical reason of his profession in the eyes of the woman. Phillips cannot look at her because he finds he takes the same pleasure in his work as she takes in watching the snake devour the rat. At the same time, her fascination stems from asking non-teleological questions, what or how, instead of why, so he finds the limitations of his own ontology in her more all-encompassing gaze as well. In this text, Steinbeck thus draws to attention the disenfranchisement of the individual at the hands of professions. It should be reasoned that this rat, helpless against what is coming from the snake, can be compared with human patients helpless against the overwhelming authority of the medical profession. In this newfound era of laboratory science, patients are little more than rats in Dr. Phillips's laboratory. 
With the victory of professionalism in the early decades of the twentieth century, Steinbeck thus interrogates the notion of whether being a trained professional scientist can offer a holistic perspective on everything science affects. Despite having personal qualities in common with Ricketts, and despite the fact that this story originated from a personal anecdote Ricketts gave, Dr. Phillips is characterized as an antithesis to other fictional depictions of Ricketts in works like Cannery Row and Sweet Thursday, a scientist whose teleological perspective is reflected back on him by the woman. In his last words after the woman's exit, Dr. Phillips mutters, "Maybe I'm too much alone. Maybe I should kill the snake. If I knew—no, I can't pray to anything" (57). What terrifies Dr. Phillips is thus not the snake-like woman, but the fact that he can no longer subscribe to his own worldview. Steinbeck's parable calls to attention the ethical quandaries of contemporary medicine, and this gives what appears to be an apolitical story a politicized subtext and tone.

The Grapes of Wrath was the end result of Steinbeck's long engagement with the California migrant labor problem. While the novel mostly captures the shift to industrial agriculture from Jeffersonian small farmers, the process of writing the novel helped to shift Steinbeck's thinking to the same sort of polemical naturalism as Norris and Gilman. The novel certainly ended Steinbeck's long engagement with the tensions surrounding the California migrant labor issue, as Steinbeck started with the more politically neutral In Dubious Battle that showed the futility of both sides of the struggle followed by his revered novella Of Mice and Men to culminating in The Grapes of Wrath.

While The Grapes of Wrath isn't pertinent to medical professionalization debates, Steinbeck's experiences while composing it led to some of his harsher depictions of medical professionals in the fiction following his famous novel, Tom Collins played an integral role in 
helping Steinbeck to fully develop his thinking on the shortcomings of medical professionalization on the patient, a theme he would resolve after The Grapes of Wrath. Collins, supervising over the New Deal migrant worker camps in California, was not a medical practitioner, but he did preside over the general public health concerns. As Jackson Benson notes, Collins had methods similar in nature to the $19^{\text {th }}$ century alternative practitioners practicing empiricist medicine, as he collected numerous data in his reports, from the occupiers of campers, to the cars they drove, to visitors, work opportunities, attitudes of nearby farmers, the conditions in local squatters' camps, and even the diets of the farmers from personal observation (343). Benson goes on to note that Collins "had a great faith in a kind of basic Jacksonian democracy, which he felt was not only the natural preference of the migrants but also the natural condition toward which all men aspired" (343). While Collins supervised over these camps, his approach differed greatly from the public health officials at the state level, as Steinbeck had long felt disgusted with some of their prejudices against the migrant workers (453). Collins, in combining his basic beliefs in Jacksonian democracy with a sense of New Deal advocacy, played a significant part in Steinbeck resolving his thoughts on medical practitioners even once Steinbeck finished the Grapes of Wrath.

Following the Grapes of Wrath, Steinbeck's novella The Pearl calls attention to the shortcomings of professional medical practitioners. For a work as widely read as The Pearl, little scholarly attention has been paid to its political subtext. ${ }^{5}$ Like "The Snake," which illustrates Dr. Phillips's teleological worldview, The Pearl follows a doctor whose narrowminded thinking and quest for financial gain almost causes the death of his patient, Kino's child Coyotito. Following off the heels of Steinbeck's "Sea of Cortez" voyage and his labor novels, Steinbeck represents the injustices suffered by the poor natives of Mexico. Although 
they both live impoverished lives, both Kino and Juana start the novella content on a normal day until they both find themselves at the mercy of the town doctor when their young son is bitten by a scorpion. The first time we meet the doctor is when he proclaims: "Has he any money? No, they never have any money. I, alone in the world am supposed to work for nothing — and I am tired of it." (242). From the beginning of this novella, the doctor sets a pessimistic determinist plot in motion with social forces conspiring to destroy Kino's family. Kino's inability to pay the doctor causes him to seek the pearl that ultimately causes his fall from the paradise he inhabits as he finds himself now at the mercy of the market. Beyond the social determinist angle, Steinbeck also sets The Pearl up to be a rhetorical argument against professionalization. The doctor in his quest for financial gain fails to remember the Hippocratic oath and asks rhetorical questions asking for sympathy. The text suggests that none should be given.

The omniscient narrative voice questions both the wisdom of the doctor and calls attention to his greed as Juana treats her baby just after she is denied treatment in Chapter II. She gathers brown seaweed, makes a poultice of it, and applies it to the baby's shoulder at the bite, which the narrator says is "probably better than the doctor could have done. But the remedy lacked his authority because it was simple and didn't cost anything... She had not prayed directly for the recovery of the baby — she had prayed that they might find a pearl with which to hire the doctor to cure the baby, for the minds of people are as unsubstantial as the mirage of the Gulf" (245). The narrative voice here criticizes the notion of the doctor's cultural capital. Considering Steinbeck leaves no evidence to suggest that the doctor is a quack, his remedy has more authority, whether it works better or not, in a society ruled by professionalization. The narrator also suggests that these practitioners with elite knowledge can commit these injustices because of their cultural capital; unlike the common-sense treatments, their society emphasizes knowledge, 
and people without the means of accessing it have no democratic voices in their treatment.

Steinbeck thus calls into question the power dynamics between the poor and the rich in countries with widespread illiteracy, showing in turn that elite guilds have the potential to prey on the people who merely accept the professional authority they exert.

The last time we see the doctor in the novella is midway through it immediately after Kino finds the pearl. Gossip spreads over the town that Kino had found the pearl of the worldthe most valuable and beauty pearl around — when the doctor decides to pay the family a visit. Kino grows suspicious of a white powdery substance - ammonia - and a capsule of gelatin that the doctor fills with the ammonia. While the narrator does not directly suggest the effectiveness of this treatment, the voice does mention Kino's suspicion: "he could not take his eyes from the doctor's open bag, and from the bottle of white powder there. Gradually the spasms subsided and the baby relaxed under the doctor's hands. And then Coyoyito sighed deeply and went to sleep, for he was very tired with vomiting" (262). The doctor's immediate explanation for treating Coyoyito for his scorpion bite also suggests he cons Kino: "Sometimes, my friend, the scorpion sting has a curious effect. There will be apparent improvement, and then without warning-pouf!"” (258). The narrator then notes: "He pursed his lips and made a little explosion to show how quick it could be, and he shifted his small black doctor's bag about so that the light of the lamp fell upon it, for he knew that Kino's race love the tools of any craft and trust them" (258). After his first visit, the narrator also states: "Everyone knew why the doctor had come. He was not good at dissembling and he was very well understood" (260). On his second visit, the doctor asks, "When do you think you can pay this bill" and the narrator then states: "He said it even kindly" (262). Kino's relatives tell him that Kino has found a pearl, and the doctor offers to store it in his safe for him. The doctor not only gives the baby a treatment that makes him 
worse, but his function in the text's design is to set in motion a fear in Kino that someone will rob him of the pearl, a fear that drives Kino to his death by the novella's end. Compared to earlier depictions of professionalization that offered more in the way of ambiguity, Steinbeck by the early 1940s had more of a hardline stance on the issue, and not coincidentally as a result, his experiences with professionals who excluded people from entering their inaccessible middle class resulted in more political narratives that took up a pessimistic determinist stance. In yet another work of literary naturalism, we thus see another individual family disenfranchised by the elite protections offered to the professional authority.

Almost at the same time as he composed The Pearl in the early 1940s, Steinbeck, following his experiences with the migrant workers, developed a screenplay documenting the rise of modern medicine in Mexico called The Forgotten Village. This documentary is the culmination of Steinbeck's full transformation to polemical naturalism. Like other writers with naturalist sensibilities, Steinbeck found his previous work, including the Grapes of Wrath, influenced by a documentary style. As writers like Norris and Dreiser likely had some influence from works like Jacob Riis's How the Other Half Lives, Steinbeck found himself intrigued by the documentaries of New Deal filmmaker Pare Lorentz, whose work The Plow that Broke the Plains mixed not only documented the effects of the Dust Bowl on the migrant workers but also had a sense of advocacy for changing the situation. The same sense of political advocacy applies to this film, as Steinbeck documents the lack of medical professionalization in Mexico and the villagers' gradual acceptance of professionals. While almost little scholarly attention has been paid to this screenplay, as most Steinbeck scholars gloss over this screenplay as a transitional work, most take the script at face value as Steinbeck documents the ill effects of the villagers' teleological thinking in amplifying the deteriorating health of the child patient. Taking 
Steinbeck's earlier concerns about medical professionalization into consideration, it must be noted that while Steinbeck does show modern medicine working, it acts as an impersonal force, a force that does not value the patient, further continuing Steinbeck's critique of professionalism.

The text of The Forgotten Village is irregular in that it's not written as most screenplays are but rather as short descriptions of scenes accompanied by captions from the film's narrator. Steinbeck notes in the introduction to the screenplay some shortcomings: sound could not be recorded for technical shortcomings, the dialogue couldn't be recorded even in Spanish because the natives used the Indian language of their ancestors, so he adapted "the method of the old story-teller-a voice that which interpolated dialogue without trying to imitate it, a very quiet voice to carry the story only when the picture and the music could not carry it, and above all, a spoken story so natural and unobtrusive that an audience would not even be conscious of it" (6). While Steinbeck proclaims impartiality, the actual story in The Forgotten Village has a political tone as the narrative follows a boy, Juan Diego, who following the death of his brother to illness, now acts to try to save his newborn sister. What happens thereafter is a tale of Enlightenment as Juan Diego realizes education and a non-teleological worldview are key to overcoming this predicament.

It is tempting to read the text at face value in reading this narrative as a tale of enlightenment as the young boy helps to bring modern medicine to the village. In what might remind readers of ethnocentric approaches to Natives in colonial American letters, it is frustrating to see the wise woman, Trini, refuse to acknowledge the new advancements mainly for selfish reasons. A local teacher explains to the villagers that invisible pathogens cause diseases like typhoid, smallpox, and malaria, yet he fails to get the villagers to realize ways they can improve the public health: "We must clean up the water and cure the children. The serum 
from an infected horse can cure the children" to which the town chief replies, "Horses' blood! Are we animals? Are we horses or dogs or rats? What is this horses' blood? What is this new nonsense?" (86-87). Following the return of Juan Diego with medicine, the narrator notes that "Trini saw them and was afraid for her business. The horse-blood men are here" (108). The local townspeople think of medicine in mystical terms, and it takes a brave innovator like Juan Diego to get them to see a scientific perspective. Written for a culture already having achieved Enlightenment, the text naturally urges its readers to sympathize with Juan and to look disparagingly on the natives whose limited worldviews exacerbate the tragedy happening to children dying of pathogens.

On the other hand, the text also calls for a sense of skepticism at the indifferent medical profession that is supposed to save the villagers, and it also calls to attention that Trina's rituals at least have a patient-centered approach that helps to build a sense of community. With a portrait of Juan Diego walking alone in the Mexican wilderness, an image that might remind readers of similar imagery in other naturalist texts featuring an indifferent nature, the narrative voice proclaims: “Then Juan Diego, who had never been more than ten miles from his own village, went out into a strange new world, among people he did not know. He was frightened, but he had to do it" (95). Upon arriving in the distant city where medical officials are, the image shows five power lines back to back, with the caption: "the city was terrible to him" (101). When Juan Diego reaches the hospital, the doctor tells him: "the medical trucks are all out. There is no one to send" (105). After some pleading from Juan Diego, the doctor sends a rural service car with an intern and a nurse, along with equipment for water-tests, and serums (106). Upon arriving back at the village, Steinbeck calls the intern a doctor, whom the villagers quickly drive out of town with curses seeing how his serum is full of horse blood. 
These little details all posit a sense of skepticism in the narrative about the acceptance of professional medicine into the village. While the narrative nonetheless ends on the intern giving Juan Diego a speech about how he can be a force for change in a society rooted in mysticism, it is significant that Steinbeck makes the savior of the village an aspiring professional rather than one already rooted into the professional system. If Steinbeck wanted to tell a complete narrative of Enlightenment in a land rooted in mysticism, he could have easily had a physician come to the town rather than an intern; this exacerbates the tensions he has had with medical professionals in his previous works, especially The Pearl. Furthermore, the narrative voice's focus on the distance between the rural town and the distant city also accents a distance between the medical professionals at the hospital and the patients who need their care. Despite undoubtedly assisting the patients in the city hospital, the doctors are both physically and metaphorically removed from the patients who could use their assistance. Despite this story being written about the rise of professional medicine in Mexico, Steinbeck's own disapproval of the way medical authorities treated the migrant workers in California likely led to the narrative's focus on the intense distance between the medical establishment of the city and the villagers who need their help. Like with previous works like The Grapes of Wrath with Tom Joad being an example for others who deal with class conflict, Juan Diego's heroism rests in large part because of his ability to maintain his strong moral character despite existing in a world where indifferent social forces act against him. In Steinbeck's naturalism, it is not the professionals who help the villagers overcome their own teleological thinking but rather the strong moral conviction of his characters.

\section{VII: Concluding Thoughts}

This chapter has built off the foundations of both genre scholarship and political scholarship on naturalism to argue that these selected texts showcase the powerlessness of 
individuals against the social validity of a unified profession. Both Gilman and Steinbeck illustrate the lack of agency of patients in a system prioritizing clinical knowledge and expertise over human empathy and understanding the basic needs of patients. Gilman offers the unique perspective of providing the patient's point of view, a case that did not happen in the gothic texts examined in Chapter 1 as characters like Georgiana were passive victims. Steinbeck offers a third-person narrator just as Hawthorne did to illustrate the injustices committed by professionalization, though his work tonally is much more severe in representing how the profession protects its members even at the expense of patients. Norris's narrator remains aloof, like the documentary nature of writing like Jacob Riis's How the Other Half Lives, but the narrator nonetheless provides several clues to suggest that McTeague is a competent dentist, and his gradual decline after losing his license comments on the exclusionary nature of professionalization in closing off entry into the middle class.

It is significant that all of these works showcase elements of melodrama from gothic fiction: Gilman's narrator descends into madness at the hands of an overbearing physician, McTeague becomes a domestic melodrama between McTeague, Trina, and Marcus after the loss of his license,, and Steinbeck's fiction goes to great length to prioritize the lack of agency patients have against those with professional authority. With these similarities, we see that naturalism evolved out of the antebellum romances popular in the latter half of the century and shares more in common with the gothic than realism in both form and function.

Even more than the influence of the significance of gothic tropes to naturalism, we see that the naturalist form separates itself from its forbearers with its sharp political tone. The difference between the gothic and naturalism can be difficult to distinguish, but even more than common themes and tropes, we see that naturalism leans toward taking a sympathetic stance for 
patients, whereas the gothic represented the alarming possibilities of the extremes of both professionalization and deregulation of the profession. Naturalism at its core represents the interests of the common people, and its overbearing pessimism and determinism is a means of advocating for change. Crane's Maggie: A Girl on the Streets documents negative social conditions in the city; Dreiser's Sister Carrie sharply critiques the rise of consumer culture; Steinbeck's The Grapes of Wrath ardently illustrates the injustices committed by banks and professional farmers on common people hoping to improve themselves. Unlike the literary elites of realism like Howells and James, naturalism maintained an inherent populism, and its political tone distanced itself from other related modes even as later generations of critics would deemphasize the form for prioritizing politics over artfulness. Without the politics of professionalization, or other sweeping cultural currents in Gilded-Age America that affected the class divide and the distribution of wealth, naturalism would not be naturalism; naturalist form is inherently a political mode that tended to advocate for individual agents over any larger force that threatened their autonomy. 


\section{Notes}

1. The mainline medical profession, allopathy, defended their interests with zeal as the nineteenth century concluded as they now possessed an epistemic legitimacy they had not had earlier in Antebellum America. The rise of bacteriology in Germany over the late decades of the century had a significant impact on the course of American medicine. German physician Robert Koch is famous for identifying the fact that cholera was a microbe and not a failing of the public health system or a failure of the nation's moral compass. Koch launched a program of bacteriology that put the Germans at the head of medical advancements as the century concluded. Historian Owen Whooley has documented the process of bacteriology reaching the United States by discussing Bruno Latour's argument that Louis Pasteur was able to get his pasteurization research agenda approved by enrolling allies, especially hygienists, in the project (156). To simplify a long historical process, some homeopaths attempted to embrace the new system of bacteriology, even in attempting to wed the two sects together under the umbrella of German nationalism, but the homeopaths could not agree on their philosophy as an 1886 article in the Homeopathic Physician proclaimed that "those who seek material causes of disease aided by the microscope will seek in vain" Because of this failure to accept the burgeoning new science, homeopaths lost their ability to conduct new research in the laboratory and thus found themselves relegated to the sidelines. Allopaths, on the other hand, already had an advantage following the Civil War as the American government only recognized them during the conflict. Allopaths then managed to find consensus in accepting bacteriology as hard medical science. American doctors started traveling to Germany to study the new medicine; almost all of the faculty at Harvard Medical School 
in the late nineteenth century, for instance, studied in German universities (Whooley 172).

2. Wells's work has been criticized in Studies in American Naturalism for this thesis not reaching its full potential. The reviewer, Chuck Robinson, notes that "Wells defines polemic as 'weaponized language.' Such broadness multiplies confusion: do we recognize naturalists by their polemics, or do we already have a set of known naturalists and suddenly realize they have been roped together all along due to their polemical bent? The author evades such questions by making long lists of characteristics, stylistics, and thematics of writers suspected of naturalism and then reminding us- as if somehow obviating the problems evoked by the lists— that "Yes, but they are polemic first."

3. Many scholars have contributed to the literature surrounding Steinbeck and his group of intellectual friends that included the likes of Joseph Campbell, Ed Ricketts, George and Richard Albee, and Steinbeck's wife Carol. Richard Astro first documented the various connections in detail in his 1973 book John Steinbeck and Edward F. Ricketts: The Shaping of a Novelist, and many prominent Steinbeck scholars have argued various ways each person in this circle likely influenced Steinbeck's literature in certain ways. In some of my previous work, I traced the influence of UCLA philosopher John Elof Boodin on Steinbeck's thought in the late 1930s and early 1940s, and a number of recent projects including Susan Shillinglaw's recent book on John and Carol's marriage have done so as well.

4. The story also has an ecocritical dimension that could be further explored. Regarding Steinbeck and Ricketts's Sea of Cortez voyage, Yanoula Athanassakis notes: "In Sea of Cortez the moments of trepidation over how marine life should be treated stem from 
Steinbeck and Ricketts's dim understanding that they are participating in the destruction of sea and animal life while trying to document and preserve it" (46). While that critique of Sea of Cortez is certainly a valid one, this analysis posits that Steinbeck consciously thought of the consequences of this idea earlier and more so than the current literature suggests. Ricketts, while a Renaissance man as well as a marine biologist, had long taken animal specimens, and as an apparent stand-in for Ricketts, Dr. Phillips does not think through the broader ramifications of taking life as well as preserving and creating a taxonomy of it.

5. In his recent book Citizen Steinbeck: Giving Voice to the People, Robert McParland adequately summarizes much of the critical discourse on The Pearl: "The Pearl has often been read as a moral tale about how greed for wealth and material possession is detrimental. An aesthetic approach to this story may, instead, focus on structure and the musicalization of fiction" (154). 
Chapter 4: A Return to the Philosopher Physician: the Satiric Realism of Sinclair Lewis's

\section{Arrowsmith}

\section{I: Introduction}

In previous chapters, this dissertation traced attitudes around allopathic practitioners across the nineteenth century as the profession lost its credibility while again regaining it after the Civil War. This chapter examines the end of this historical trajectory. Unlike other competitors like homeopathy, allopathy allied itself with German research developments in bacteriology, and its organization into the American Medical Association defined who could and could not practice medicine. By the 1920s, allopathy sat on firm ground as the dominant medical paradigm. However, as allopathic medicine shifted from empirical study of the patient to laboratory research, it needed capital to fund its advancements. While the taxpayers funded some of this with state medical schools, cutting edge research did not happen at universities as much as at private research institutions funded by billionaires like Rockefeller and Carnegie.

With the medical profession's embrace of corporate funding, Sinclair Lewis found ample material for his Pulitzer Prize winning novel Arrowsmith, published in 1925. The novel traces the life of Dr. Martin Arrowsmith through his days in medical school to various stops in his career, including a venture as a country doctor, a public health specialist, a researcher at a for profit pharmaceutical company, and finally, his defining role as researcher at the McGurk Institute, a fictional stand-in for the Rockefeller Institute. Lewis, at the time known for his satirizing caricatures of small-town America in books like Main Street and Babbitt, takes on a different project by caricaturing mainstream medicine. These caricatures did not fully arise out of Lewis's own ingenuity though, as several literary scholars have classified the novel as a roman a clef due 
to Lewis's collaboration with Paul de Kruif, a microbiologist who had grown disenchanted with the political working conditions at the Rockefeller Institute. ${ }^{1}$

This final chapter examines Lewis's satire in Arrowsmith as a natural end point in the history of the fall and rebirth of the professionalization of medicine. It argues that Lewis's Arrowsmith is a ruthless critique of mainstream medicine as its embrace of corporate funding creates unneeded bureaucracy that stifles scientific progress. The text suggests that in order to practice medicine in twentieth-century America within the profession, a physician must in some way sell out for the sake of career aspirations. Throughout the novel, Arrowsmith must abandon his ethics and scientific ambitions to practice amicably: the novel functions as a hero story as Arrowsmith encounters challenges that threaten to tarnish his scientific conviction. Furthermore, the novel lampoons the profession to the point that by the novel's end, Arrowsmith no longer has any options without feeling pressure to sell out from administrative interests.

This chapter reads Arrowsmith within the satiric mode. In doing so, we must re-examine the argument made about American Realism made in chapter two. In chapter two, we examined how American realism processed the theme of women doctors entering the profession through the marriage plot's resolution as perpetuated by Howells, along with surveying how writers like Phelps and Jewett exposed the formal unity provided by the formula as a contrived one. This section contends that Lewis's novel is another form of realism called satiric realism. While both forms share aesthetic similarities, such as an emphasis on plotlines not outside the realm of possibility, Lewis's satiric text does not heal social rifts but rather illuminates the problem of professionalization in a censorious tone. In total, Lewis's form exposes the unrealities of Howellsian Realism's neat symmetry in terms of plot and structure. ${ }^{2}$ 
The question about satire's interrelationship with realism has been discussed with the British novel. Aaron Matz's study Satire in an Age of Realism surveys late Victorian novelists associated with realism: writers such as George Eliot, Thomas Hardy, and George Gissing. English literature had embraced the conventions of classical Augustan satire, a mode that ridicules and seeks to correct societal ills, through writers like Jonathan Swift and Lady Montagu. In the late nineteenth-century, this ancient mode found itself in the same cultural consciousness as realism. The realist form, while attempting to represent the world as it was, invites censure at the social ills it exposes. As a result, the realist and satirical forms blurred into a form Matz calls satirical realism, "in which humans are portrayed with nuance—and yet are objects of ridicule simply for being there" (ix). Unlike Augustan satire, this new form gave up the illusion that social structures could be changed; instead, it relies wholly on a tone of pure censure without seeking to reform the issue. The result is a "very dark comedy whose laughter fails to be curative, or else it forbids us from laughing at all" (34). While Matz focuses mostly on the latter decades of the nineteenth-century, he traces these ideas back to earlier realists ranging from Flaubert to Thackeray, the latter being called "the legitimate high priest of Truth" by Charlotte Bronte for his scathing depictions of Victorian society in works like Vanity Fair. ${ }^{3}$ It is difficult here not to see shades of American satirists: Twain being chief amongst them.

While Matz's text is about Victorian novelists, we can extend his term satirical realism to our discussion of Lewis's medical novel. Arrowsmith likewise does not produce a curative laughter; rather, it is a large-scale censure of the medical profession. It should also be noted that American Realism lacked the same fervor as the Victorian brand; instead of censure, Howells and his proteges tried to heal social rifts through the conclusions in their novels. This chapter contends that Lewis borrowed the same sort of zeal from the British novelists in his censorious 
tone. What results then is a novel diametrically opposite to the Howellsian novel: in a tone of censure without seeking to remedy the ills, the novel can only leave Martin alone since he cannot function within such a flawed system.

Lewis's satire exposes the unrealities of the Howellsian desire for structural and thematic unity. Our theoretical context for this reading of Arrowsmith is Charles Knight's article "Satire, Speech, and Genre." He argues that satire's insistence on historicity proclaims the actuality of experience and the inadequacies of generic and linguistic codes to represent it" and that "its insistence on the mental constructions implied by its literary character mocks the thoughtlessness of experience in relation to the possibilities conceived by the mind" (38). Knight's claim about the satiric form applies to Arrowsmith; unlike the form of American Realism perpetuated by Howells, whose formal unity can seem contrived, Lewis's satiric text does not arrive at any unity with the way it processes these contradictions. After the novel disassembles the medical profession piece by piece, it ends with an ending that feels jarring in that the satiric tone overwhelms the realist desire for unity, which in turn leaves many readers feeling unsatisfied since, through the novel's engagement with realism, readers are left with those expectations. Martin leaves his new upper class wife and top tier research job to research medicine in the woods. This ending suggests that the profession is incompatible with individual genius; no longer can a Koch or a Pasteur thrive in a corporate and public environment that stifles innovation. Martin cannot practice primary care for public pressures, nor can he conduct pure research without political interference; therefore, he exits the profession and relies on his ingenuity and convictions.

This chapter suggests that in order to identify the form of Lewis's satiric novel along with how the satiric form engages with realism, a useful point of comparison to note would be Leo 
Marx's famous reading of The Adventures of Huckleberry Finn in "Mr. Eliot, Mr. Trilling, and Huckleberry Finn." Marx's argument centers on how the ending does not resolve the profound themes in Twain's novel: his critique is that "the controlling principle of form apparently is unity, but unfortunately a unity much too superficially conceived... a unified work must surely manifest coherence of meaning and clear development of theme, yet the ending of Huckleberry Finn blurs both" (434). While Marx at the time saw this lack of unity as an aesthetic failure on Twain's part, as he thought that Twain refused to acknowledge the truth his novel contained, this chapter contends that was the point entirely; Huck is powerless to change his world, just as Martin, despite his ingenuity, is left powerless by the profession. Both these characters are thus heroic outsiders who embrace self-reliance and must "strike out for the territories" because the realist mode cannot contain the unrealities present in their worlds.

\section{II: Historical Contexts: The Dominance of Allopathic Medicine}

As mentioned in the introduction, Arrowsmith follows at the end of this dissertation's historical trajectory as allopathy again regained its prestige; however, Lewis holds back nothing in ridiculing how the profession evolved into something that he perceived as no longer caring for the advancement of medical innovation in its emphasis on sustaining and advancing the profession. This dissertation traced most of this trajectory in the third chapter on naturalism; however, the key strand involving this study of Lewis includes corporate financing of medicine as well as the state of the profession with the prominence of new subgroups like public health officials. The turn of the century saw wealth turn to the hands of a few rich industrialists and speculators; the disparity grew so large that J.P Morgan even bailed the US Government out of debt in 1895 (Esposito). Andrew Carnegie's text "The Gospel of Wealth" is a primary text that explains how some of the wealthier individuals favored re-distributing wealth through charitable 
organizations that advance the cause of mankind rather than re-distributing the wealth through measures like a system of progressive taxation. Carnegie argued that "it was better for mankind that the millions of the rich were thrown to the sea than so spent as to encourage the slothful, the drunken, the unworthy. Of every thousand dollars spent, it is probably that $\$ 950$ is unwisely spent...as to produce the very evils which it proposes to mitigate or cure" (Carnegie.org). Carnegie thus advocated for investing in projects that would benefit the public at large: libraries, parks, etc. From Carnegie's perspective, if a rich man left behind abundant wealth after his death, that man would have the right to not be celebrated: "the man who dies thus rich dies disgraced." The influence of figures such as Carnegie cannot be denied as advancing the interests of the public; however, this mentality did affect professions such as medicine seeing how private benefactors now controlled the output of the profession. While Carnegie was most known for his major infrastructure projects, he did invest in Abraham Flexner's reports on medical schools in America that shifted the future of medical education into the new century. ${ }^{4}$

John D. Rockefeller adapted Carnegie's thinking towards charitable contributions by investing in the medical profession. Rockefeller's advisor, Frederick T. Gates, and later his son, John D. Rockefeller Jr, managed this money. Gates envisioned medicine working with the same industrial innovations as the oil business as "the precise analysis of the human body into its component parts is analogous to the industrial organization of production" (201). By 1901, the group founded the Rockefeller Institute for Medical Research, which in addition to its research efforts donated 129 million dollars to medical education by 1929, the equivalent of 1.6 billion dollars today adjusted for inflation (Whooley 217). The Institute embraced allopathic medicine's acceptance of bacteriology and hired scientists to do their work without the "sordid considerations" of the American public interfering (202). Bacteriologists at the Institute had 
unlimited resources, and many medical practitioners sought careers in the laboratory instead of at the bedside of the patient. Despite Rockefeller's own appreciation of homeopathy, Gates put the Institute's resources into allopathy, as he was himself a critic of homeopathy, arguing that founder Hahnemann was 'little less than a lunatic' and that the sect thrived on the 'ignorance and credulity of patients" (qtd. in Whooley 202). With all this context in mind, this chapter will showcase how the idea of the aspiring scientist seeking truth with the unlimited resources of the Institute was purely idealism as the scientists at the Institute faced internal pressure to publish their findings when not ready along with serving as public relations figures.

As allopathy shifted away from public funding to more of a private, corporate model, the second half of the nineteenth century also emphasized democratic medicine through public health boards and officials. This medical sect suggested that the root cause of diseases like cholera was filth in the cities, so public health boards then worked to clean up towns and cities while rallying the public to join them. Public health boards welcomed sects like homeopathy into their fold, much to the chagrin of the American Medical Association and its practice; many allopathic practitioners refused to work with their homeopathic peers on public health boards. To clean up the cities, public health officers used quantitative data like statistics and surveys to assess the places that needed treatment. An interesting side note in the public health movement involves the professionalization of plumbers seeing as how their labor was needed to reach the root cause of disease, filth (Whooley 138). In general terms, public health boards caused consternation among allopaths because it was susceptible to so many outside groups and pressures, even though allopaths participated on the boards. Because of its democratic roots, these public health boards were also susceptible to corruption and political opportunists, and, as 
we shall see later in the chapter, this type of corruption would become the object of scorn in Lewis's novel.

\section{Relevant Critical Scholarship on Arrowsmith}

This chapter adds to the critical conversation on Arrowsmith by providing a discussion of the novel's form alongside its social function. Early criticism of the novel focused on character analysis and aesthetics. The first academic conversation involves a discussion of the scientist as hero along with asking to what extent the profession makes him a hero. Lewis's biographer Richard Lingeman notes that the 'hard men' of science were Lewis's heroes; they embodied the traits Lewis personally valued: a capacity for heroic stints of lonely work (like a writer,) integrity, rebelliousness, and disdain for fame and money" (222). Lewis admired allopathic laboratory researchers who, while not practicing medicine themselves, sought to innovate the profession even while dealing with outside pressures for results or publications. This strand featured widely in the criticism of the 1960 s regarding the novel. ${ }^{5}$ There has also been notable scholarship offering aesthetic judgments on Arrowsmith from critics Frederick Carpenter and Howard Bloom. ${ }^{6}$

Another strand in Arrowsmith scholarship features biographical and political criticism of Lewis and the world he satirized. Michael Augsburger, for instance, reads the novel as a political satire where the individual genius of Martin is stifled by numerous agents, including professional doctors, with their own agendas (85). ${ }^{7}$ This chapter also extends some larger discussions about satire into its discussion of the novel. Many scholars have read the novel as a roman a clef in that Lewis collaborated with a friend, Paul de Kruif, who worked at the Rockefeller Institute, during the novel's composition. When a text is a roman a clef, it assumes that a reader complicit in the satire has the code to crack what fictional representations stand for 
real-life characters, so much of the work centers on those biographical details. Recent political criticism on the novel has examined the postcolonial implications of the McGurk Institute conducting experiments in the Caribbean in the novel with regards to American imperialism. ${ }^{8}$ With all said, this chapter adds to the existing scholarship by discussing how Lewis unites the satiric mode to disrupt the formal conventions of conventional American realism. While there have been numerous studies examining the biographical or political subtexts in the novel, none have sought to combine discussions of form and aesthetics with the novel's politics, especially the politics of medical professionalization.

\section{IV: Lewis's Satire of the Professions in Arrowsmith}

Lewis's novel is a piece of fiction that has a central theme: the social politics behind the professionalization of medicine. The novel's structure is a bildungsroman that shows Martin (Arrowsmith) aspiring to enter a changing profession from the opening pages and ends with Martin's disgust with the social politics influencing his work causing him to withdraw into the woods while conducting independent research. Lewis' satiric attack reduces the medical profession into a reduction ad absurdum. If one assumes Lewis's audience consisted of middleclass readers or perhaps readers aspiring to become middle-class professionals, then one can imagine such an audience found a representation of their frustrations following Lewis's satiric attack. However, the novel does not leave room for nihilistic doubt about the profession as it suggests that a social emphasis on individual genius and nonconformity for doctors is for the greater good of society and patients more so than a profession entangled with a desire to sustain itself at the cost of scientific advancement or a patient's well-being. The novel's function thus suggests that a return to older ideals, the scientist philosopher aspiring for knowledge for 
knowledge's sake, is the optimal way to break out of the stranglehold that the medical profession placed on personal ingenuity.

The other central concern regarding Arrowsmith is Lewis's interrogation of the realist novel. Madeline is Martin's first girlfriend in the novel, an English graduate student whom he finds pretentious. She takes graduate courses in English, and her favorite writers include realists like "Hardy, Meredith, Howells, and Thackeray, none of whom she had read for five years. She had often reproved Martin for his inappreciation of Howells, for wearing flannel shirts, and for his failure to hand her down from streetcars in the manner of a fiction hero" (472). While this passage will be discussed more in detail later, this mention of the realist authors suggests that Lewis's own text is a response of sorts to these realist writers. While Howells is the standard flagbearer of American Realism, the mention of British realists like Hardy and Thackeray suggests that Lewis's novel is conducting similar cultural work. While Howells himself wrote several satires, the mention of the likes of Thackeray and Hardy suggests a realism grounded more in censoring and chastising the society it represents. With all said, however, Lewis's novel mentions these names in a way suggesting a cultural pretension of the realist mode. The realist mode can no longer contain the social contradictions inherent with a social movement like professionalization; therefore, something new must emerge that exposes the unrealities of the form. An American form of satiric realism thus emerges.

In the spirit of Matz's definition of satiric realism, Lewis's portraits of the novel's many characters are nuanced despite the novel's censorious tone. Lewis's first sketch is Doc Vickerson, a comic sketch of the old country-doctor figure who barely received any medical training other than interning himself. Operating in Elk Mills, a town in the fictional Midwestern state of Winnemac, Vickerson attends to all needs of his patients, and his multipurpose office 
served as business office, surgery room, poker den, and a warehouse for guns and fishing tackle (448). Lewis's narrator pokes fun at Vickerson in a way that romanticizes this old guard of doctors before the emergence of the profession:

On the senile table was a pile of memoranda of debts which the Doc was always swearing he would 'collect from those dead-beats right now,' and which he would never, by any chance, at any time, collect from any of them. A year or two-a decade or two - a century or two - they were all the same to the plodding doctor in the bee-murmuring town. (448)

This passage waxes nostalgic at the early nineteenth-century state of the profession as the doctor stood as the pillar of the community as he did enough to make ends meet and took care of his patients without professional scruples or greed involved. Vickerson put his patients first, even if he didn't know what he was doing. Vickerson stands as an exemplary self-reliant hero of sorts early in the novel; while a relic of the past, his aspirations for his work transcended any professional conformities that Martin would later face.

Furthermore, Lewis describes Vickerson's knowledge and cultural capital in the same chapter, and the purpose of this description illustrates the extent to which medicine became a profession instead of a craft. The decline of people like Vickerson also showcases America's changing identity with the closing of the frontier in a manner resembling Frederick Jackson Turner's "Frontier Thesis" in that it laments the closing of the frontier as American visionaries could no longer move West. This section again romanticizes the former state of the profession, but Vickerson acknowledges how his way of life is over as he predicts how the profession is a new middle-class entryway into respectability: "Reading old Gray? That's right. Physician's library just three books: 'Gray's Anatomy” and Bible and Shakespeare. Study. You may become great 
doctor" (450). Vickerson continues by noting the type of training Martin will need within the new economy: "Get training. Go college before go medical school. Study. Chemistry. Latin. Knowledge...Training, that's what you got t' get. Fundamentals. Know chemistry. Biology. I nev' did" (450). The chapter ends with Vickerson remembering his work as a medical pioneer, including putting together a small museum of medical specimens and performing procedures like appendectomies for the first time in the Ohio Valley territory. The chapter predicts the end of the old guard-Vickerson, a physician who started as a barber-with the new with specialized knowledge; however, the fact that Vickerson accomplished so much with Gray's Anatomy, the Bible, and Shakespeare as his resources suggests a sense of personal self-reliance and ingenuity that Martin would see later with his future mentor, Dr. Gottlieb. While the profession offers specialized knowledge in the sciences, which results in medical advancements, it will take medical visionaries to transcend medicine to the next level, just as Vickerson did by taming the frontier. Vickerson's mention of Latin also suggests that this new class of professionals must possess a certain amount of cultural capital seeing how many nineteenth-century pundits saw it as being an elitist form of knowledge unique to the professional class, especially considering that anatomical terms originated with it. From the onset, the novel thus forecasts the politics of professionalization. When Martin goes to study at the University of Winnemac, Lewis also satirizes the state university as a mill for creating respectable, middle-class citizens. If one reads the novel as a roman $a$ clef, then critics have argued that Lewis's University of Winnemac is a fictional stand-in for the University of Michigan as a state institution (Markel 372). In the early twentieth century, receiving a liberal arts education theoretically trained students to become well-rounded American citizens and proved to be the popular model among upper-middle class or rich students; however, the novel showcases how state universities began to turn more towards a skill-based practical model with 
the hope of expanding the middle-class beyond those people trained at liberal arts institutions, and this model provokes the narrator's scornful exposition:

It is not a snobbish rich-man's college, devoted to leisurely nonsense. It is the property of the people of the state, and what they want - or what they are told they want — is a mill to turn out men and women who will lead moral lives, play bridge, drive good cars, be enterprising in business, and occasionally mention books, though they are not expected to have time to read them. It is a Ford Motor Factory, and if its products rattle a little, they are beautifully standardized, with perfectly interchangeable parts. Hourly the University of Winnemac grows its numbers and influence, and by 1950 one may expect it to have created an entirely new worldcivilization, a civilization larger and brisker and purer. (453)

Considering that medical schools began to demand an undergraduate education to enter the profession as admission for medical school during this period, the narrator implies that becoming a product of this industrial factory-like setting will create a standardized personal product who will conform to corporate American ideals rather than molding individual thinkers. The University of Winnemac is not a school that produces thinkers, like a liberal arts school, but rather standardized products. The narrator thus raises the question: if the profession requires this sort of education, then what hope does it have to create critical thinkers? We see here another example of Lewis's own brand of satiric realism; his satire does not leave much room for hope or change so long as the university mass produces robots. This passage is essential in creating the novel's conflict as Martin negotiates the boundaries between professional respectability and scientific and personal integrity. 
Lewis spends about a third of the novel detailing Martin's schooling at Winnemac, where the novel introduces many of Martin's mentors and classmates. Professor Gottlieb becomes Martin's idol; however, it takes almost the entire novel for Martin to accept the perspective that knowledge for knowledge's sake outweighs the concerns of the profession like making money or even healing individual patients. Gottlieb embodies the self-reliant, philosopher intellectual who stands apart from his peers. ${ }^{9}$ Lewis's narrator goes out of his way to characterize Gottlieb as a Thoreau-like transcendentalist by juxtaposing him with his colleagues: "while medical quacks, manufacturers of patent medicines, chewing-gum salesmen, and high priests of advertising lived in large houses, attended by servants, and took their sacred persons abroad in limousines, Max Gottlieb dwelt in a cramped cottage whose paint was peeling, and rode to his laboratory on an ancient and squeaky bicycle" (587). Gottlieb is the opposite of the previous characters surveyed; as a philosopher, he does not care about material possessions or his class-standing by the size of his house or a fancy car. Instead, he is a modern philosopher of sorts as he lives not for fame but for advancing knowledge for knowledge's sake.

Gottlieb proves to be an ill-fit for the modern medical school as his independent thinking outweighs the University of Winnemac's mission to create respectable members of the community. Early in the novel, during Martin's first day of medical school, he asks Gottlieb if he can take his bacteriology course earlier than the curriculum dictated. Gottlieb refuses with an elaborate metaphor comparing his students to potatoes:

one kind (of student) they dump on me like a bushel of potatoes. I do not like potatoes, and the potatoes do not ever seem to have great affection for me, but I take them and teach them to kill patients. The other kind — they are very few! — they seem for some reason that is not at all clear to me to wish a liddle bit to become 
scientists, to work with bugs and make mistakes. Those, ah, those, I seize them, I denounce them, I teach them right away the ultimate lesson of science, which is to doubt and wait. Of the potatoes, I demand nothing: of the foolish ones like you, who think I could teach them something, I demand everything. (458)

Gottlieb's potatoes spread to become mainstream and specialized physicians who become respectable members of the community. Such students cannot demonstrate the critical initiative needed to be a scientist seeing how they must maintain their status, oftentimes at the detriment of the patient, by treating symptoms rather than root causes. Nonetheless, his denouncing of many of his students indicates Gottlieb's way of thinking is not sustainable in the mainstream profession. With the standardization of the new allopathic medicine, Gottlieb does not have the same freedom to pursue his philosophical inclinations as an early nineteenth-century American physician had. Gottlieb resembles the sort of physicians surveyed in chapter one of this project whom the gothic mode represented: a scientist who through his pursuit of knowledge cares more about science than treating patients or practical results.

Gottlieb, as a bacteriologist, sees humanity in terms of a broader worldview. As a twentieth century scientist who researches microbes, Gottlieb deemphasizes a humanistic worldview in favor of a cold, albeit utilitarian perspective on medicine. He wonders if the world would become overpopulated if tuberculosis was eradicated, and the narrator notes that "he doubted all progress of the intellect and the emotions, and he doubted, most of all, the superiority of divine mankind to the cheerful dogs, the infallibly graceful cats, the unmoral and unagitated and irreligious horses, the superbly adventuring seagulls." As such an independent thinker, Gottlieb clashes with the administration at the medical school; he tells the college president that "You are too busy to consider anything but selling honorary degrees to millionaires for gymnasiums" (591). His 
colleagues then remove him from the academic profession, accusing him of insubordination, a refusal to collaborate with colleagues, insane egotism, and even atheism (592). These ridiculous accusations satirize the groupthink evident in professional circles: despite his contributions to science, Gottlieb is cast aside by his peers for petty reasons. However, Gottlieb is not compatible with his peers for deeper ideological perspectives; his view of the universe resembles that of many modernist painters and writers; all at once, with all the new advancements in science and warfare, humanistic philosophy lacks the same persuasive appeal it once possessed due to a broader worldview. Gottlieb refuses to conform to old traditions, and he cares nothing about his place in the profession; therefore, he is one of the few scientists who can advance medicine since he transcends all professional, material concerns. Gottlieb is a scientist physician more than a healer per se; in a world where the profession works to fashion itself as a staple of American culture, Gottlieb is an outsider who by his 'dangerous' inclinations cannot sustain himself in the profession; the newfound profession cannot accept someone who is not a humanist.

As an aspiring young professional, Martin finds himself seduced more by other professors and even students at Winnemac than Gottlieb, which in turn causes the discontent he feels throughout the novel as he changes both jobs and towns without a sense of accomplishment in his work. For Martin, Dean Silva, the antithesis of Gottlieb, is such a figure. Gottlieb paints Silva as a college administrator more worried about pandering to the community than advancing science: "once I asked Dean Silva would it not be better to let loose the pathogenic germs on the world, and so solve all economic questions. But he did not care for my meth'od....he is older than I am; he also gives, I hear, some dinner parties with bishops and judges present, all in nice clothes" (489). When Gottlieb tells Silva that he needs to step down to transform Winnemac into a more research-intensive medical school, Silva replies that "while he could see the value of basic 
research, the medical school belonged to the people of the state, and its task was to provide them with immediate and practical attention" (591). Again, the tension between scientific advancement and the desire to create practical professionals arises in the novel. Silva does, however, get a chance to imprint his opinion onto Martin:

It's all very fine, this business of pure research: seeking the truth, unhampered by commercialism or fame-chasing. Getting to the bottom. Ignoring consequences and practical uses. But do you realize if you carry that idea far enough, a man could justify himself for doing nothing but count the cobblestones on Warehouse Avenue-yes and justify himself for torturing people just to see how they screamed - and then sneer at a man who was making millions of people well and happy! (582)

Silva reinvokes the same fears that this dissertation examined in the gothic chapter-the idea that the overly ambitious philosopher physician will put science above medicine to the point that the patient is forgotten or even abused in the quest for scientific progress. For civilization to function, it needs a class of professionals dedicated to treating patients first. Lewis presents both sides in comic exaggerations, but nonetheless ones grounded in some reality. While it's tempting to read Gottlieb as the heroic rebel, Silva's points are well-taken about the need for traditional practitioners. The tension between being a professional versus advancing science thus grows with the conflict between the two men, and it escalates for Martin as he later becomes a researcher for the McGurk Institute.

Lewis further accentuates the tension between professionalization and scientific integrity with his caricature of Dr. Roscoe Geake, professor of otolaryngology, and the idea of commercialism that he invokes. Unlike Silva, a figure whom Martin admires, Martin detests Geake 
for his lack of imagination and his susceptibility to commercialism. Lewis sketches the aptly named Geake as a physician who believes every patient needs their tonsils pulled whether they need it or not, and he chronicles a speech Geake gives to the medical students about the utility of selling their knowledge:

Whether a patient is a new or an old friend, you must always use salesmanship on him. Explain to him, also to his stricken and anxious family, the hard work and thought you are giving to his case, and so make him feel that the good you have done him, or intend to do him, is even greater than the fee you plan to charge. Then, when he gets your bill, he will not misunderstand or kick." (540)

Later in the novel, once Martin settles into a country doctor position, he reads an advertisement for a medical office furniture magazine: "Just a little down and the rest free—out of the increased earnings which New Idea apparatus will bring you!" (618). While Martin uses plain chairs, he does decorate his office with a plate-glass sign with gold letters that said, "M. Arrowsmith, M.D.” (620). The novel's satire on professional ethos again tilts its ideological argument back toward the self-reliant scientists. Geake's lecture paints his profession as a group more concerned about material appearances and cash more so than even the needs of his patients with his choice of words like "intend to do him" and "the fee you plan to charge." Nonetheless, Martin is seduced by these lectures with his gold-lettered sign, a symbol of status that functions in the same manner as McTeague's gold tooth in our previous chapter on naturalism.

Lewis sketches Martin's classmates at Winnemac to also juxtapose Martin's love of knowledge for knowledge's sake versus his classmates' desires to become respectable members of the community; the novel does so by poking fun at the lack of scientific ambition certain respectable subsections of medicine possess. The successful Angus Duer becomes an object of 
Martin's scorn. Angus goes to medical school aspiring to become a surgeon; Martin believes that this subsection of medicine does not produce original thinkers but rather human machines who memorize and regurgitate facts: "He knew that in biology Duer had been too busy passing examinations to ponder, to get any concept of biology as a whole" and in chemistry Duer "neatly and swiftly completed the experiments demanded by the course and never ventured on original experiments which, leading him into a confused land of wondering, might bring him to glory or disaster" (462). Throughout the novel, Angus becomes a respectable surgeon: the narrator notes: "Angus was one of the few who knew without wavering precisely what he was going to do: after his internship he was to join the celebrated Chicago clinic...He would...be making twenty thousand a year as a surgeon within five years" (574). Later, after Martin's failed venture in public health, Duer gives him a job working in the private sector, and Martin conducts his bacteriology experiments on the side. Angus scolds him for doing so, claiming that if he published a journal article on a practical subject related to surgery, his clinic might see fit to give Martin "three thousand a year then" (762). One of Angus's last mentions in the novel comes in the last pages of the novel, where the narrator chronicles that he is "head of the Duer Clinic and professor of surgery in Fort Dearborn Medical College" (964). These passages all indicate the novel's key conflict between a complacent medical profession versus the heroic calling of science. Despite being skilled at his craft, Angus is a craftsperson and not a holistic, innovative thinker. The fact that Angus achieves professional success making money whereas Martin struggles also suggests that the profession rewards those whom Martin perceives as pragmatic, unoriginal thinkers compared to philosophers and/or scientists; in America's new, corporate economy, skills are valued more than critical thinking and innovation. 
Once Martin becomes a physician, he travels all across America working in a variety of medical positions; in each one, Lewis characterizes Martin as a frustrated scientist who either does not have the time to conduct his meaningful work in a corporate environment or else has outside political pressures bearing on him. In his first position, Martin serves as the country doctor archetype that was surveyed in the realism chapter; this figure works to put patients and the community first. Martin works in Wheatsylvania, North Dakota, a town of 362 inhabitants, seeing that is where his wife Leora's family lived. This section of the novel reads much like other Lewis works as the events transpiring make rural America look ridiculous. Martin must deal with the locals in order to draw business: some figures of which include the local pharmacist who knows nothing about prescriptions, the local religious figures who scold him for gambling and not attending church, and even Leora's own brother, Bert, who is skeptical about the medical profession: “Oh, you docs!...You're all alike, especially when you're just out of school and think you know it all. You can't see any good in chiropractic or electric belts or bone-setters or anything, because they take so many good dollars away from you" (614). To gain a sense of ethos with the locals, Martin even must consult with Doc Winter, the doctor in the next town, and pay him a fee to avoid any local scrutiny. Martin finds little value in trying to negotiate local politics with these comic small-town caricature characters; therefore, he does not stay in Wheatsylvania long.

Beyond his disdain for local politics, Martin's specialized knowledge in bacteriology does not meet the local town's needs for a generalist skilled at several mundane tasks. This again suggests that a professional should be a skilled laborer and a shaman of local wisdom more than a scientist: "Dad Silva had warned his classes, 'Don't forget the country doctor often has to be not only physician but dentist, yes, and priest, divorce lawyer, blacksmith, chauffeur, and road 
engineer, and if you are too lily-handed for those trades, don't get out of sight of a trolley line and a beauty parlor"' (621). Martin later consults with other doctors due to his failure to save a young girl from diphtheria. He gets lost on the way, and finding her on her deathbed, Martin freezes and does not want to operate, which is traditional procedure. He goes to town seeking antitoxin, in which time the girl dies seeing as how he waited too long. This entire episode showcases the conflict between scientific progress through specialization and the generalized knowledge required of healers. Although Martin is qualified to advance the knowledge of medicine, he finds himself incompatible with the practical skills needed to be a successful practitioner. Thus, through Lewis's satiric look at both the complete knowledge needed of a country doctor alongside Martin's inability to handle it, we notice a professional discrepancy as the profession no longer equips its doctors to be a local sage. Even Angus Duer, a specialized surgeon, likely would not succeed in his venture in rural America.

Martin's next venture is that of a public health official, and here Lewis satirizes and ridicules the local politics and corruption required to thrive in the position. Martin attempts to merge his bacteriological talents with public health, which are two things appearing compatible on the surface, to no avail. Moving to conservative Nautilus, Iowa, Martin's supervisor is future congressman Dr. Pickerbaugh. Instead of practicing medicine in his role as public health specialist, Pickerbaugh relies more on expert marketing by creating jingles such as "Sell your hammer and buy a horn/ but hang onto the old fly-swatter/ If you don't want disease sneaking into the Home/ then to kill the fly you gotter!” (702). As Pickerbaugh's deputy and later replacement, Martin must negotiate the divide between being an independent scientist versus communicating complex ideas to the public, and because Martin cannot do this job alongside maintaining his scientific and personal integrity, he fails at it. 
Unlike Pickerbaugh, a masterful politician and marketing expert, Martin cannot perform the job of public health authority because his knowledge of how bacteria spread conflicts with the practices of local industry figures. Public opinion turns on Martin; he no longer attends social gatherings with the town's elite members in his obsession with the job. The town cuts his pay and later demotes him to a subsidiary position forcing him to quit despite his doing a competent job at maintaining public health. The novel does this to reduce yet another medical subfield, public health administration to absurdity, indicating that the profession, with its desire to maintain its middle-class privilege, cannot maintain those who defy the status-quo of larger economic interests. Numerous incidents happen here: Martin upsets his former classmate, Irving Watters, because the public health clinics take business away from the local town doctor (742). Discovering that a case of streptococcus existed in several cows in the local dairy, Martin shuts down the operation, which in a dairy town causes great consternation. The profession does not come to Martin's rescue because of their business interests. In his desire for seclusion to work on his science, Martin also makes an enemy of the Tredgolds, the wealthiest and most respectable family in the town. These factors add up to showcase how complicit the profession is with business interests. Despite Martin acting in the best interests of Nautilus, the town chastises him for shutting down the dairy. His fellow doctors show more regard for their money than their patients. And no matter how competent he proved with his work, Martin had to indulge in the social rituals necessary to survive in the town, which interferes with his time to conduct research. Because of all these local interests, Martin is thus left with only a few more possibilities to innovate medicine.

This latter third of the novel best showcases Lewis's relentless attack in illustrating the profession's complicity with larger corporate interests in its attempt to preserve itself. After the 
disaster in Nautilus, Martin moves to the private, corporate sector, first in a short-lived position at a for-profit pharmaceutical company and then as researcher as the McGurk Institute. If we take for granted that the novel is a roman a clef from De Kruif's accounts, then one can understand the level of vivid detail in this section. It is significant that here, Martin is given time to innovate within his field while working alongside Gottlieb. During this portion of the novel, Martin also earns the highest salary of his career and manages to live comfortably in New York City, ascending into the professional middle class. Despite his efforts, he finds that he is not free from outside influences to make the McGurk Institute appear prestigious, and due to these instances, Martin realizes that the only way he can pursue his work is through being a self-reliant entrepreneur.

At McGurk, life at first seems ideal for Martin as he pursues the life of the mind; however, it does not take long for the science for science's sake position to wear thin as he faces bureaucratic pressure to produce. Martin now works for Gottlieb, who gives him a stern lecture on the ideal scientist, a point well taken after Martin's failed experiments working as a practitioner: "the normal man, he does not care much what he does except that he should eat and sleep and make love. But the scientist is intensely religious - he is so religious he will not accept quarter-truths, because they are an insult to his faith" (767). Unlike the "ridiculous faith healers and chiropractors" who are pseudoscientists, the authentic scientist is "the real revolutionary... because he alone knows how liddle [sic] he knows" (768). Martin also befriends a new colleague, Terry Wickett, who cares more about his science than good manners; Wickett becomes his companion at the novel's end once the Institute's politics become too much to bear for both men. While this position is more suitable for Martin than his previous ones, Martin's inability to navigate the political pressures showcases how complicit the profession, including 
the scientists, is with America's new wealth. In an age of private research over state-funded work, a profession that exists for the sake of knowledge production no longer exists.

Lewis's satire on the Institute starts with his characterization of Ross McGurk, the fictional stand-in for Rockefeller, although some details of his biography differ from those of Rockefeller for likely legal reasons. The narrator characterizes him as a man who created the Institute to appease his overbearing wife Capitola so that he could keep her "itching fingers out of his shipping and mining and lumber interests, which would not too well have borne the investigations of a Great White Uplifter" (783). The narrator does paint McGurk as interested in the Institute's affairs, showing how he befriends Gottlieb, but he does not dare question Capitola's meddling. In one anecdote, Capitola visits Gottlieb's laboratory "to tell him that large numbers of persons die of cancer, and why didn't he drop this anti-whatever-it-was and find a cure for cancer" (784). Capitola also mandates fancy dinners for the scientists where she invites other high society people, and she parades them around the private laboratories. One rich lady who is married to a general practitioner remarks to Martin: "I don't see a single thing that's interesting...can't you or somebody create life out of turtle eggs, or whatever it is? Oh, please do! Pretty please! Or at least, do put on one of these cunnin' dentist coats that you wear" (787). It does not require extensive analysis here to illustrate the degree of satire Lewis bestows on the profession's complicity with America's new wealth. This sort of meddling from Capitola showcases the type of annoyances even those devout practitioners of science must endure.. If we also accept that the novel is a roman a clef about De Kruif, then it is also safe to infer that this is where the novel's major thematic underpinning comes full circle as the scientist versus the profession theme is intensified while the stakes grow higher as Martin now must justify his work to billionaires. 
In addition to the meddling of Capitola in professional affairs, Martin must also deal with the institute's administrators who run the day to day affairs. With these characters and their policies, the novel again showcases the absurd nature to which the profession has become complicit with its upper-class benefactors since the administrators serve at the whim of Capitola. Martin serves under two McGurk administrators, Drs. Tubbs and Rippleton Holabird. Tubbs offers the Institute's assistance in serving America during World War 1, where Tubbs becomes a Colonel, Holabird a Major, and Martin and Wickett were appointed honorary captains. The Institute forced its new officers to wear uniforms to work, and Tubbs forces the scientists to listen to luncheon lectures on "the part America will inevitably play in the reconstruction of a Democratic Europe" (797). The main result of these proceedings is that anti-German hysteria grows against Gottlieb at the Institute. These frivolous events in seeking to inspire patriotism only result in an ugly nationalist turn. These events again illustrate the downfalls of a profession that cannot exist independently without the influence of a larger agenda.

Holabird's role in the novel resolves the novel's entire plot thread concerning the tension between the profession and scientists. In the novel's climax, Martin travels to the Caribbean and tests his phage on the population. In order to run a successful test, Martin must disregard the public good and not give the phage to everyone so that he can test control groups, which is a course Gottlieb urges Martin to take: "You must not be just a good doctor at St. Hubert. You must pity, oh, so much the generation after generation yet to come that you can refuse to let yourself indulge in pity for the men you will see dying...dying...it will be peace" (854). During his time there, Martin succumbs to pitying the patients rather than advancing science, mostly due to the sudden loss of Leora, which will be discussed more in the next section. The experiment is ruined, but upon arriving back in New York, Holabird demands that Martin publish his results 
for the sake of the Institute's prestige. It is at this pivotal moment where the novel's tension between the profession and good science resolves itself: Martin realizes that if he wants to be a true scientist, he cannot endure working within the profession. While he does take some time before resigning his position upon returning while he marries Joyce, Martin's optimism that he can conduct true science in the spirit of Gottlieb vanishes.

\section{V: The Women of Arrowsmith: A Study of Social Class}

In addition to examining Martin's comprehensive survey of the profession, this argument also must mention the role of women in the novel to further illustrate the degree to which the novel interrogates the idea of the new professional middle-class. Little scholarly conversation has happened with regards to the female characters within Arrowsmith. ${ }^{10}$ This argument suggests that Lewis uses Martin's love interests: his first girlfriend Madeline, his first wife Leora, and his second wife Joyce as characters who signify the social class they represent. These women all offer Martin something different in terms of social and cultural capital, and Martin's conflicts in his relationships all center on how much he wants to ascend the social ladder at any given moment in the novel. By the novel's end, after Martin climbs as high as possible, he discards his relationship with Joyce and by extension all women; he cannot mend his relationship with Joyce because Martin associates women with his social standing, which he discards in an act of transcendental self-reliance. The function of women within the novel's construction thus centers on social class; a divorce from the profession parallels his divorce with the opposite sex.

The first woman who influences Martin in the novel is the aforementioned Madeline, an aspiring young English academic who reads realist novels. As Martin works toward his degree, he courts Madeline, and her knowledge and cultural capital invokes an inferiority complex in him. In chapter three, this dissertation argued the major extent to which Howellsian realism 
endorsed the ideologies of the professional middle class; here, the mention of Howells acts as a signifier to suggest a cultural pretension of this new class. The fact that Madeline had not read Howells in several years that young in her career despite name dropping him suggests that this sort of elite knowledge gives her a sense of cultural capital. As mentioned, it also showcases an unreality in the realist form since Madeline, an advocate for the form, has little in common with the novel's heroic individual. In this way, Madeline's already established cultural capital threatens Martin, who does not think long about leaving her for Leora.

In the same passage, Madeline laments that some of her fellow academics go into academia to teach and not conduct research; however, she muses that doctors are fortunate to enjoy a level of practicality that academics cannot and that practical doctors are more useful to society than scientists: "Look at a surgeon like Dr. Loizeau, riding up to the hospital in a lovely car with a chauffeur in uniform, and all his patients simply worshipping him, and then your Max Gottlieb...he had on a dreadful old suit, and I certainly thought he could stand a hair-cut" (474). After Martin meets Leora and foolishly gets engaged to both women, Lewis also contrasts the two women based on their conversation about education; Madeline mentions she works toward a graduate degree in English, to which the narrator quips that "she made it sound as though she were taking her earldom" (522). It is an understatement to read these passages and to not see the level of satire Lewis throws at the professions. Despite her own love of knowledge for knowledge's sake, Madeline contradicts her own values in praising Dr. Loizeau while deriding Gottlieb. Comparing the academic degree to an earldom also indicates a pointed joke that cultural capital does not equal economic capital, even if it distinguishes the professional classes from the lower ones. Madeline's role in the novel thus functions to create a sense of conflict between Martin the scientist versus Martin the aspiring professional. 
Martin's first wife Leora serves as his companion for most of the novel, and she operates as the primary source of encouragement for Martin to become a great scientist rather than professional. The novel goes out of its way to characterize Leora as a more down to earth woman who, after growing up in the small, narrow-minded town of Wheatsylvania, finds a companion with whom she can grow:

He found in her a casualness, a lack of prejudice, a directness, surprising in the daughter of Andrew Jackson Tozer. She was feminine but understanding; she was never Improving and rarely shocked; she was neither flirtatious nor cold. She was indeed the first girl to whom he had ever talked without self-consciousness. It is doubtful if Leora herself had a chance to say anything, for he poured out his every confidence as a disciple of Gottlieb

Leora proves to be the ideal companion to allow Martin to be true to himself; without her, Martin likely would not have taken the same path professionally. Her perceptions of him allow him to withdraw from material possessions and instead to seek the professional integrity to which he aspires. The point here, however, is that Martin cannot ascend higher up the ladder without a partner who also can rise with him. Because of his sense of class inferiority as an aspiring professional, he cannot meet his potential with Madeline though he can with Leora.

Leora is attracted to Martin because of his intellectual curiosity and search for truth; he represents to her the same self-reliance that it took for her to leave small Wheatsylvania to move to the city to become a nurse. Leora appreciates a sort of masculine self-reliance with the courage it takes to defy social conventions, and Lewis's narrator demonstrates this when Leora first sees Gottlieb, who was recently fired from Winnemac, on the streets: "Sandy, he's the greatest men I've ever seen! I don't know how I know, but he is! Dr. Silva is a darling, but that 
was a great man...there's the first man I ever laid eyes on that I'd leave you for, if he wanted me...he's like a brain walking" (583). Considering that Gottlieb is characterized in the novel as the intellectual savant who mentors Martin to become a great bacteriologist, it is no coincidence here that Leora is drawn to the same intellectual aura in Gottlieb as in Martin.

Although Leora is a good companion for Martin as she attempts to ascend to the middle class, their relationship together grows strained when Martin has ascended into the profession and its social circles. While living as a country doctor, Martin attempts to read European history to Leora, attempts to read Henry James's The Golden Bowl, and dives headfirst into Conrad's jungles (a Heart of Darkness reference); the narrator mentions that "He (Martin) was conscious of his own vocabulary" (638). The couple squabble throughout the novel as Martin wants Leora to rise to the occasion, such as when they have dinner together with the Duers, Martin's old classmate from Winnemac: "Dear, I'm awfully sorry. I went out this afternoon, I went out and had a facial massage, so as to look nice for you, and then I knew you like conversation, so I got my little book about modern painting that I bought and studied it terribly hard, but tonight I just couldn't seem to get the conversation around to modern painting" (761). Throughout these passages, Lewis again showcases the frivolity of the new professional class as they aspire to absorb cultural capital and to talk about such topics as The Golden Bowl or modern painting. Leora provides a sarcastic remark of sorts to indicate that she provides stability to the relationship more than appearances. Despite her attempts, a conflict between the couple only escalates in the novel, at least until Martin ascends to the height of his profession.

Joyce arrives in the last chapters of the novel as Martin attempts to use his phage in the Caribbean. Martin has an affair with her while leaving Leora behind so that she won't contract the plague; however, Leora catches it from her cigarette accidentally being contaminated in 
Martin's laboratory, causing her to die a horrible death alone. Joyce is the antithesis to Leora: she comes from old wealth as her family owns plantations in St. Hubert. Following their marriage after their return to New York, Martin and Joyce travel Europe together and even have a son. However, Joyce does not leave Martin ample time to pursue his scientific curiosities because of the social obligations they share, even going as far as to buy him a laboratory so he can work from home. Despite all of Martin's newfound wealth, he finds that a greater lack exists in their relationship than in his one with Leora regarding social standing. A rich patent lawyer scolds Joyce: "this Arrowsmith person may know all about germs, but he doesn't know a symphony from a savory" (950). With regards to Martin's newborn son, the narrator remarks that "Joyce worshiped him, and Martin was afraid of him, because he saw that this minuscule aristocrat, this child born to the self-approval of riches, would some day condescend to him" (947). Despite having all these luxuries in living with Joyce, Martin cannot find happiness even as he ascends to the height of his profession in marrying Joyce and in achieving social standing with his phage experiment. It takes the entire novel for Martin to realize that he cannot be true to his work or himself whilst worrying about the profession. With all said, Martin's relationships with women all parallel the social standing in which he finds himself at any given moment in the novel. In this way, the novel, like the realist texts surveyed in the previous chapter, incorporates romance as a device to anchor its larger political subtext of the exclusivity of the profession. Leora dies only to resolve the conflict that Dr. Arrowsmith needs cultural capital, which neatly ties together the novel's themes regarding professionalization.

\section{VI: The Novel's Ending: A Return to the Philosopher-Physician}

The novel's resolution ties the entire structure of the novel and its thematic underpinning together as Martin withdraws from his high-paying job and his rich wife to work alone with 
Terry Wickett on a lake. It is difficult not to see echoes of Twain's Huck Finn here: just as Huck strikes out for the territories after the novel's treatment of difficult themes like race, slavery, and rural Americans, so too does Martin strike out for the territory in an act of self-reliance so that he can practice his work. Both Martin and Terry agree that they can live cheaply and without distraction there whilst working on some sera that they can sell to physicians to pay the bills. The narrator remarks that Martin now works to improve his mathematics and physical chemistry, and Martin sees ahead of him "numerous inquiries into chemotherapy and immunity; enough adventures to keep him busy for decades" (962). Joyce accuses Martin of being a fanatic in her pointed final words: "You've left common sense. I am common sense. I believe in bathing. Good-by!" (963). Its final image is Martin and Terry on the lake in a boat, with Martin celebrating that he'll likely fail more than not in his newfound freedom of inquiry.

Just as with Twain's satiric project in Huck Finn, Lewis must resolve all these contradictory threads in some way. Throughout the novel, Martin traveled from position to position, realizing in turn that he could not escape the influence of money or political interests. He is stifled by the lack of academic freedom to pursue and refine his interests. In this way, this ending illustrates a call for a return to the philosopher physician; lost within the shuffle of medical professionalization have been people with inquisitive minds who challenge all assumptions. Emphasis on professional specialization, like Angus Duer as a surgeon, limits the ability for innovation. While Martin's professional reputation for his article about the Caribbean phage is celebrated, Martin knows that his work was not science in its true spirit.

As mentioned in the introduction, Leo Marx's analysis of Twain's ending proves useful in discerning how Lewis's novel finishes its engagement with the realist form. The idea of formal unity and symmetry is disposed of in both Twain and Lewis's text to showcase the 
unreality of realism. Martin does not get a neat ending as he never finds a niche in the profession that he can carve; instead, he finds himself as an independent scholar who attempts to thrive outside the profession's boundaries. We also see the idea of satiric realism with the novel's end. Lewis's novel functioned as a censuring of the entire medical profession, and it did not leave any sense of optimism that the profession will change as Martin withdraws from it entirely. Unlike classical satire, where the problem tends to neatly resolve itself, nothing is healed by novel's end, and the rift between the profession and now its innovators is insurmountable. Because Lewis reduces almost everything to absurdity, the mainline profession, country doctors, and public health officials to name a few, the novel leaves little hope for medical advancement unless scientists are given the freedom to pursue research without political pressures thwarting their progress.

The ending of Arrowsmith thus resolves this study of medical professionalization and American literature's treatment of it from the time range of this dissertation ranging from circa 1830-1930. Just as the Jacksonian Americans feared the philosopher-physicians for not having enough regard for the patient in its literary representations of the overreaching scientist, now a call for the return of the philosopher-physician, the same figure chillingly represented in the gothic mode who resembles a scientist more so than a healer, exists as doctors now struggle to innovate in a profession that is risk-adverse due to the profession's emphasis on prestige and its place in American life. In a way then, Martin's acceptance of Gottlieb's philosophy that innovation sometimes comes at the expense of the patient harkens back to representations like Hawthorne's Rappaccini or Chillingworth. While American medicine undoubtedly was in better shape at the end of this time frame than at the beginning, it now will take a scientist with a philosopher's spirit to pave the way to the future 


\section{Notes}

1. Regarding the De Kruif link, see HM Fangerau's “The Novel Arrowsmith, Paul de Kruif (1890-1971) and Jacques Loeb (1859-1924): A Literary Portrait of 'Medical Science” and James M. Hutchisson's article "Sinclair Lewis, Paul de Kruif, and the Composition of Arrowsmith."

2. For the idea that Howellsian realism seeks narrative symmetry, see Cynthia Davis's Bodily and Narrative Forms: The Influence of Medicine on American Literature, 1845-1915,pg. 100.

3. Thackeray only receives a brief mention in Matz's book seeing how his era isn't the focus. Matz does provide an illuminating quote from Thackeray's 1852 lecture "Charity and Humor" that identifies him as a satiric realist: "I cannot help telling the truth as I view it, and describing what I see...To describe it otherwise than it seems to me would be falsehood in that calling in which it has pleased Heaven to place me; treason to that conscience which says that men are weak; that truth must be told; that fault must be owned' (qtd in Matz.28). Thackeray is among the writers listed in Lewis's text as he is a writer Madeline admires but has not read in many years.

4. In addition to my explanation of the Flexner Report in previous chapters, see Lynne Miller and Richard Weiss's article "Medical Education Reform Efforts and Failures of U.S. Medical Schools, 1870-1930."

5. See Leo and Miriam Gurko's 1943 article "The Two Main Streets of Sinclair Lewis" where they read Martin favorably against all the characters the work satirizes, noting that Lewis satirizes them without "the smallest trace of personal liking or sympathy for their exponents" (290). See also Charles Rosenberg's "Martin Arrowsmith: The Scientist as 
Hero". This strand also shows up in recent commentary on the novel, such as Russell Gollard's editorial “The Tragedy of Martin Arrowsmith: A Physician's Perspective.”

6. Frederick Carpenter's article "Sinclair Lewis and the Fortress of Reality" discusses the aesthetic implications of Lewis's satire, arguing that Lewis's work was negatively affected when he tried to dabble in other modes later in his career; however, he argues that Arrowsmith is when Lewis was at his peak aesthetically and thematically. On the other hand, Bloom disdained Arrowsmith, noting that he taught it to students with "subdued loathing." He read Arrowsmith as an idealistic morality tale, a lesser work compared to the likes of Emerson, Whitman, and Thoreau as a romance with allegorical undertones (3), and he reads the novel's ending as a retreat into the woods in the same structure as Walden.

7. Augspurger argues that the emerging new class of professionals-intellectuals, scientists, engineers, business managers, and others—received the status because of "advanced education, scientific training, and professional organization." He contends that a small subset of 'adversary' professionals rejected the bureaucratic ways the professions developed, believing that individual genius was then stifled (85). He applies this argument to Arrowsmith, reading Martin as one of these 'adversarial professionals.'

8. See Yeonsik Jung's two articles: "The Immunity of Empire: Tropical Medicine, Medical Nativism, and Biopolitics in Sinclair Lewis's Arrowsmith" and "The Rockefeller Institute and American Imperialism in Sinclair Lewis's Arrowsmith."

9. It should again be mentioned that biographical critics have read Gottlieb as a fictionalstand in for Jacques Loeb in Paul De Kruif's roman-a-clef, so in this reading, if we were to 
accept this premise, Loeb would be the ideal scientist that stands above other scientists and physicians more concerned with the profession.

10. In a short article "Teaching Arrowsmith," Sally Parry mentions how her students gravitated toward feminist criticism in their discussions. One of her students "thought Martin loved Leora because of her simplicity and unconditional support of him, and that he only criticized her when he felt his status was threatened in society because his wife wasn't socially presentable" and another "thought that Leora was the woman behind the great man and was very satisfied by this role (4). Another contended that "Martin's relationships with Joyce and Madeline were doomed to fail because their language emasculated him and took away both his linguistic and male power.” Another paper read Leora as fulfilling her part in marriage by allowing Martin time to work. Another student read Joyce, Martin's high-class wife in the last chapters of the novel, as a strong female character who was depicted as annoying since she was portrayed from a man's point of view. While none of these arguments have been developed beyond undergraduate papers, these thesis statements helped me to consider the role Lewis's women played in his interrogation of social class and the profession. Parry's article "The Changing Faces of Sinclair Lewis' Wives" also examines the role of women in Arrowsmith; Perry surveys many early Lewis novels and reads the characters biographically through Lewis's relationships with women in his life. Parry particularly reads Joyce as resembling Grace, Lewis's first wife, and Martin leaving her to pursue medical research parallels Lewis leaving Grace to work on Elmer Gantry. 


\section{Conclusion: Contemporary American Medical Debates \& Literary Form}

This dissertation's historical trajectory ended with allopathy regaining its elite authority as states again passed medical licensing laws, yet a profound sense of skepticism lingered as Lewis satirized how much the individual genius could not thrive within a profession designed to protect its interests over that of medical advancement. This skepticism about the medical profession has lingered throughout the decades as the unique tension between democratic medicine versus the undemocratic nature of the profession persisted. Today, the debates about the medical profession concern the extreme rises in cost due to a number of factors ranging from bureaucratic overhead to the greed of corporate entities like big pharmaceutical companies, and as a result, literary representations about medicine have adapted with the times.

Something that has changed since the nineteenth-century is the proliferation of medical dramas through film and television. It is a safe assumption that most outsiders then could only peek through the curtain at the profession through medical fiction or nonfiction. The importance of reading all the writers surveyed throughout this dissertation thus cannot be overstated as that is how many Americans then conceptualized their political opinions about physicians. In an age of widespread political debate about issues like universal healthcare coverage, films and television dramas about the medical profession have grown extremely popular. Almost every major television network has a successful medical drama, and it would prove a daunting task to survey them all. This dissertation's work in tracing nineteenth-century literary representations of medical professionalization with issues of literary form can provide context on a number of current representations as the structures and plots of nineteenth-century fiction remain in the cultural consciousness. A number of examples permeate the airwaves today that have roots that 
can be traced to nineteenth-century medical literature within the gothic, realist, naturalist, and satiric modes.

Most medical dramas existing today owe some debt to $E . R$, and we can trace the roots of this show to the works of American Realism involving medicine. In 1994, Michael Crichton, author of Jurassic Park, created this hit show that ran for fifteen straight seasons on NBC; according to a synopsis of the show on the Internet Movie Database, ER centers on "another day in the ER, from the exiting to the mundane, and the joyous and the heart-rending. Frenetic pacing, interwoven plot lines, and emotional rollercoasting is used to attempt to accurately depict the stressful environment found there." This description suggests that ER had realistic tendencies in showing the everyday affairs of a Chicago-based hospital; furthermore, much of its plot hinged on melodrama about the doctors' lives, including their romances along with the bonds developed with patients and each other. Some plots even included the drama of aspiring medical students learning the trade on their apprenticeships at the hospital following medical school; this included the struggles of female medical students. This show's look into the everyday affairs of the ER combined with character melodrama echoes back to the realistic novels of Howells, Phelps, and Jewett, where their heroines all must navigate their place in the profession alongside their relationships.

Doctor Quinn, Medicine Woman was another hit drama in the 1990s that starred Jane Seymour as a woman entering the profession in the latter nineteenth-century. This show, running for six seasons in the 1990s, featured the aforementioned Doctor Quinn moving from Boston to a small town in Colorado, and much of the drama centers on how Quinn strives to be accepted as a female practitioner in the American West. Like the realist novels of Howells, Phelps, and Jewett, much of the plot also centered on a marriage plot as multiple suitors competed for the affection 
of Doctor Quinn. Three seasons into the show, with the culmination of an arc resulting in the marriage of Doctor Quinn to an outdoorsy character, Byron Sully, Seymour joked of her character that "Dr. Quinn is the oldest living virgin on TV" but also anticipates how the new marriage will add an entire dynamic to the show as Quinn must now navigate medical practice with relationships (Walstad). This show embodies the same thematic underpinning that informed the nineteenth-century realists; Dr. Quinn reads mostly like Jewett's A Country Doctor in that she thrives within her profession without needing anyone to help her, though the show takes it a step further by dramatizing the tension between professional duty and marital obligations. The show blends realism with the Western, and it also serves as an anomaly as a successful Western show that thrived in the 1990s considering the genre had long been out of fashion by then. In the decades since the show ended, it remains popular as it is available via streaming as well as syndicated as wholesome family entertainment on venues like the Hallmark Channel. The marriage plotlines that informed the American Realists' engagement with who could enter the medical profession thus continues today. Networks continue to evolve the formula: a new show on CBS, "Carol's Second Act," showcases the struggle a woman in her 50s faces as a medical intern. As a dramatic comedy, the show represents the conflict this has on a nontraditional student, giving the show both a gendered and an ageist layer for points of conflict.

The gothic doctors from the likes of Hawthorne and Poe who hunger for knowledge or profit also influence contemporary literature and film. Beyond countless adaptations of Frankenstein, Lovecraft's "Herbert West, Reanimator" was adapted into a trilogy of films in the 1980s and early 1990s. Those films all display the overambitious scientist character arc and the destruction it causes as West reanimates corpses but they all turn murderous following the reanimation. The second season of American Horror Story is set at an asylum where a doctor 
performs grisly experiments on patients, most of whom are women. The gothic drama Penny

Dreadful features Frankenstein making another creature after his first one, this time as a beautiful person, until the second creature is murdered by the Creature in his vengeance.

Frankenstein then creates a bride for the Creature, only to fall in love with her himself; the bride, upon gaining autonomy after discovering how she was mistreated by men in her past life, rejects both creator and monster and instigates a feminist revolution. The political implications of the gothic mode in these examples resonate today; the mode excels at representing the social anxieties of modern Americans, but it remains politically ambivalent in representing the problem while not necessarily endorsing one or the other.

It would be negligent not to mention Thomas Harris's Hannibal Lecter novels in conversation with Hawthorne and Poe's gothic doctors. These texts characterize "Hannibal the Cannibal" as a brilliant psychologist at the top of his profession, and he uses his skills for psychoanalyzing patients to fulfill his own curiosity in playing mind games with the likes of Will Graham or Clarice Starling. Lecter preys on his patients whom he finds repulsive and rude, eating them for their transgressions. Furthermore, Lecter, a Renaissance man, is an expert physician who publishes in psychological medical journals, yet he abuses his power over those he treats. In The Silence of the Lambs, Lecter forces Clarice Starling to participate in psychoanalysis with him in exchange for clues on a serial murderer, Buffalo Bill, who was one of Lecter's former patients. Buffalo Bill had a timeline from abduction to death in his pattern for killing women, so the clock was ticking on Starling solving the case. Lecter delights in pushing Starling to understanding herself despite the fact that the clock was ticking in solving the case. Harris employs gothic techniques to illustrate Lecter's ruthlessness in his overzealousness as a physician, most notably his cold, calculating gaze. With regards to medical professionalization, 
these book represent again the horrors of the philosopher-physician as he cares more about his hubris than anyone else. Lecter relishes in exposing the secrets of the human psyche, and in large part this is due to his egotistical desire to be the smartest man in the room. While the Lecter texts are more gruesome than nineteenth-century representations, the root of his character type traces back to those overzealous doctors.

Hints of American Literary Naturalism also continue in medical dramas today. The 2004 film John $Q$ has much in common with American literary naturalism as uncaring and indifferent social forces set out to destroy the protagonist of the film, John Quincy's, son Mike who suffers from a rare heart condition causing him to need a transplant. Half of the film focuses on John struggling to find ways to help Mike while his HMO health coverage denies him treatment as the price of treatment is too costly; the film gives a number of $\$ 250,000$ in the film, with a $\$ 75,000$ down payment to get him on the organ transplant list. John, thinking he has good insurance, sees his coverage reduced at work when he is relegated to a part time employee from a full-time one. John, played with great emotion by Denzel Washington, engages with multiple medical professionals at the hospital, including a heart surgeon, Dr. Raymond Turner, played by James Woods, along with the hospital administrator, Rebecca Payne, played by Anne Heche. In one scene, Dr. Turner and Rebecca Payne sit down with John and his wife Denise to discuss options. Dr. Turner and Ms. Payne coldly tell the parents that their best option would be to medicate Mike as he will die without the transplant, which could be a risky operation, along with being an option they can't afford. After John asks Dr. Turner what he would do if it was his son, Dr. Turner affirms that he would do the transplant. A number of tropes surveyed across this dissertation show up in this scene. Ms. Payne observes the parents with a cold, emotionless gaze, and she displays no empathy for them as she delivers the prognosis. She looks extremely 
uncomfortable and inconvenienced when the parents display emotion. Furthermore, a class difference is made clear as well when Dr. Turner confirms that if it was his child, the option to medicate for pain until the moment of death would not be on the table. This scene anchors most of the film's first half as John finds that he cannot raise enough money even with the help of his local community.

The film's second half showcases John's willingness to confront the indifferent medical profession with the only way he can. When the hospital plans to disconnect Mike from his medications, as the family can no longer afford it, Denise demands that John do "something" to take control of the situation, so he goes to the hospital with a gun and takes the emergency room hostage. John demands that he will not let everyone go until the hospital does something for his son. Much of the drama then centers around the police failing to negotiate with John, even sending a SWAT team in to kill him. Most of the scenes in this half of the film center on the hostages siding with John in his struggle. In one scene, the patients deride Dr. Turner claiming that he follows the "hypocritical oath" since HMO health insurance pays doctors to treat patients as little as possible to keep costs at a minimum. John ultimately offers to kill himself since his heart would be a compatible match for his son, and he forces Dr. Turner to perform the operation despite his obvious ethical objections. Right before this dramatic moment happens, Ms. Payne learns that a new heart is available, and she offers to provide charity care because John's sympathetic story was being broadcasted by national news outlets. The film ends with Mike, healthy after his surgery, watching John being taken to prison after his criminal trial.

Despite facing uncaring social forces, John manages to take a stand against them and succeeds; however, the ending exposes injustice as John will miss being a parent for his son who has a new lease on life. The film maintains the same rhetorical fervor as those texts of American 
naturalism dealing with medical topics as the movie takes up the topic without a great deal of subtlety; it also romanticizes John to the point that all but one hostage testifies on his behalf in court; nonetheless, he now serves a prison sentence for testing the system in such a blatant way. The combination of a political tone combined with melodrama is reminiscent of American literary naturalism in this film; no matter what John does, he cannot defeat the indifferent system that does not act in the patient's interest. The main divergence from the form is the fact that John's son is healed, giving the film a happy ending. However, the system destroys John for a crime he commits against it. In this way, we thus see a current example of an American literary form taking shape.

We can see satiric works in current dramas as well that also have some roots within realism. Nip/Tuck was a medical drama that took Americans by storm from 2003 to 2010. The show focused on the lives of two Miami plastic surgeons, Dr. McNamara and Dr. Troy, whose stormy personal lives and exorbitant lifestyles become the show's focus. Broadcasted on a cable channel, FX, rather than a network, this show was designed to create shock more than anything else; it has been called softcore pornography due to its lavish and frequent sexual content. Carina Chocano of the Los Angeles Times calls the show "a distinctly late $20^{\text {th }}$, early $21^{\text {st }}$ century kind of horror" as "the show's outwardly cool, collected main characters spend much of their time beating down their bubbling ids and fighting back powerful surges of guilt." Chocano argues that sunny Miami has become the new gothic setting full of soul-sucking dread as the patients depicted on the show strive for perfection in their fight against getting older. The show does not paint either doctor in flattering ways; both doctors do not regard the patient's interests as much as their own; the doctors even have sexual relationships with their patients. The show's characters are so outlandish and ridiculous that it is difficult not to see the satiric elements 
present as the show casts a mirror on American society for wanting perfection when the doctors themselves are monsters. The show feels like a modern reading of Hawthorne's “Dr. Heidegger's Experiment" through a blend of satiric and gothic elements as countless patients go to Dr.

Heidegger looking for the Fountain of Youth. The sheer amount of excess in the way the show tells its story fully situates it as satire. Nip/Tuck is grounded in some reality though. One element the show was praised for was its graphic depictions of plastic surgery operations; in a review of the show, Scott Pierce says Nip/Tuck's surgeries are so stomach-churning that the gore "makes $E R$ look like Barney in comparison.” Reading this show through the lens of Lewis's satiric realism in Arrowsmith is thus a useful way of making sense of a popular culture phenomenon that lasted a full decade.

With the popularity of the medical humanities in recent years, it will be important to extend the conversation this dissertation espouses as the medical profession's ethos is being called to question by Americans who distrust scientific authorities. As noted in this conclusion, depictions of the American medical profession that exist within the gothic, realistic, and naturalist mode persist even if they have evolved slightly from the earlier versions, and with the popularity of medical fiction and drama, scholars would be wise to pay more attention to unpacking problems of form in them. This project has sought to unify discussions of form with greater attention to historicity as the latter has not been prioritized as much with the New Historicism's waning popularity, or at least with the profession assimilating the New Historicism's basic tenets into other critical lenses. Combining attention to form with historicity allows for a more informed literary study that can also help other fields like bioethics, allowing for the humanities to thrive in tandem with the ever-increasing trend toward STEM education in the modern university climate. This work also serves as a reminder on the importance of a strong 
medical profession that maintains a sense of transparency with the American public, which would be a great contrast from the profession in the nineteenth-century. Surveying literature on the medical profession with the historical tendencies of the profession also can allow for an expansion of the canon as greater attention can be spent on authors like Howells, Jewett, and Lewis, whose medical works do not receive as much attention as their others. In sum, future studies of literature will benefit from historical examinations in conjunction with other critical lenses, allowing for work that informs the present as much as the past. 


\section{Works Cited}

Athanassakis, Yanoula. Environmental Justice in Contemporary US Narratives. Routledge: 2017.

Augspurger, Michael. 'Sinclair Lewis' Primers for the Professional Managerial Class: 'Babbitt' 'Arrowsmith,' and 'Dodsworth.' The Journal of the Midwest Modern Language Association, vol. 34, no. 2, Spring 2001, pp. 73-97.

Benson, Jackson. John Steinbeck, Writer. Penguin, 1984.

Bernstein, Stephen. "Form and Ideology in the Gothic Novel." Essays in Literature vol. 18, no. 2, Fall 1991, pp. 151-65.

Bloom, Harold. "Introduction." Bloom's Modern Critical Interpretations: The Grapes of Wrath. 1988. Chelsea House Publishing: 2006.

---. "Introduction.” Sinclair Lewis: Modern Critical Views, edited by Howard Bloom, Chelsea House Publishers, 1987, pp. 1-4.

Botting, Fred. Gothic. New York: Routledge, 1996.

Browner, Stephanie. "Reading the Body: Hawthorne’s Tales of Medical Ambition." Philadelphia: University of Pennsylvania Press, 2006. 44-69.

Carnegie, Andrew. "The Gospel of Wealth." 1889. Carnegie.org, n.d., https://www.carnegie.org/about/our-history/gospelofwealth/

Carpenter, Frederic. "Sinclair Lewis and the Fortress of Reality." College English, vol. 16, no. 7, Apr. 1955, pp. 416-231.

Cerulli, Anthony, and Sarah Berry. "Nathaniel Hawthorne's Warring Doctors and Meddling Ministers." Mosaic: A Journal for the Interdisciplinary Study of Literature vol. 47, no. 1, 2014, pp. 111-28. 
Cervetti, Nancy. "S. Weir Mitchell and his Snakes: Unraveling the 'United Web' and Woof of Popular and Scientific Beliefs. Journal of Medical Humanities vol. 28, no. 3, Sept. 2008, pp. 119-33. MLA International Bibliography.

Chocano, Carina. “The Miami Macabre of 'Nip/Tuck”” Latimes.com, 29 June 2004, https://www.latimes.com/archives/la-xpm-2004-jun-29-et-chocano29-story.html

Church, Joseph. "The Healing Arts of Jewett's Country Doctor." Colby Quarterly vol. 34, no. 2, 1998, pp. 99-122.

Cohen, Stephen. "Between Form and Culture: New Historicism and the Promise of a Historical Formalism." Renaissance Literature and its Formal Engagements, edited by David Rasmussen, Palgrave Macmillan, 2003, pp. 17-41.

Colacurcio, Michael. The Province of Piety: Moral History in Hawthorne's Early Tales. Durham, NC: Duke UP, 1995.

Cowley, Malcolm. “'Not Men': A Natural History of American Naturalism.” The Kenyon Review vol. 9, no. 3, Summer 1947, pp. 414-35.

Crichton, Michael, creator. ER. NBC Network, 1994-2009.

Dary, David. Frontier Medicine: From the Atlantic to the Pacific, 1492-1941. New York: Vintage, 2008.

Davis, Cynthia. Bodily and Narrative Forms: The Influence of Medicine on American Literature, 1845-1945. Stanford UP: 2000.

DeMott, Robert. “'A Great Black Book: East of Eden and Gunn's New Family Physician." Steinbeck's Typewriter: Essays on his Art. The Whitson Publishing Company: 1997, pp. $55-74$. 
Dent v. West Virginia. 129 U.S. 114. United States Supreme Court. 1889. https://supreme.justia.com/cases/federal/us/129/114/case.html

Dolezal, Joshua. "The Medical Palimpsest of The Scarlet Letter: An Interdisciplinary Reading." Medical Humanities vol. 31, 2005, pp. 17-22. MLA International Bibliography.

Donaldson, Susan V. "Elizabeth Stuart Phelps, Realism, and Literary Debates on Changing Gender Roles." Realism and Its Discontents, Eds. Danuta Fjellestad and Elizabeth Kella, Blekinge Institute of Technology, 2003, pp. 87-111.

Dunn, L. Kerr. Mysterious Medicine: The Doctor-Scientist Tales of Hawthorne and Poe. Kent, OH: The Kent State University Press, 2016.

Eagleton, Terry. "Ideology and Literary Form.” Criticism and Ideology: A Study in Marxist Literary Theory. 1976. Verso, 2006, pp. 102-61.

Esposito, Mark. "J.P. Morgan and the Reverse Bailout that Saved the U.S." jonathanturley.org, 6. February 2011, https://jonathanturley.org/2011/02/06/j-p-morgan-and-the-reversebailout-that-saved-the-u-s/

Fangerau, HM. “The Novel Arrowsmith, Paul de Kruif(1890-1971) and Jacques Loeb (18591924): A Literary Portrait of 'Medical Science.'” Medical Humanities, vol. 32, no. 2, pp. $82-87$.

Flanagan, Maureen. America Reformed: Progressives and Progressivisms 1890s-1920s, Oxford UP, 2007.

Fulton, Valerie. "Rewriting the Necessary Woman: Marriage and Professionalism in James, Jewett, and Phelps." The Henry James Review, vol. 15, no. 3, Fall 1994, pp. 242-56. 
Furst, Lilian. "Halfway up the Hill: Doctresses in Late Nineteenth-Century American Fiction." Women Healers and Physicians: Climbing a Long Hill. University of Kentucky Press, 1999, pp. 221-38.

Gilman, Charlotte Perkins. "The Yellow Wallpaper." The Norton Anthology of American Literature Volume $C, 8^{\text {th }}$ ed, edited by Nina Baym \& Robert Levine, Norton, 2012, pp. $792-803$.

---. "Why I Wrote the Yellow Wallpaper." The Norton Anthology of American Literature Volume $C, 8^{\text {th }}$ ed, edited by Nina Baym \& Robert Levine, Norton, 2012, pp. 804.

Gollard, Russell. “The Tragedy of Martin Arrowsmith: A Physician's Perspective.” The Sinclair Lewis Society Newsletter, vol. 16, no. 1, 2007, pp. 7.

Gordon, Lynne. “Annie Nathan Meyer and Barnard College: Mission and Identity in Women's Higher Education, 1889-1950.” History of Education Quarterly vol. 26, no. 4, Winter 1986, pp. 503-22.

Gurko, Leo, and Miriam Gurko. "The Two Main Streets of Sinclair Lewis." College English, vol. 4, no. 5, Feb. 1943, pp. 288-92.

Hall, Deidre Dallas. Scientific Methods: American Fiction \& the Professionalization of Medicine, 1880-1940. 2010. The University of North Carolina at Greensboro, Ph.D dissertation.

Hawthorne, Nathaniel. “Dr. Heidegger's Experiment.” Nathaniel Hawthorne: Tales \& Sketches. New York: The Library of America, 1982, pp. 470-79.

---. "Rappaccini’s Daughter.” Nathaniel Hawthorne: Tales \& Sketches. New York: The Library of America, 1982, pp. 975-1005. 
---. "The Birthmark." Nathaniel Hawthorne: Tales \& Sketches. New York: The Library of America, 1982, pp. 764-80.

---. The Scarlet Letter. 1850. Nathaniel Hawthorne: Collected Novels. New York: The Library of America, 1983, pp. 115-345.

---. “The Haunted Quack.” 1831. Nathaniel Hawthorne: Tales \& Sketches. New York: The Library of America, 1982, pp. 49-60.

Heddendorf, David. “'The Octopus' in McTeague: Frank Norris and Professionalism.” Modern Fiction Studies vol. 37, no. 4, Winter 1991, pp. 677-88.

"History of the American Veterinary Medical Association." Avma.org, n.d, https://www.avma.org/about/history-avma

Hogle, Jerrold. "The Progress of Theory and the Study of the American Gothic." A Companion to American Gothic. Ed. Charles Crow. Blackwell, 2014, pp. 3-15.

Howard, June. Form and History in American Literary Naturalism. The University of North Carolina Press, 1985.

Howells, William Dean. "From Novel-Writing and Novel-Reading: An Impersonal Explanation." The Norton Anthology of American Literature, Volume C, $8^{\text {th }}$ Ed, Edited by Nina Baym and Robert Levine, Norton, 2012, pp. 905-07.

--. Dr. Breen's Practice. 1881. Produced by David Widger. Retrieved from Apple iBooks

Hughes. John. John Steinbeck: A Study of the Short Fiction. Twayne Publishers, 1989.

Hutchisson, James. "Sinclair Lewis, Paul de Kruif, and the Composition of Arrowsmith." Studies in the Novel, vol. 24, no. 1, Spring 1992, pp. 48-61. 
James, Henry. "From the Art of Fiction." The Norton Anthology of American Literature, Volume C, $8^{\text {th }}$ Ed, Edited by Nina Baym and Robert Levine, Norton, 2012, pp. 905-07. Jameson, Fredric. The Political Unconscious: Narrative as a Socially Symbolic Act. Kindle Ed., Cornell UP, 1982.

Jewett, Sarah. A Country Doctor and Selected Stories and Sketches. 1884. E-book, Apple iBooks John Q. Directed by Nick Cassavetes, Performances by Denzel Washington, Robert Duvall, James Woods, and Anne Heche, New Line Cinema, 2002.

Jung, Yeonsik. "The Immunity of Empire: Tropical Medicine, Medical Nativism, and Biopolitics in Sinclair Lewis's Arrowsmith." Literature and Medicine, vol. 34, no. 1, pp. 185-206.

---. "The Rockefeller Institute and American Imperialism in Sinclair Lewis's Arrowsmith." The Explicator, vol. 74, no. 2, pp. 83-87.

Kaplan, Amy. The Social Construction of American Realism. The University of Chicago Press, 1988.

Kluger, Jeffrey. “John Q: How Real is this Horror Story?” Time, vol. 159, no. 10, Mar. 2002, pp. 44-45.

Knight, Charles. "Satire, Speech, and Genre." Comparative Literature, vol. 44, no. 1, pp. 22-41.

Knight, Denise. "'All the Facts of the Case': Gilman's Lost Letter to Dr. S. Weir Mitchell.” American Literary Realism, vol. 37, no. 3, Spring 2005, pp. 259-77.

Lewis, Sinclair. Arrowsmith. 1925. The Collected Works of Sinclair Lewis, edited by Michael Meyer. E-Book, Apple iBooks.

Levinson, Marjorie. "What is New Formalism?” PMLA vol. 122, no. 2, pp. 558-69. 
Lingeman, Richard. Sinclair Lewis: Rebel from Main Street. Borealis Books: 2002.

Link, Eric Carl. The Vast and Terrible Drama: American Literary Naturalism in the Late Nineteenth Century. The University of Alabama Press, 2004.

Lovecraft, H.P. "Herbert West—Reanimator.” H.P. Lovecraft: Tales. Ed. Peter Straub. New York: The Library of America, 2005, pp. 24-54.

Koch, Charles. A History of Dental Surgery: Volume II: Dental Laws and Legislation, Dental Societies, and Dental Jurisprudence, 1910, archive.org, Accessed 31 December 2017, https://archive.org/details/historyofdentals01koch

Marx, Leo. "Mr. Eliot, Mr. Trilling, and Huckleberry Finn.” The American Scholar vol. 22, no. 4, pp. 423-440.

Matz, Aaron. Satire in an Age of Realism. Cambridge UP: 2010.

McParland, Robert. Citizen Steinbeck: Giving Voice to the People. Rowman \& Littlefield, 2016.

Meyer, Annie Natham. Helen Brent, M.D. 1892. Forgotten Books: 2015.

Michaels, Walter Benn. The Gold Standard and the Logic of Naturalism: American Literature at the Turn of the Century. University of California Press, 1987.

Miller, Lynn, \& Robert Weiss. "Medical Education Reform Efforts and Failures of U.S. Medical Schools, 1870-1930." Journal of the History of Medicine and Allied Sciences vol. 63, no. 3, July 2008, pp. 348-87.

Mitchell, Silas Weir. The Autobiography of a Quack. 1867. Createspace Independent Publishing Platform: 2017.

Murison, Justine. "Quacks, Nostrums, and Miraculous Cures: Narratives of Medical Modernity in the Nineteenth-Century United States." Literature and Medicine vol 32, no. 2, pp. 419440. 
Murphy, Ryan, creator. Nip/Tuck. FX Networks, 2003-10.

Neuman, Johanna. Gilded Suffragists: The New York Socialites who Fought for Women's Right to Vote. NYU Press: 2017.

Newlin, Keith. "The Documentary Stages of Naturalism." The Oxford Handbook of American Literary Naturalism, Edited by Keith Newlin, Oxford UP, 2011, pp. 104-117.

Norris, Frank. McTeague. 1899. $2^{\text {nd }}$ Ed, Edited by Donald Pizer, Norton, 1996.

Parry, Sally. "Teaching Arrowsmith." The Sinclair Lewis Society Newsletter, vol. 9, no. 1, 2000, pp. 2-4.

---. "The Changing Faces of Sinclair Lewis' Wives." Studies in American Fiction, vol. 17, no. 1, pp. 65-79.

Petrie, Paul. Conscience and Purpose: Fiction and Social Consciousness in Howells, Jewett, Chesnutt, and Cather. The University of Alabama Press, 2005.

Phelps, Elizabeth Stuart. Doctor Zay. 1882. The Feminist Press, 1987.

Pierce, Scott. 'FX's 'Nip/Tuck' is Hard to Take.” Deseret.com, 22 June 2004, https://www.deseret.com/2004/6/22/19835920/fX-s-nip-tuck-is-hard-to-take

Pizer, Donald. "Bad Critical Writing.” Philosophy \& Literature vol. 22, no. 1, April 1998, pp. 69-82.

Poe, Edgar Allan. "Berenice.” Edgar Allan Poe: Poetry and Tales. Ed. Patrick Quinn. New York: The Library of America, 1984, pp. 225-33.

---. "The Facts in the Case of M. Valdemar." Edgar Allan Poe: Poetry and Tales. Ed. Patrick Quinn. New York: The Library of America, 1984, pp. 833-42.

Pryce, Marjorie. "'I was Country when Country wasn't Cool': Regionalizing the Modern in Jewett's A Country Doctor.” American Literary Realism vol. 34, no. 3, Spring 2002, pp. 217-32. 
Puskar, Jason. Accident Society: Fiction, Collectivity, and the Production of Chance. Stanford UP: 2012.

Rasmussen, David. "Introduction: New Formalisms?" Renaissance Literature and its Formal Engagements, edited by David Rasmussen, Palgrave, 2002, pp. 1-17.

Reynolds, David. Beneath the American Renaissance: The Subversive Imagination in the Age of Emerson and Melville. Alfred A. Knopf, 1988.

Robinson, C. "Fighting Words: Polemics and Social Change in Literary Naturalism by Ira Wells (review)." Studies in American Naturalism, vol. 8 no. 2, 2013, pp. 257-59.

Rosenberg, Charles. "Martin Arrowsmith: The Scientist as Hero.” Sinclair Lewis: Modern Critical Views, edited by Howard Bloom, Chelsea House Publishers, 1987, pp. 41-50.

Sartisky, Michael. “Afterword.” Dr. Zay. The Feminist Press: 1987, pp. 259-321.

Scanlon, Lawrence. "Dental Questions in Frank Norris's Novel McTeague. Journal of the History of Dentistry, vol 50, no. 1, 2002, pp. 17-24.

Sellars, Charles. The Market Revolution: Jacksonian America, 1815-1846. New York: Oxford UP, 1991.

Shi, David. Facing Facts: Realism in American Thought and Culture, 1850-1920. Oxford UP, 1995.

“Silas Weir Mitchell.” Whonamedit.com, n.d., whonamedit.com/doctor.cfm/959.html

Steinbeck, John. The Forgotten Village. 1941. Penguin, 2009.

--. The Log from the Sea of Cortez. 1941. John Steinbeck: The Grapes of Wrath and Other Writings 1936-1941, Edited by Robert DeMott, Library of America, 1996, pp. 751-973. 
--. The Pearl. 1947. John Steinbeck: Novels 1942-52, Edited by Robert DeMott, Library of America, 2001, pp. 229-305.

--. “The Snake.” 1935. John Steinbeck: The Grapes of Wrath and Other Writings 1936-1941, Edited by Robert DeMott, The Library of America, 1996, pp. 48-57.

Stiles, Anne. "'The Intimate Language of Friendship with Men': Same-Sex Attraction in the Civil War Fiction of S. Weir Mitchell.” Literature and Medicine vol. 32, no. 1, Spring 2014, pp. 193-217.

Stoehr, Taylor. Hawthorne's Mad Scientists: Pseudoscience and Social Science in NineteenthCentury Life and Letters. Hamden, CT: Archon Books, 1978.

Stooke, David. The Portrait of the Physician in Selected Prose Fiction of Nineteenth-Century American Authors. Dissertation. George Peabody College. August, 1976.

Storey, Mark. "The Place of Medical Knowledge: Country Doctors." Rural Fictions, Urban Realities. Oxford UP, 2013, pp. 83-115.

Sullivan, Beth, creator. Dr. Quinn, Medicine Woman. CBS Networks, 1993-98.

Walstad, David. "Marriage==and Sex!==at Last In ‘Dr. Quinn' Season Finale.” Latimes.com, 10 May 1995, https://www.latimes.com/archives/la-xpm-1995-05-10-ca-64394-story.html

Wegener, Frederick. "Introduction.” A Country Doctor. Penguin: 2005, pp. vii-xxxviii.

---. "Marriage and the American Medical Woman in Dr. Breen's Practice. The Howellsian, vol. 10, no. 2, Fall 2007, pp. 4-9.

Wells, Ira. Fighting Words: Polemics and Social Change in Literary Naturalism. University of Alabama Press, 2013.

Whooley, Owen. Knowledge in the Time of Cholera. Chicago: University of Chicago Press, 2013. 
Wolfson, Susan. "Reading for Form.” $M L Q$ vol. 61, no. 1, pp. 1-16.

Woodward, Walter. "God's Secret": John Winthrop, Jr., Alchemical Healing, and the Medical Culture of Early New England.” Prospero's America. UNC Press, 2010, pp.160-209.

Ying-Li, Hsin. "For Love or Money: Courtship and Class Conflict in Howells' The Rise of Silas Lapham.”Studies in American Fiction, vol. 24, no. 1, Spring 1996, pp. 101-21. 